\title{
Revisiting the age and palaeoenvironments of the Upper Jurassic-Lower Cretaceous? dinosaur-bearing sedimentary record of eastern Spain: implications for Iberian palaeogeography
}

\author{
Sonia Campos-Soto ${ }^{1,2}$ - M. Isabel Benito ${ }^{1,2}$. Alberto Cobos $^{3} \cdot$ Esmeralda Caus $^{4} \cdot$ I. Emma Quijada $^{5}$. \\ Pablo Suarez-Gonzalez ${ }^{6} \cdot$ Ramón Mas $^{1,2} \cdot$ Rafael Royo-Torres $^{3} \cdot$ Luis Alcalá $^{3}$
}

Received: 28 January 2019 / Accepted: 5 April 2019 / Published online: 3 May 2019

(c) Universidad Complutense de Madrid 2019

\begin{abstract}
An integrated stratigraphic, palaeontological, palaeoenvironmental and palaeogeographical study of the traditionally considered Upper Jurassic-Lower Cretaceous dinosaur-bearing sedimentary record (DSR) of eastern Spain is accomplished for the first time. Several areas where dinosaur fossils are abundant (western Maestrazgo and South-Iberian basins) have been studied in detail. In all the areas, the DSR comprises a carbonate-dominated lower part (CLP), and an essentially siliciclastic upper part (SUP). Deposition occurred in a shallow-very shallow marine carbonate platform, laterally connected towards the $\mathrm{N}$ and $\mathrm{W}$ to coastal and alluvial environments. The overall upwards evolution is regressive with a transgresive episode at the uppermost part. The DSR includes deposits previously assigned, depending on the studied area, from the Kimmeridgian to the Barremian (locally even to the Aptian-Albian). However, ages obtained in this work from larger benthic foraminifera (LBF), demonstrate a Kimmeridgian-Tithonian age (locally Kimmeridgian-Early Berriasian?) for the DSR. These findings have important implications regarding the age of dinosaur fossils of these deposits, traditionally assigned to the JurassicCretaceous transition, or even to the Early Cretaceous, erroneously, and have necessitated a deep litho- and chronostratigraphic revision of the units previously established in the studied areas: new data indicate that the DSR is correlatable with deposits of the Villar del Arzobispo Fm and that the usage of the Aldea de Cortés and El Collado Fms, traditionally assigned to the Early Cretaceous, should be avoided. New data also reveal that the DSR should be correlated with other Kimmeridgian-Tithonian dinosaur-bearing deposits of Iberia, such as those of the Cameros Basin, Asturias and Portugal, and have encouraged a revision of the Iberian palaeogeography at that time. In fact, ages obtained from LBF agree with data provided by the systematics of dinosaurs, since dinosaur faunas of eastern Spain are similar to those of the other Late Jurassic Iberian areas, especially to those of the Lusitanian Basin.
\end{abstract}

Keywords Kimmeridgian-Tithonian $\cdot$ Larger benthic foraminifera $\cdot$ Shallow marine $\cdot$ Coastal wetland system $\cdot$ Verterbrates

\section{Resumen}

En este trabajo se realiza por primera vez un estudio multidisciplinar (estratigráfico, paleontológico, paleoambiental y paleogeográfico) del registro sedimentario del este de España que contiene abundantes fósiles de dinosaurio (DSR) y que tradicionalmente se ha asignado al Jurásico Superior-Cretácico Inferior. En concreto se han estudiado en detalle varias áreas de la Cuenca Suribérica y del oeste de la Cuenca del Maestrazgo en las que los fósiles de dinosaurio son más abundantes. En todas las áreas que se han estudiado, el DSR está formado por una parte inferior (CLP), esencialmente carbonática, y por una parte superior (SUP), esencialmente siliciclástica, que se depositaron en una plataforma carbonática somera o muy

Electronic supplementary material The online version of this article (https://doi.org/10.1007/s41513-019-00106-y) contains supplementary material, which is available to authorized users.

Sonia Campos-Soto

sonia.campos.soto@ucm.es

Extended author information available on the last page of the article 
somera, que estaba conectada lateralmente, hacia el norte y oeste, con ambientes costeros y aluviales. La evolución de estos sistemas a lo largo del tiempo fue, en general, regresiva, aunque se ha podido registrar en ambas cuencas un episodio transgresivo en la parte más alta del registro estudiado. Respecto a la edad, el DSR se ha asignado previamente a edades comprendidas entre el Kimmeridgiense y el Barremiense (o incluso localmente al Aptiense-Albiense). Sin embargo, las edades obtenidas en este trabajo a partir de macroforaminíferos bentónicos (LBF) demuestran que el DSR tiene una edad Kimmeridgiense-Titoniense y, localmente, Kimmeridgiense-Berriasiense Inferior?. Estos nuevos hallazgos tienen implicaciones importantes en cuanto a la edad de los fósiles de dinosaurio que contienen los depósitos estudiados, que tradicionalmente se han asignado, erróneamente, al tránsito Jurásico-Cretácico o incluso al Cretácico Inferior, y hacen necesaria la realización de una revisión litoestratigráfica y cronoestratigráfica de las unidades previamente establecidas, y definidas, en las áreas de estudio: los nuevos datos indican que el DSR es equivalente a los depósitos de la Formación Villar del Arzobispo, por lo que se debe evitar el uso de las Formaciones Aldea de Cortés y El Collado, que tradicionalmente se han asignado al Cretácico Inferior. Los nuevos datos también revelan que los depósitos del DSR se deberían correlacionar con los depósitos de edad Kimmeridgiense-Titoniense de otras cuencas de Iberia como las de Cameros, Asturias o Lusitánica que también contienen abundantes fósiles de dinosaurio, y esto ha hecho necesario revisar la paleogeografía de Iberia para el Jurásico Superior. De hecho, las edades obtenidas a partir de los LBF concuerdan con los datos procedentes de la sistemática de los dinosaurios, ya que las faunas de dinosaurios del este de España son similares a las de otras cuencas del Jurásico Superior de Iberia, y especialmente a las de la Cuenca Lusitánica

Palabras clave Kimmeridgiense-Titoniense $\cdot$ Macroforaminíferos bentónicos $\cdot$ Marino somero $\cdot$ Humedales costeros . Vertebrados

\section{Introduction}

Continental and coastal deposits of the Jurassic-Cretaceous transition are worldwide well-known because they may contain abundant dinosaur fossils (e.g. Weishampel et al. 2004); however, in many cases there are controversies about their age and their regional or even global correlations because of the lack or the scarcity of fossils with chronostratigraphic significance in many of these deposits. One of these examples is the Upper Jurassic-Lower Cretaceous sedimentary record of eastern Spain (western Valencia and eastern Teruel provinces; Figs. 1, 2), which is internationally renowned for its abundance of vertebrate fossil sites (tracks and bones) represented mainly by sauropod, theropod, thyreophoran and ornithopod dinosaurs (Ortega et al. 2006; Cobos et al. 2014; Campos-Soto et al. 2017a; Alcalá et al. 2018, and references therein). Among dinosaur taxa defined in eastern Iberia, those of sauropods included in the clade Turiasauria stand out, such as the largest dinosaur in Europe, Turiasaurus riodevensis (Royo-Torres et al. 2006) and Losillasaurus giganteus (Casanovas-Cladellas et al. 2001). Other remarkable dinosaurs defined in the studied area are the titanosauriform Galveosaurus herreroi (Sánchez-Hernández 2005; Barco 2009) and the basal macronarian Aragosaurus ischiaticus (Sanz et al. 1987; Royo-Torres et al. 2014), which was the first dinosaur to be named in Spain. Likewise, two ichnotaxa have been defined: Deltapodus ibericus and Iberosauripus grandis (representing a stegosaurid and a megalosaurid theropod trackmakers, respectively; Cobos et al. 2010, 2014, respectively).
However, there is controversy about the geological age of some of these fossil sites, as well as about the nomenclature, limits and age of the lithostratigraphic units that contain them and, thus, about correlations with other coeval dinosaur-bearing deposits. For example: (i) there is not agreement about the age and stratigraphic correlations of the unit that contains most of the dinosaur remains, the Villar del Arzobispo Formation (Fm); since the 90s it has been considered as Tithonian-Berriasian (e.g. Aurell et al. 1994; Mas et al. 2004), although a Kimmeridgian age has been demonstrated recently at least locally (Campos-Soto et al. 2016a, 2017a); (ii) there is not agreement on the age or on the nomenclature of the unit with Aragosaurus ischiaticus, assigned to ages as different as Tithonian-Berriasian (e.g. Royo-Torres et al. 2009, 2014) and Valanginian-Hauterivian (e.g. Canudo et al. 2012); (iii) the lithostratigraphic unit where the first dinosaur bones were described in the Valencia province, the Aldea de Cortés Fm, has been traditionally assigned to the Valanginian-Hauterivian (Mas et al. 2004 and references therein), whereas Campos-Soto et al. (2016a) have attributed the beginning of its deposition to an age not younger than Tithonian; (iv) deposits containing dinosaur fossils with Jurassic affinities in the Valencia Province, were included initially in the El Collado Fm, traditionally considered as Barremian in age, although later they were placed in the Jurassic-Cretaceous transition (e.g. Casanovas-Cladellas et al. 1999, 2001; Santisteban and Suñer 2002; Luque et al. 2005). Due to all these controversies there is no agreement on the definition and limits of the units where some of these fossils were found, nor in the lithostratigraphic and 

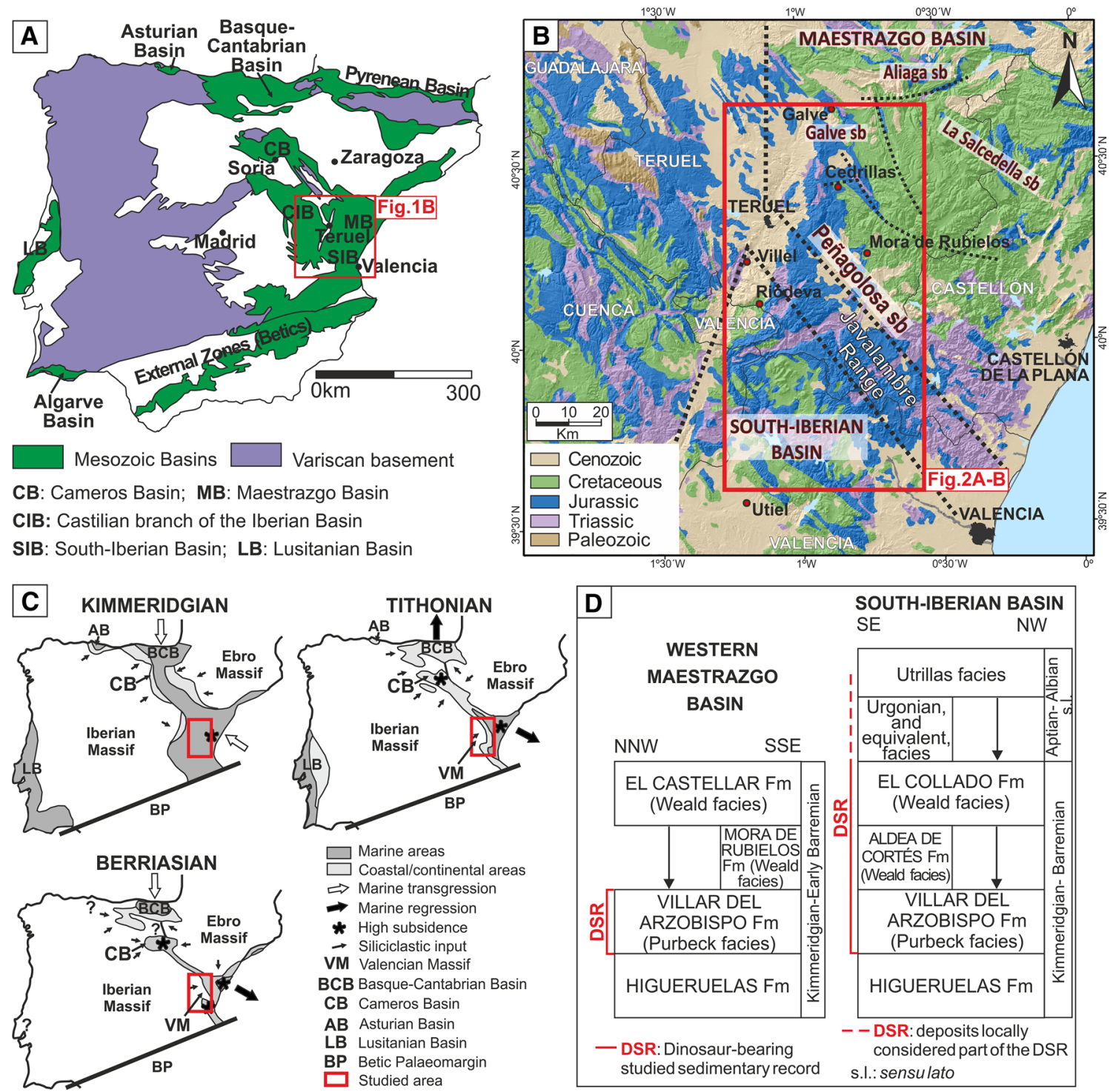

Fig. 1 a Location of the studied area in the context of the Mesozoic Iberian Extensional System (modified from Mas et al., 2004). b Geological map of eastern Spain, showing the location of the studied area (red square), and the limits between deposits of the Mesozoic basins cropping out in the area: the Maestrazgo Basin, and its sub-basins (modified from Salas and Guimerà 1996; 1997; Salas et al. 2001), and the South-Iberian Basin. c Palaeogeographic evolution of Iberia during the Late Jurassic-Early Cretaceous times (palaeogeography of eastern Spain: modified from Mas et al. 2004 according to

chronostratigraphic correlations with the dinosaur-bearing deposits of other Mesozoic basins of Iberia (Fig. 1a).

In this work, and for the first time, an integrated stratigraphic, palaeontological, palaeoenvironmental and palaeogeographical study of the Upper Jurassic-Lower Cretaceous sedimentary record that contains dinosaur fossils in eastern Spain is accomplished. New data obtained demonstrate a Late Jurassic age for most of the studied dinosaurbearing sedimentary record (DSR). Thus, and importantly, data published by Quijada et al. 2013; palaeogeography of the Asturian and Lusitanian basins: modified from Thierry et al. 2000a, b). d Lithostratigraphic units included in the studied dinosaur-bearing sedimentary record (DSR) or mentioned along the paper. The specific age of each unit is not included in the figure because of the controversies that exist about their nomenclature, limits and/or ages in many of the studied areas (see text, Fig. 3 and Table 1 of supplementary material for explanations and details)

ages of dinosaur fossils found in these deposits are revised accordingly.

Moreover, new data have allowed to revise the palaeoenvironments that dinosaurs inhabited (very shallow marine to coastal and alluvial) and have required us to establish new palaeogeographical correlations with other Upper Jurassic (Kimmeridgian-Tithonian) dinosaur-bearing deposits of Iberia, such as those of the Cameros, Asturian and Lusitanian basins, as well as to revise the palaeogeography of Iberia at that time. 


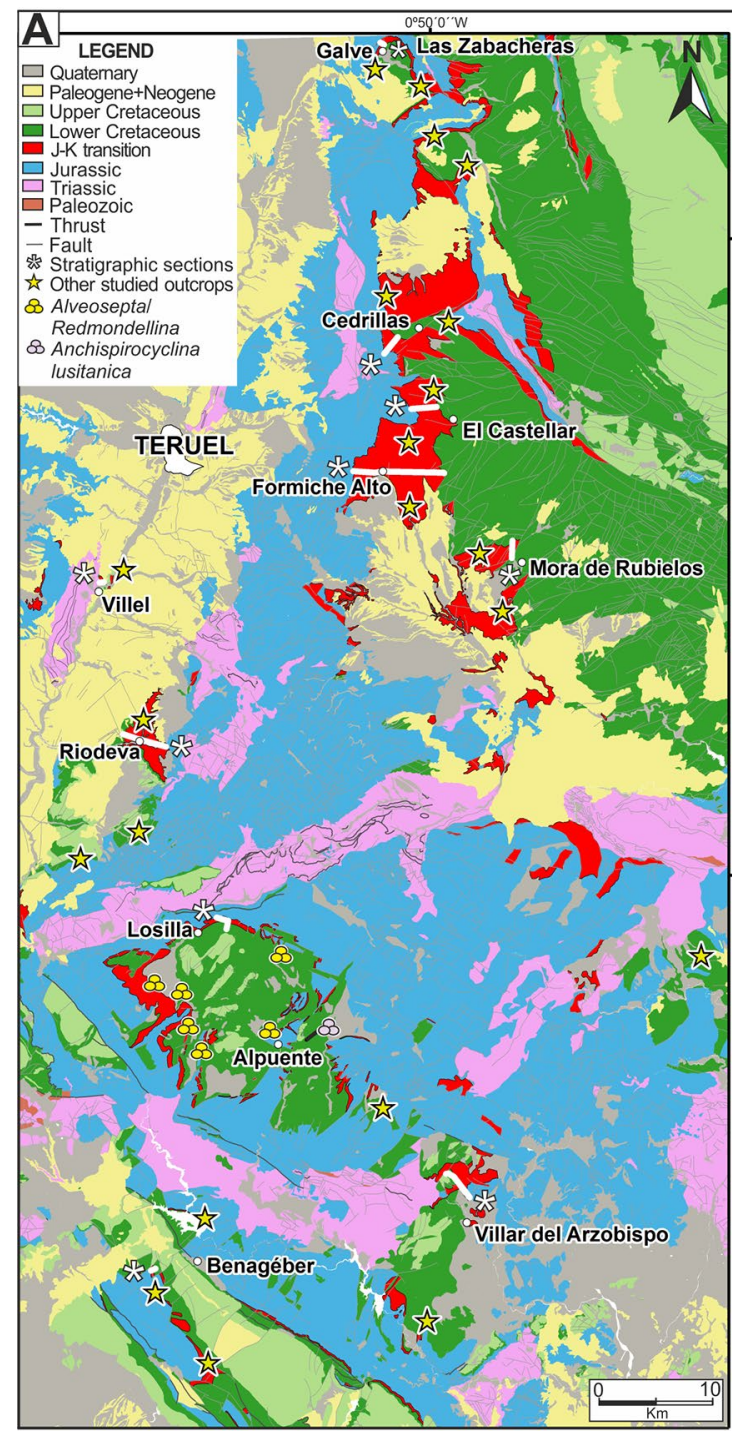

Fig. 2 Synthetic geological maps of the studied areas. a Geological map based on data provided by the literature. b Geological map performed after data provided in this work. Note the difference in the age of most of the Lower Cretaceous deposits to the south, in the SouthIberian Basin. Both maps indicate the location of the stratigraphic sections: Las Zabacheras (Galve), Cedrillas, El Castellar, Formiche Alto and Mora de Rubielos sections in the western Maestrazgo Basin,

\section{Geological setting}

The dinosaur-bearing sedimentary record studied in this work (DSR) was deposited in eastern Iberia, in the SouthIberian and western Maestrazgo basins (sensu Salas et al. 2001; Mas et al. 2004), located at NW Valencia and SE Teruel provinces (Figs. 1, 2). These basins were developed during the Late Oxfordian-Middle Albian in the context of the Mesozoic Iberian Extensional System and were inverted during the Cenozoic Alpine Orogeny (Salas and Guimerà 1997; Salas et al. 2001; Mas et al. 2004). During their

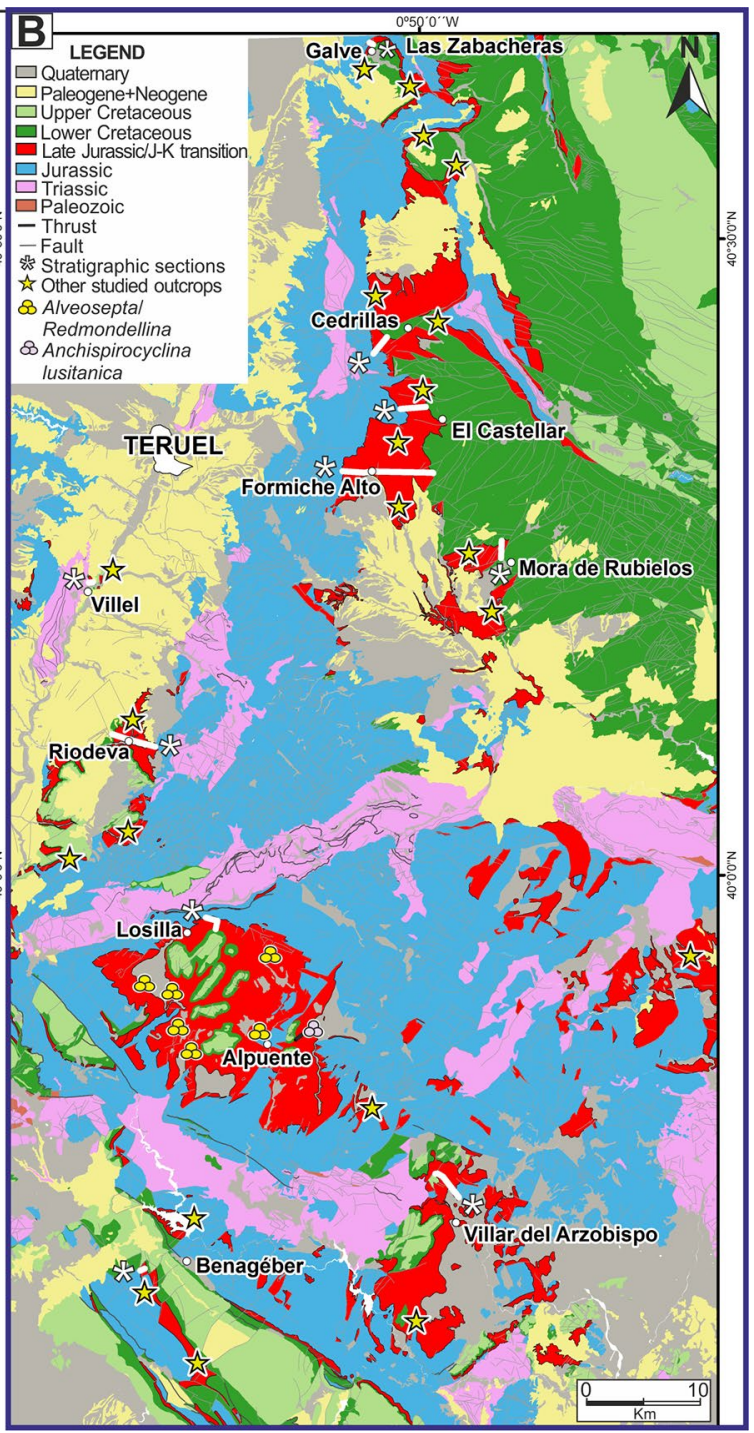

and Villar del Arzobispo, Benagéber, Losilla-Alpuente, Riodeva and Villel town sections, in the South-Iberian Basin. The map also shows the location of some of the isolated outcrops, from which important information has been obtained, such as the occurrence of the larger benthic foraminifera (LBF): Alveosepta/Redmondellina and Anchispirocyclina. These LBF have allowed to date properly the studied dinosaur-bearing sedimentary record (DSR)

extensional development, the emergent areas of Iberia were located to the west (Iberian Massif) and to the north (Ebro Massif), and the open marine areas were located (Fig. 1c; Salas et al. 2001; Mas et al. 2004) to the east and southeast of the studied areas (the Tethys realm) and to the north and northwest of Iberia (the Boreal realm). The South-Iberian and the Maestrazgo basins were separated by the emergent, NW-SE Valencian Massif (Fig. 1c; Mas and Alonso 1981; Mas et al. 2004), which was located where the "Sierra de Javalambre" is nowadays (Fig. 1b, c). Additionally, the Maestrazgo Basin is divided into several sub-basins (Salas 
and Guimerà 1996, 1997; Salas et al. 2001), and this study deals with deposits that contain abundant dinosaur fossils in the westernmost sub-basins, the western Peñagolosa and the Galve sub-basins (Teruel Province; Figs. 1b, 2).

The areas studied in the in the western Maestrazgo Basin crop out, along a N-S fringe located between Mora de Rubielos and Galve towns; the areas studied in the South-Iberian Basin (Teruel and Valencia provinces; Figs. 1b, 2) crop out along a NW-SE area located between Villel, Utiel and Villar del Arzobispo towns. Specifically, the DSR includes deposits traditionally attributed to the "Purbeck" or "Purbeckian" facies and, in some studied areas, also include deposits attributed to the "Weald" or "Wealden" facies (Gautier and Viallard 1966; Assens et al. 1973; González Lodeiro et al. 1975; Lazuen et al. 1977; Mas 1981; Mas and Alonso 1981; Vilas et al. 1982a; Díaz-Molina et al. 1984, 1985; DíazMolina and Yébenes 1987; Fezer 1988). Since the 80's, the "Purbeckian" deposits have been commonly included in the Villar del Arzobispo Fm (Figs. 1d, 3a), attributed to the Jurassic-Cretaceous transition (see details below). The Villar del Arzobispo Fm was defined in the South-Iberian Basin, in the Villar del Arzobispo area (Figs. 2, 3a), by Mas et al. (1984). The overlying "Wealden" deposits have been traditionally included in the Aldea de Cortés and/or El Collado Fms (Figs. 1d, 3a), defined as well in the South-Iberian Basin by Vilas et al. (1982a), in the Benagéber and LosillaAlpuente areas, respectively (Figs. 2, 3a), and assigned by these authors to the Early Cretaceous (Valanginian-Hauterivian and Late Hauterivian?-Early Barremian, respectively).

The Villar del Arzobispo Fm is a mixed siliciclasticcarbonate unit, which crops out extensively across the study area, and has been interpreted as regressive and deposited in an inner carbonate platform-lagoon that evolved upwards into siliciclastic alluvial or mixed siliciclastic-carbonate coastal and alluvial systems (e.g. Mas et al. 1984, 2004; Díaz-Molina and Yébenes 1987; Aurell et al. 1994; Luque et al. 2005; Santisteban and Esperante 2005; Santisteban and Santos-Cubedo 2010; Campos-Soto et al. 2016a, 2017a), although CamposSoto et al. (2016b, 2017a) have documented a transgressive episode towards the uppermost part of the unit in the western Peñagolosa sub-basin. Deposits of the Villar del Arzobispo Fm have been traditionally assigned to ages ranging from the Late Kimmeridgian to the Portlandian (in the sense of the Boreal realm Chronostratigraphy, BRC) by several authors, but since the 90s, the Kimmeridgian age was discarded and they were assigned to the Tithonian-Berriasian, in the sense of the Standard Chronostratigraphy (Fig. 3b, see Table 1 of supplementary material, T1SM, for references and details). More recently, deposits of the Villar del Arzobispo Fm have been dated as Kimmeridgian at the Benagéber area in the South-Iberian Basin (Campos-Soto et al. 2016a), and as Kimmeridgian-Tithonian in the western Peñagolosa sub-basin (Figs. 2, 3b; Campos-Soto et al. 2017a).
Fig. 3 a Stratigraphic sections logged in the studied areas (see the map to the left and Fig. 2 for location): $\mathbf{a}^{\prime}$ shows stratigraphic sections logged in the western Maestrazgo Basin; $\mathbf{a}^{\prime \prime}$ (in the opposite page), shows stratigraphic sections logged in the South-Iberian Basin. Sections show, in addition to the main sedimentary and palaeontological data (detailed in Table 1), the location of the samples, the LBF, and dinosaur tracks and bones: Las Zabacheras (samples ZB-C, ZB-CN, ZB3), Cedrillas (samples CE), El Castellar (samples CAS), Formiche Alto (samples SP), Mora de Rubielos (samples MO), in the western Maestrazgo Basin, and Villel town (samples VIL, VILE), Riodeva (samples RI, RI-CB, CA), Losilla-Alpuente (samples AS, $\mathrm{CO}, \mathrm{CO}-\mathrm{AO}, \mathrm{CO}-\mathrm{AL}, \mathrm{CO}-\mathrm{Ba}$, ALP-VILL), Benagéber (samples AC1, AC2) and Villar del Arzobispo (samples V-INF, V-SUP, VILLVILL), in the South-Iberian Basin. To the right of Las Zabacheras, Riodeva, Losilla-Alpuente and Benagéber sections, it is indicated the probable stratigraphic position within the DSR of the main dinosaur sites (see T3SM for details and references). To the left of each section there are some columns showing interpretations made by previous authors, who logged stratigraphic sections in the same places (or very close) as those made for this work; the rightmost column (with black letters) show interpretations made in this work (see legend for more details). b Kimmeridgian to Albian chronostratigraphy (modified from Gradstein et al. 2012), showing: to the left, in orange colour, the Boreal regional stages used before the Tithonian was formally adopted as a stage by the International Commission on Stratigraphy in 1990 (Gradstein et al. 2012); to the right, in blue colour, the Stages of the Standard Chronostratigraphy (Gradstein et al. 2012). In between, columns show the ages and the assignation to lithostratigraphic units proposed by previous authors in the different areas, if made; the equivalence to the informal units proposed in this work is shown in brackets. Columns with the ages and informal units proposed in this work are highlighted in blue colour for each studied area. See legend and figure caption in next pages (Fig. 3a)

The Villar del Arzobispo Fm conformably overlies the Higueruelas Fm, which mainly consists of oncolitic and oolitic limestone deposited in a mid- to inner-carbonate platform (e.g. Gómez 1979; Aurell 1990; Aurell et al. 1994; Campos-Soto et al. 2016a, 2017a). The Higueruelas Fm has been assigned to the Kimmeridgian (in the sense of the Boreal realm chronostratigraphy, BRC), or from the Kimmeridgian to the Portlandian, by several authors (Fig. 3b, see T1SM for details), and since the 90 s, it has been assigned to the Tithonian or to the Tithonian-Berriasian (e.g. Aurell 1990; Aurell et al. 1994, 2003, 2016; Bádenas et al. 2008-2009). However, according to Campos-Soto et al. (2016a, 2017a) and Pacios et al. (2018), the Higueruelas Fm would not be younger than Kimmeridgian, at least in the areas studied by these authors (Fig. 3a, b).

Deposits assigned to the Villar del Arzobispo Fm may be overlain by different units depending on the region, although all of them have been traditionally considered as Lower Cretaceous "Wealden facies" (Fig. 1d): (1) In the western Maestrazgo Basin they are overlain by deposits of the El Castellar Fm (Figs. 2, 3a), which is mainly composed of lacustrine carbonates (Canérot et al. 1982; Salas 1987) and is assigned to the Early Hauterivian-earliest Barremian by Martin-Closas (1989) based on charophytes or to the Late Valanginian-Early Barremian based on sequence 


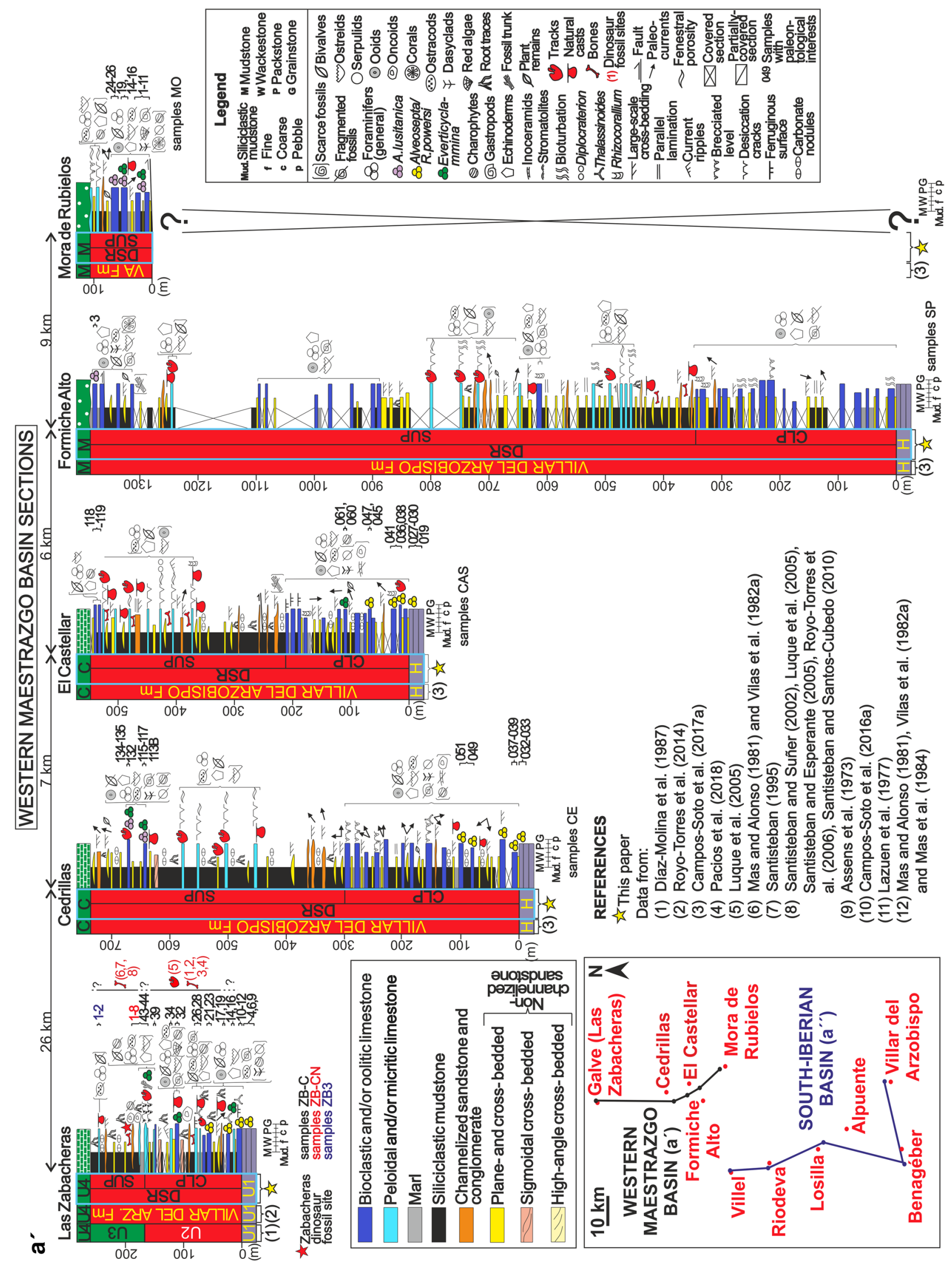




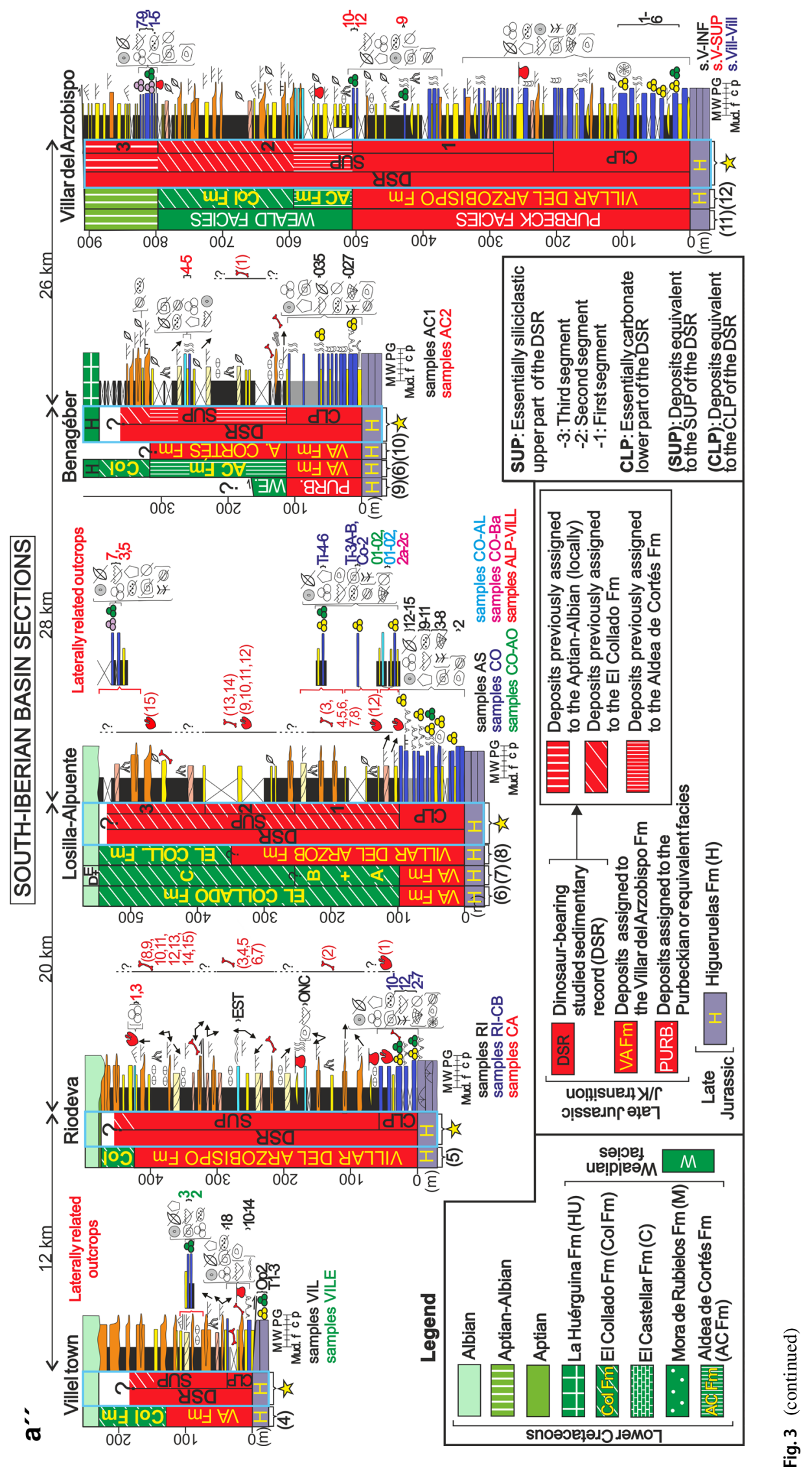




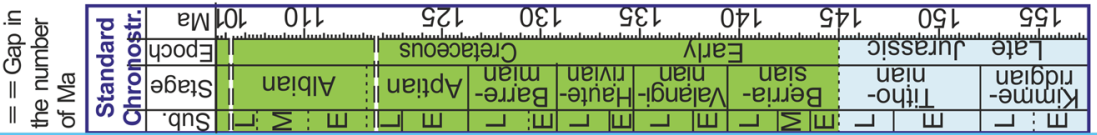

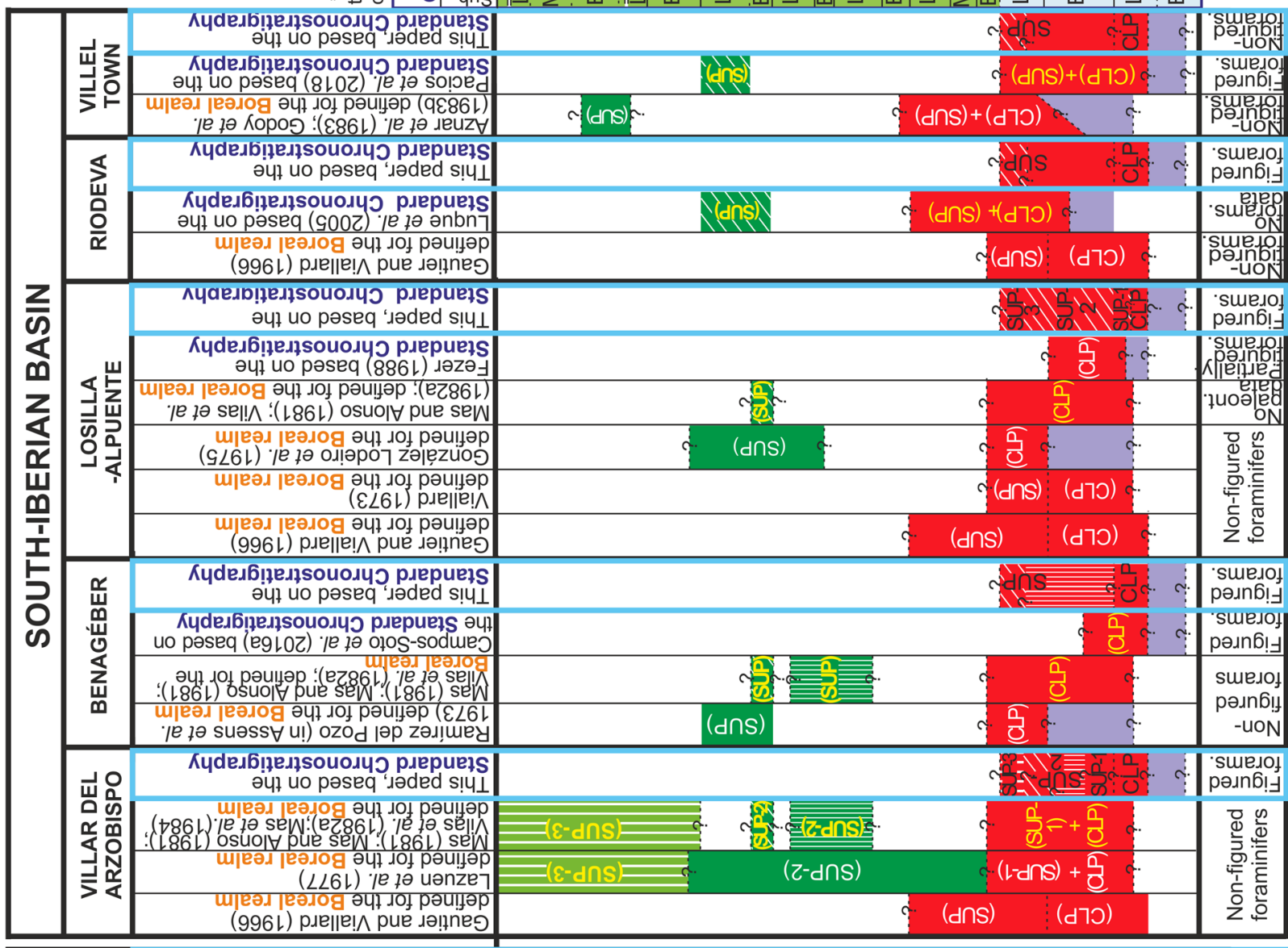

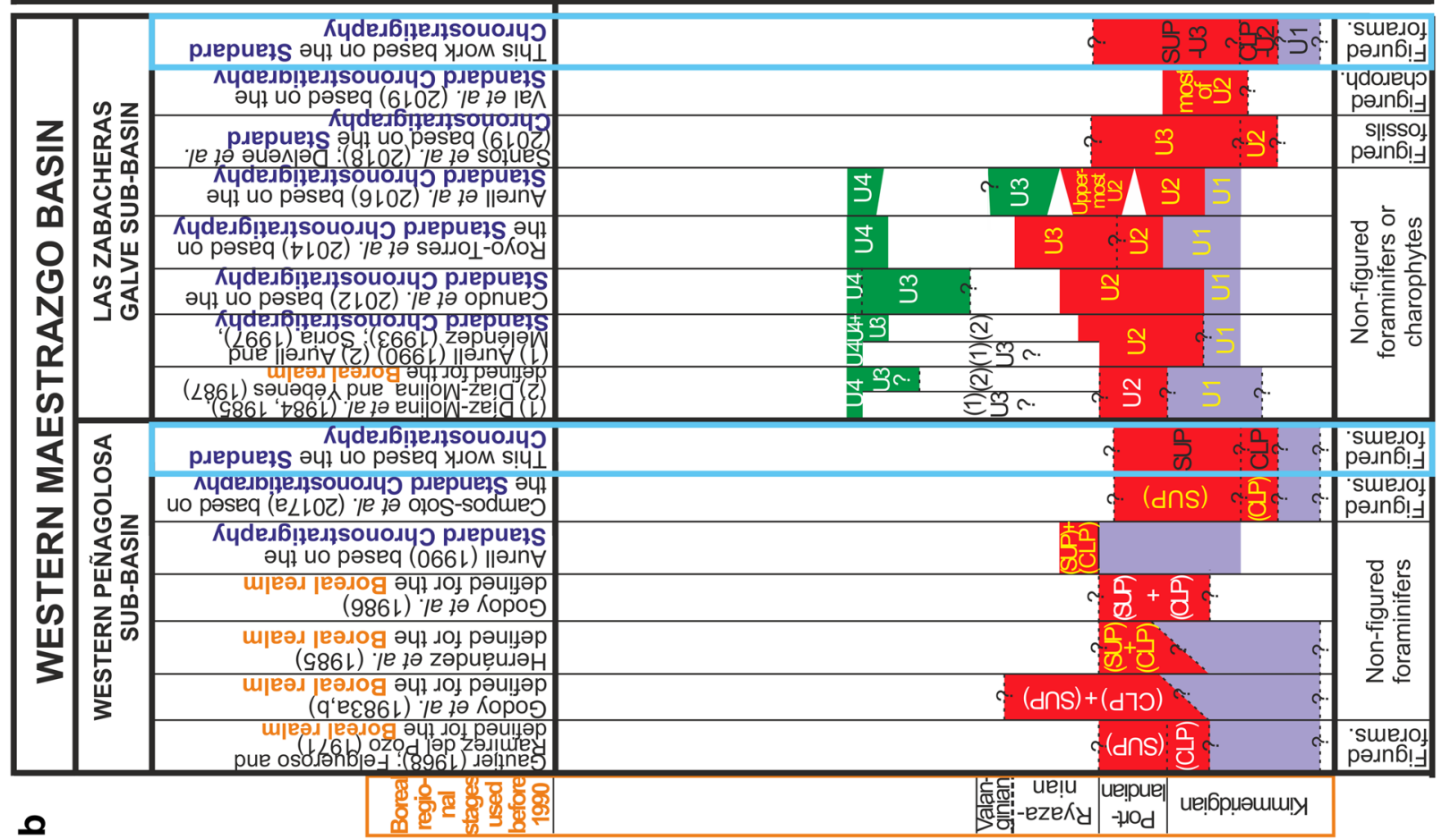


stratigraphy criteria (Salas et al. 2001). Locally in the western Peñagolosa sub-basin (Fig. 2), the Villar del Arzobispo Fm is overlain by the Mora de Rubielos Fm (Figs. 1d, 3a), a coastal-alluvial unit assigned to the Valanginian (Canérot et al. 1982), or to the Late Berriasian-Early Valanginian (Salas et al. 2001), based on its stratigraphic position. (2) In the South-Iberian Basin, deposits assigned to the Villar del Arzobispo Fm are locally overlain by those, essentially siliciclastic, of the Aldea de Cortés Fm, a unit which has been only described in the southwesternmost South-Iberian Basin (Figs. 1d, 2a, 3a). The Aldea de Cortés Fm has been attributed to the Valanginian-Hauterivian (Mas and Alonso 1981; Vilas et al. 1982a) or to the Tithonian (Campos-Soto et al. 2016a), although no palaeontological data supported this age (Fig. 1d; 3b, T1SM), and it has been interpreted as deposited in tidal, deltaic or coastal wetland settings (Mas et al. 2004; Campos-Soto et al. 2016a). (3) In the rest of the South-Iberian Basin, where the Aldea de Cortés Fm has not been described, deposits assigned to the Villar del Arzobispo Fm are overlain by those of the essentially siliciclastic El Collado Fm (Figs. 2, 3a), interpreted as deposited in fluvial and deltaic environments (Mas and Alonso 1981; Vilas et al. 1982a; Santisteban 1995; Mas et al. 2004), and attributed to the Late Hauterivian?-Early Barremian by Vilas et al. (1982a), and to the Barremian by Salas et al. (2001) and Mas et al. (2004), based on stratigraphic criteria (Fig. 3b, T1SM). Deposits of the El Collado Fm are, in turn, overlain by Aptian and Albian carbonate and/or siliciclastic deposits (equivalent to the "Urgonian" and the "Utrillas" facies, respectively), depending on the region (Fig. 1d; Mas 1981; Mas and Alonso 1981; Mas et al. 2004).

Nonetheless, it is important to note that in many of the studied areas, there is controversy about the nomenclature, limits and age of the formal lithostratigraphic units that contain the dinosaur fossils. In this regard, Figs. 2 and 3a, b show, in each area, both, the interpretations made by previous authors, and those made in this work based on new palaeontological and stratigraphic data. Thus, due to these controversies, we have preferred to use throughout the paper the term "studied dinosaur-bearing sedimentary record", or DSR, instead of using the names of the formal lithostratigraphic units defined and/or described by previous authors in each area, which, in turn, will be discussed in Sect. 5.2.

\section{Materials and methods}

In addition to the review of previous literature, detailed in T1SM, ten stratigraphic sections have been logged and numerous isolated outcrops have been studied, mapped and sampled (Figs. 2, 3a). Five stratigraphic sections have been logged in the western Maestrazgo Basin: four of them in the Peñagolosa sub-basin (Cedrillas, El Castellar, Formiche Alto and Mora de Rubielos), and one in the Galve sub-basin, the Las Zabacheras section, where the first dinosaur named in Spain, Aragosaurus ischiatus, was defined by Sanz et al. (1987) in the "Las Zabacheras" fossil site. In the South-Iberian Basin, five stratigraphic sections have been studied: the Villar del Arzobispo, the Benagéber and the Losilla-Alpuente areas, in the Valencia province, and the Riodeva and Villel town areas, in the Teruel province (Figs. 2, 3a). The studied areas were mapped based on field observations, satellite images, and geological information provided by the Spanish Geological Survey (GEODE, scale 1:50,000, López-Olmedo et al. 2018), which were integrated, together with the location of the studied sections and outcrops, using ArcGIS software (Fig. 2). More than 820 rock samples were collected along the stratigraphic sections and the other studied outcrops for stratigraphic, palaeoenvironmental, micropalaeontological and biostratigraphic studies. From each rock sample, a thin section was prepared and analyzed under transmitted-light microscopy. The micropalaeontological and biostratigraphic analysis is based on larger benthic foraminifera (LBF). LBF are classified at genus level, following the classification of Loeblich and Tappan (1988), and, when possible, at species level (see detailed methodology and discussion about the use of LBF as biostratigraphic markers in Campos-Soto et al. 2017a and Table 2A of supplementary material, T2ASM, for taxonomic list of the benthic foraminiferal taxa identified in this work). Classification of carbonate rocks of Dunham (1962) was used for petrographic and sedimentological descriptions. This work also includes some of the main dinosaur sites inventoried in the studied area by the Fundación Conjunto Paleontológico de Teruel-Dinópolis since 2002 in the Teruel province, and those published by other authors (particularly those from which fossils are defined as new taxa and/or are scientifically highly relevant) in the Teruel and Valencia provinces (see Table 2B of supplementary material, T2BSM, for taxonomic list of the dinosaur species and ichnospecies, and see Table 3 of supplementary material, T3SM, for the summary of the main dinosaur sites of the DSR in the studied areas and Fig. 3a for their probable stratigraphic position).

\section{Results: the studied dinosaur-bearing sedimentary record (DSR) of eastern Spain}

The sedimentary features (detailed in Table 1), as well as the occurrence of LBF and dinosaur fossils of the studied dinosaur-bearing sedimentary record (DSR) have been analyzed in detail in different areas of the western Maestrazgo and the South-Iberian basins, particularly in some areas where dinosaur remains are most abundant (Figs. 2, 3a, b; 


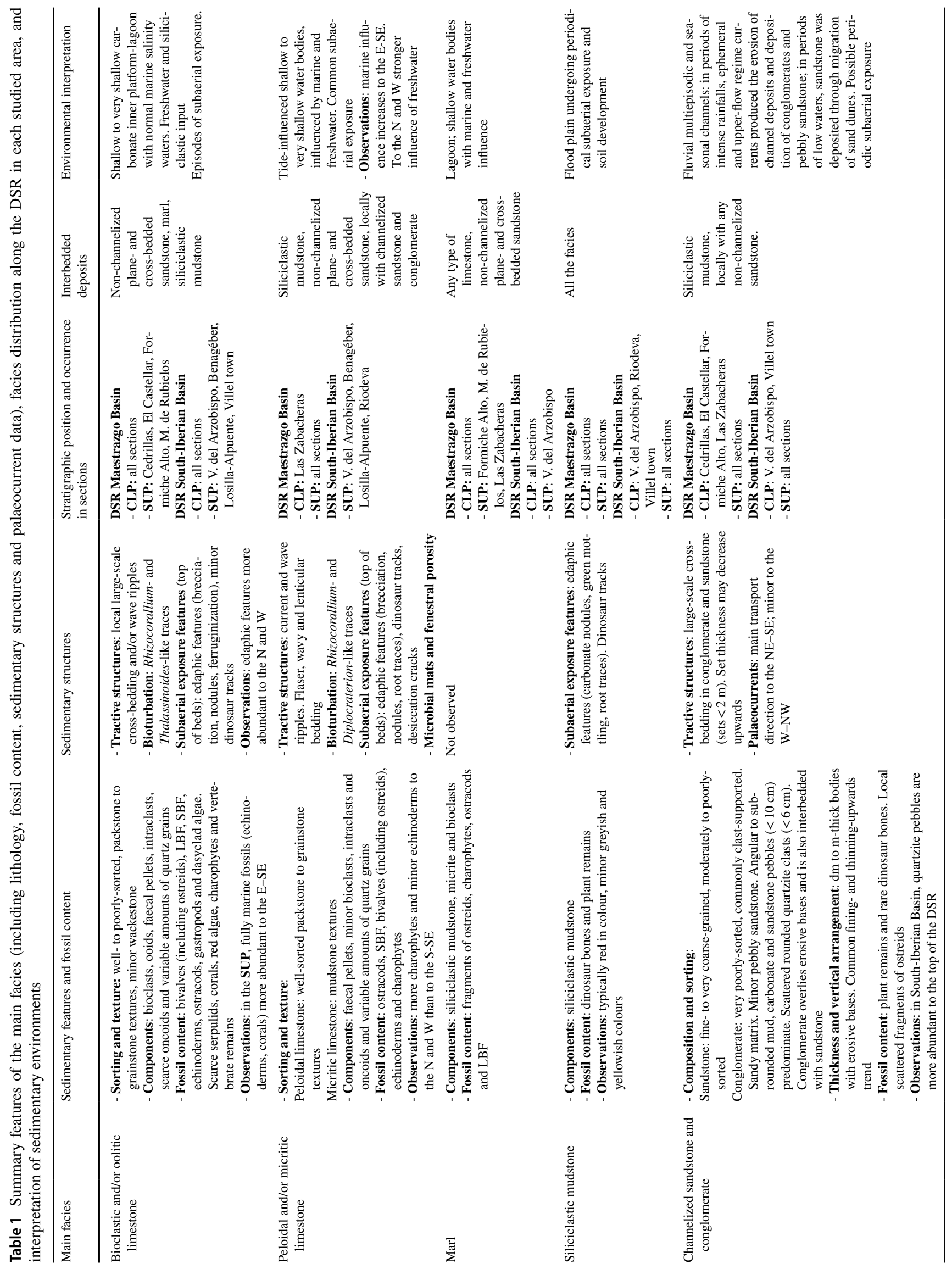




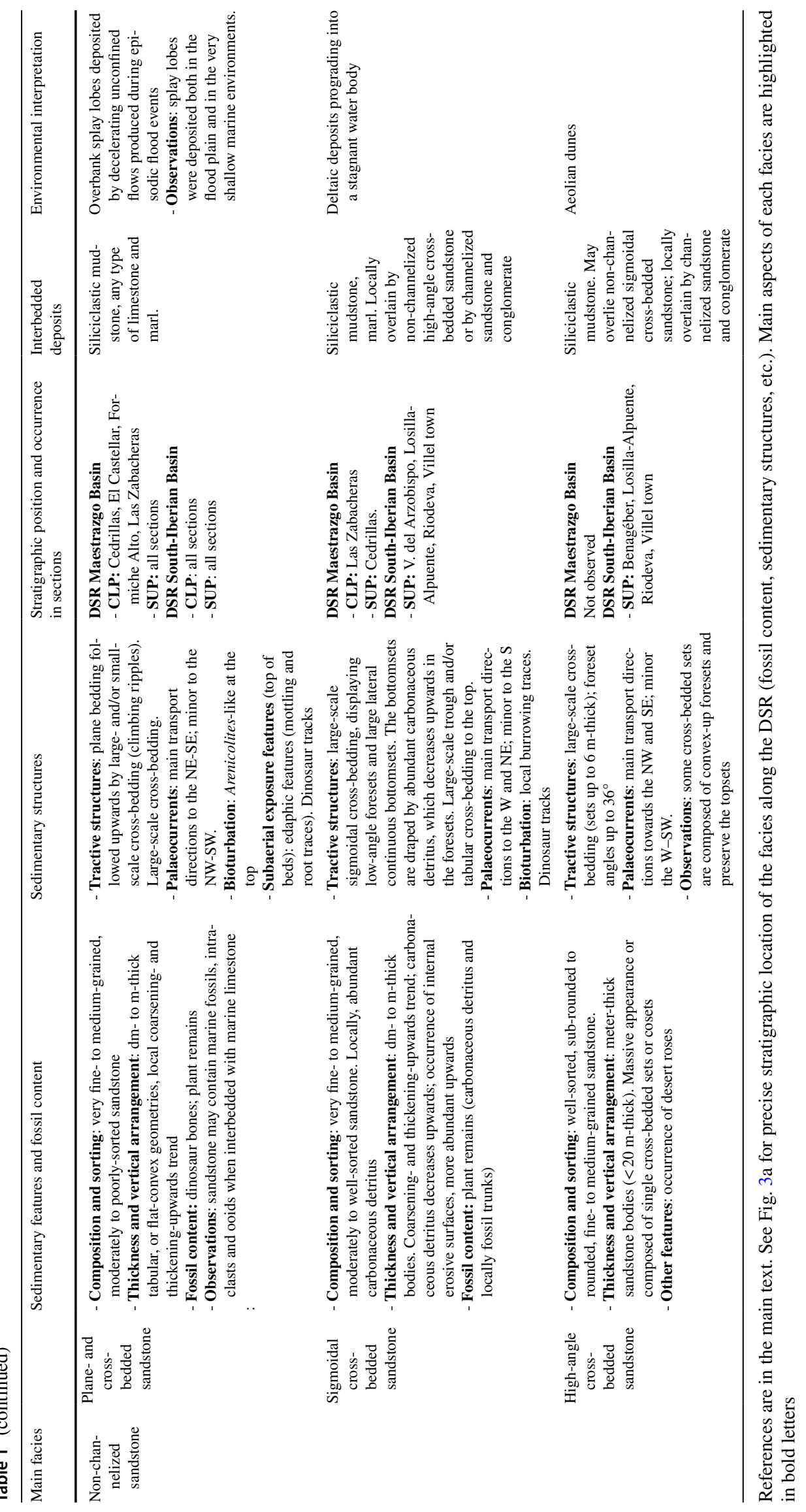


Table 1; T1SM-T3SM). Deposits of the western Maestrazgo Basin (Figs. 1, 2) will be described first because they may be considered as a stratigraphic and palaeontological reference, since the DSR is very well exposed and complete, specifically in the western Peñagolosa sub-basin, and contains abundant LBF, which have allowed proper dating the base to the top (Campos-Soto et al. 2017a).

\subsection{The western Maestrazgo Basin}

Deposits of the DSR in the western Maestrazgo Basin (Figs. 1, 3a) have been traditionally included in the Villar del Arzobispo Fm (e.g. Hernández et al. 1985; Aurell et al. 1994; Bádenas et al. 2004; Alcalá et al. 2009; Cobos et al. 2010; Royo-Torres et al. 2014; Campos-Soto et al. 2017a; Santos et al. 2018); in fact, the parastratoptype of this formation was defined in the Cedrillas area by Mas et al. (2004). Regarding the age, the DSR has been previously considered as Kimmeridgian-Portlandian (in the sense of the BRC), as Tithonian-Berriasian, in the sense of the SC and, recently, as Kimmeridgian-Tithonian (in the sense of the SC) in the western Peñagolosa sub-basin (see Fig. $3 b$ and T1SM for references and details).

The DSR at this basin has been subdivided in two informal parts (Figs. 3a, 4a, 5a): an essentially carbonate lower part (CLP) and an essentially siliciclastic upper part (SUP). The CLP (Fig. 3a) is mainly composed of bioclastic and/ or oolitic limestone, displaying packstone and grainstone textures, and containing abundant marine fossils, burrowing and subaerial exposure features at the top of some beds (Figs. 3a, 4b, e-g, 5b, c; see Table 1 for facies details); however, in the northern Las Zabacheras section, limestone of the upper part of the CLP are peloidal and/or micritic and contain charophytes and scarce marine fossils (Figs. 3a, 5d; Table 1). Limestone beds in all the sections are interbedded with marl, siliciclastic mudstone, non-channelized sandstone (plane- and cross-bedded, and locally sigmoidal cross-bedded) and minor channelized sandstone and conglomerate (Figs. 3a, 4a-d, 5a, b, e-g; Table 1 for details). Scattered dinosaur tracks have been observed at the top of some limestone beds (Fig. 3a; see details in Campos-Soto et al. 2017a).

The limit between the CLP and the SUP in the southern Formiche Alto section, is gradual (Fig. 3a) and is marked by a decrease in the number and thickness of limestone beds, as well as by a decrease in the marine influence. In the northern Las Zabacheras, Cedrillas and El Castellar sections, which are less thick than the southern sections, the limit between the CLP and the SUP is sharp and coincides with the last appearance of limestone beds, which may display subaerial exposure features, and/or bioturbation (Fig. 3a; Table 1).

In the SUP (Figs. 3a, 4a, h-n; 5a, f, h-j; Table 1), reddish siliciclastic mudstone is the most abundant facies, and is interbedded with non-channelized sandstone (plane- and
Fig. 4 Photographs of the studied dinosaur-bearing sedimentary record (DSR) in the western Peñagolosa sub-basin (western Maestrazgo Basin). a Field photograph showing the DSR in an area close to where the El Castellar section was logged (see Fig. 2 for location): the lower part (CLP), to the left, has a relative high topographic relief and comprises alternating limestone beds (greyish colour, blue arrows), siliciclastic mudstone (mostly covered) and minor sandstone; the upper part (SUP), to the right, is mainly composed of reddish siliciclastic mudstone (partially covered), alternating with sandstone and minor limestone. b-g Photographs of the CLP of the DSR. B) Field photograph of the Cedrillas area (where the parastratotype of the Villar del Arzobispo Fm was defined, see Fig. 2 for location) showing alternating limestone (blue arrow), greyish or reddish siliciclastic mudstone and sandstone (yellow arrow). c Field photograph of the Cedrillas section showing alternating reddish conglomerate (yellow arrow), siliciclastic mudstone and limestone (blue arrow). d Detail of the conglomerate shown in c. Conglomerate is clast-supported, poorly sorted, and composed of angular to sub-angular soft clasts. e Field photograph of a bioclastic and sandy limestone showing abundant bivalves (including some ostreids, arrows). Coin diameter: $23.25 \mathrm{~mm}$. f Photomicrograph of a bioclastic and oolitic limestone showing larger benthic forams (LBF), mollusk fragments and minor ooids (El Castellar section). g Photomicrograph of sandy bioclastic and oolitic limestone of the Cedrillas section containing gastropod and bivalve fragments, as well as small ooids (pink arrows), and scattered echinoderm fragments (yellow arrow). $\mathbf{h}-\mathbf{n}$ Photographs of the SUP of the DSR. h Alternating reddish siliciclastic mudstone and decimeter-thick non-channelized plane- and cross-bedded sandstone (yellow arrows). i Meter-thick and largely continuous channelized sandstone body displaying large-scale cross-bedding (yellow arrows), which overlies alternating greyish siliciclastic mudstone and decimeter-thick sandstone. $\mathbf{j}$ Peloidal and/or micritic limestone beds (Cedrillas section). Limestone is laminated and overlies reddish siliciclastic mudstone displaying root traces (green arrows). $\mathbf{k}$ Photomicrograph showing peloidal grainstone of the Cedrillas section containing abundant quartz grains and scattered smaller benthic foraminifera (SBF, white arrows). 1 Micritic limestone of the El Castellar section displaying fenestral pososity (black arrow) and burrowing (red arrow), comprising peloidal limestone in its interior. Note the similarity of $\mathbf{k}, \mathbf{l}$ with Fig. 5i and j, respectively. $\mathbf{m}$ Bioclastic and oolitic limestone of the El Castellar section mainly composed of mollusk fragments and scattered benthic foraminifera (blue arrow), charophytes (green arrow) and ooids. n Oolitic grainstone, containing abundant quartz grains, of the Mora de Rubielos section

cross-bedded, and locally sigmoidal cross-bedded), channelized sandstone and conglomerate, similar to those of the CLP, and minor limestone and marl. Abundant dinosaur tracks and bone remains occur in siliciclastic mudstone, sandstone and limestone (Fig. 5k, 1; 7, 9 and 10 of CamposSoto et al. 2017a). Limestone is more abundant towards the top of the SUP, and also progressively more abundant (Fig. 3a) and with greater lateral continuity to the southern areas. Two different types of limestone have been observed in the SUP (Fig. 3a, Table 1 for detailed description): (a) Peloidal and/or micritic limestone (Figs. 3a, 4j-1; 5i, j), which displays packstone/grainstone or mudstone textures respectively, contains scarce marine fossils (very scarce in the Las Zabacheras section), and displays abundant subaerial 

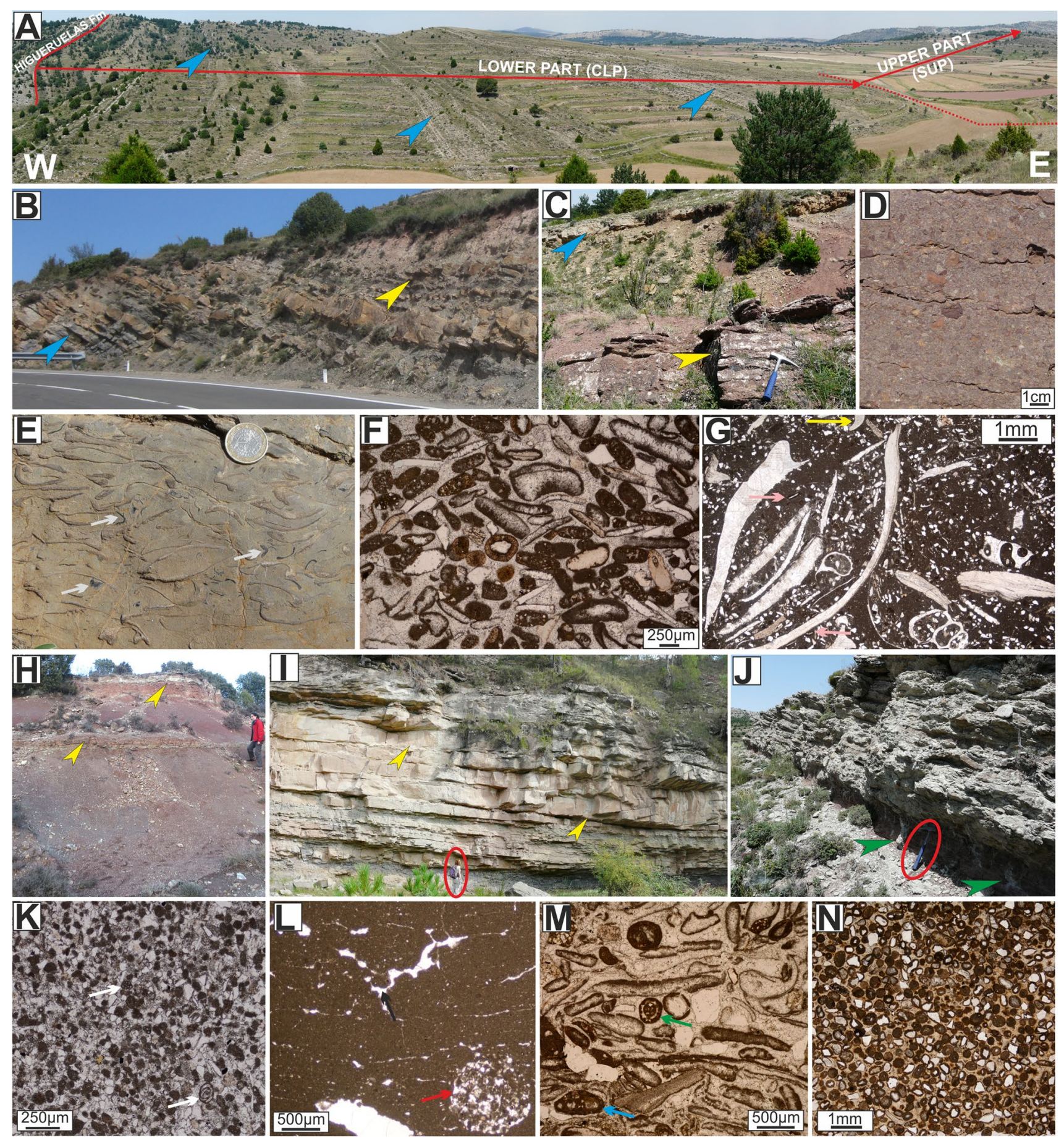

exposure features, including dinosaur tracks. Additionally, an oncolitic bed has been observed few meters below the "Las Zabacheras" fossil site (Fig. 5h), whose oncoids have large bivalves as nuclei (Delvene et al. 2019), similarly to those observed in the Riodeva and Villel town sections (see below, Figs. 111, 12d). (b) Bioclastic and/or oolitic limestone, similar to that of the CLP, which contain abundant marine fossils and burrowing and minor subaerial exposure features (Figs. 3a, 4m, n; Table 1). Bioclastic and/or oolitic limestone occurs throughout the SUP in the southern sections, where abundant marine bioclasts including colonial corals in life position, are observed; however, in the northern Cedrillas and El Castellar sections they only occur towards the top of the DSR (Fig. 3a), and in the Las Zabacheras section they are absent.

LBF have been observed in bioclastic and/or oolitic limestone of the CLP and the SUP of the DSR (Figs. 3a, 6a-f). In the CLP, the occurrence of Alveosepta jaccardi and 
Alveospeta personata has been determined in Las Zabacheras, Cedrillas and El Castellar sections (Figs. 3a, 6a-c). Moreover, Mesoendothyra? and Everticyclammina? have been identified in the Las Zabacheras section (Figs. 3a, 6d; T1SM for details), and Pseudocyclammina sp., Everticyclammina cf. virguliana and Kurnubia gr. palastiniensis have been determined in the CLP of the Cedrillas and El Castellar sections (Fig. 3a; see T1SM and Campos-Soto et al. 2017a for details). In limestone beds of uppermost part of the SUP in the Cedrillas, Formiche Alto and Mora de Rubielos sections, there is a LBF assemblage dominated by Anchispirocyclina lusitanica, mainly associated with Choffatella cf. tingitana, and with rare Rectocyclammina, Everticyclammina, Nautiloculina and Andersenolina (Figs. 3a, 6e, f; see T1SM and Campos-Soto et al. 2017a for details). In the Las Zabacheras section, where bioclastic and/or oolitic limestone beds are not recorded in the SUP of the DSR, we have not observed foraminifera with chronostratigraphic value in the SUP.

Regarding dinosaurs, the DSR at the western Maestrazgo basin includes abundant dinosaur fossils. The DSR at the western Peñagolosa sub-basin includes sauropod, theropod, ornithopod and thyreophoran dinosaur tracks and bones (e.g. Cobos et al. 2005, 2010, 2012b, 2014, 2015; Alcalá et al. 2014a, b; Campos-Soto et al. 2017a; see T3SM for details). The study of the tracks has allowed to define the ichnotaxa Deltapodus ibericus and Iberosauripus grandis (Cobos et al. 2010, 2014, respectively). Dinosaur bones include several postcranial elements of the stegosaurid Dacentrurus (Cobos et al. 2010), sauropod fossils (some of them assigned to Diplodocoidea indet, Cobos et al. 2015, 2017) and a large theropod tooth assigned to Megalosauridae indet (Cobos et al. 2014, 2015). The DSR in the northern area (the Galve subbasin) is rich in dinosaur fossils (bones and tracks, Fig. 5k, 1; see Fig. 3a for the probable stratigraphic position of the dinosaur sites and T3SM for details and references). The study of sauropod bones has led to the description of two dinosaurs: the basal macronarian Aragosaurus ischiaticus (Sanz et al. 1987; Royo-Torres et al. 2014) from deposits of the SUP, and the titanosauriform Galveosaurus herreroi (Sánchez-Hernández 2005; Barco 2009) from the CLP. Other important sauropod fossils, with Jurassic affinities, are those atributed to Diplodocidae indet? from the CLP (Cuenca-Bescós et al. 1997; Sanchez-Hernández et al. 2007). Similar diversity has been interpreted from sauropod tracks (i.e. Castanera et al. 2011; Alcalá et al. 2012). Bones assigned to stegosaurs are largely fragmented (Pereda-Suberbiola et al. 2005; Cobos et al. 2012a), although tracks (Deltapodus) of these dinosaurs are relatively abundant (Mampel et al. 2010-2011; Herrero-Gascón and Pérez-Lorente 2017). Ornithopods are represented mainly by tracks, indicating both bipedal and quadrupedal locomotion (Mampel et al.
Fig. 5 Photographs of the DSR in the Las Zabacheras area (Galve sub-basin, western Maestrazgo Basin; see Fig. 2 for location). a Field photograph showing the DSR in an area close to where the Las Zabacheras section was logged (see Fig. 2 for location): the CLP of the DSR, with relative high topographic relief, to the left, is composed of limestone beds (greyish colour), alternating with reddish siliciclastic mudstone and sandstone; the SUP of the DSR is mainly composed of reddish siliciclastic mudstone, alternating with sandstone and scattered limestone. White asterisk marks the "Las Zabacheras" fossil site (see Fig. 3a for stratigraphic position). Yellow asterisk marks the location of $\mathbf{f}$. $\mathbf{b}-\mathbf{g}$ Photographs of the CLP of the DSR. b Field photograph showing limestone (blue arrow) alternating with greyish or reddish siliciclastic mudstone (partially covered) and channelized sandstone (yellow arrow). c Bioclastic and peloidal limestone containing LBF (blue arrows), SBF (miliolids, white arrows) and micritic intraclasts. d Sandy bioclastic and peloidal limestone containing mollusk fragments, scattered benthic foraminifera (blue arrow), charophytes (green arrow) and quartz grains. e One of the minor unconformities observed within deposits of the CLP (see f for location). Note the progressive upwards decrease of the dip angle. Blue arrows: limestone beds; yellow arrow: channelized sandstone bed. f Field photograph showing the limit between the CLP and the SUP of the DSR. The CLP is composed of alternating bioclastic and/or oolitic limestone (blue arrows), reddish siliciclastic mudstone (mostly covered), and non-channelized sandstone (plane- and cross-bedded and sigmoidal cross-bedded; yellow arrow). The SUP is mainly composed of reddish silicilastic mudstone. White asterisk marks the position of "Las Zabacheras" fossil site. Yellow asterisks mark the location of $\mathbf{e}, \mathbf{g}$. $\mathbf{g}$ Detail of a non-channelized sigmoidal cross-bedded sandstone body displaying large and low-angle crossbedding. $\mathbf{h}-\mathbf{j}$ Photographs of the SUP of the DSR. $\mathbf{h}$ Bed containing large oncoids below the "Las Zabacheras" fossil site (see Fig. 3a for stratigraphic location). The nuclei of the oncoids are bivalves. Coin diameter: $23.25 \mathrm{~mm}$. i Photomicrograph showing peloidal sandy limestone containing scattered SBF (white arrow). j Micritic limestone displaying fenestral porosity (black arrows) and burrowing (red arrow) filled with peloidal limestone. Note the similarity of $\mathbf{i}$ and $\mathbf{j}$ with Fig. 4k, 1, respectively. k Aragosaurus bone in the Las Zabacheras-site (SUP) in 2014. I Deltapodus track in the Barranco del Agua site (CLP) (Herrero-Gascón and Pérez-Lorente 2017)

2010-2011, Castanera et al. 2013). Some isolated theropod teeth have been attributed to Coelurosauria indet., Dromeosauridae indet. and Megalosauridae indet. (Ruiz-Omeñaca et al. 2004; Cobos et al. 2014) and some theropod tracks have been described (i.e. Pérez-Lorente and Herrero-Gascón 2007; Alcalá et al. 2012).

\subsection{The South-Iberian Basin}

In this basin, sedimentary features of the DSR are similar in the different studied areas (Fig. 3a; Table 1); however, most of the areas will be described separately because, in 3 of them, the lithostratigraphic units used by previous authors and in this work were formaly defined (see below), and because, in each area, the DSR includes deposits assigned previously to different ages and to different lithostratigraphic unis. 

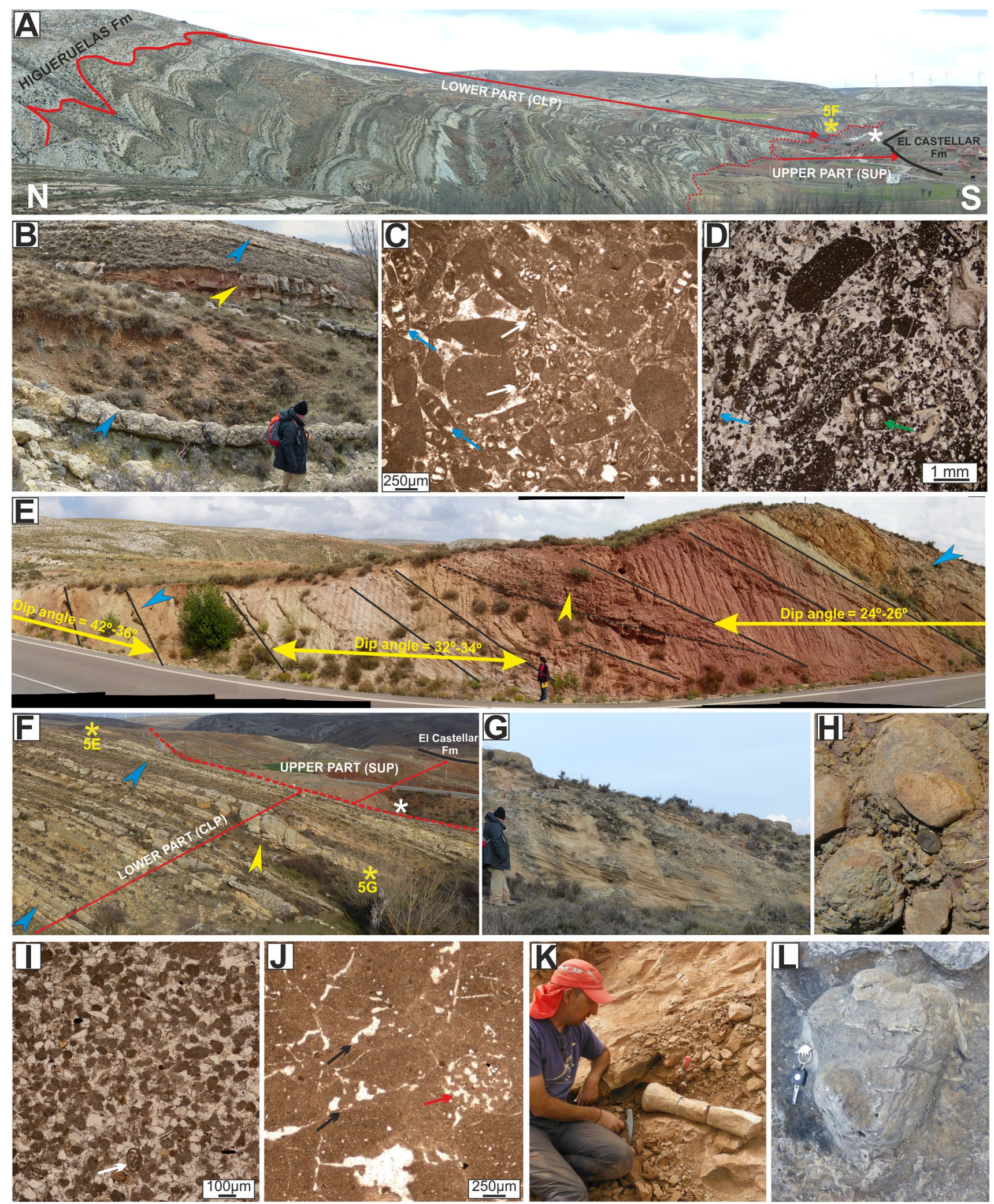


\subsubsection{The Villar del Arzobispo area}

In this area (Figs. 2, 3a, b, 7), the DSR has been divided in a carbonate-dominated lower part (CLP), and a siliciclastic-dominated upper part (SUP), which, in turn, has been subdivided in three segments (SUP-1, SUP-2 and SUP-3). Deposits of the CLP and the SUP-1 (Fig. 3a) correspond to those previously assigned to the Villar del Arzobispo Fm (Fig. 3a), which was formally defined in this area by Mas et al. (1984), and assigned to the Kimmeridgian-Portlandian or to the Tithonian-Berriasian, in the sense of the BRC and SC, respectively (see Fig. 3b and T1SM for references and details). The SUP-2 is essentially siliciclastic (Fig. 3a) and corresponds to deposits previously considered as belonging to the Aldea de Cortés and El Collado Fms (Mas and Alonso 1981; Vilas et al. 1982a; Mas et al. 2004), assigned by these authors to the Valanginian-Hauterivian and to the Late Hauterivian?-Early Barremian, respectively, but without support of palaeontological data (Fig. $3 \mathrm{~b}$ and T1SM for references and details). Deposits of the SUP-3 have been assigned, in the same area where the stratigraphic section has been logged, to the Aptian-Albian, but without giving any palaeontological data to support the age determination (Fig. 3a, b; T1SM for references and details).

The CLP and the SUP-1 are composed of bioclastic and/ or oolitic limestone (progressively less abundant upwards), which contain abundant marine fossils, even colonial corals in life position, and abundant burrowing (Figs. 3a, 7a-f; Table 1). Limestone is interbedded with marl, siliciclastic mudstone, channelized sandstone and conglomerate (Fig. 7g) and non-channelized sandstone (plane- and crossbedded, and sigmoidal cross-bedded), which may show occasional dinosaur tracks at the base (Fig. 7h).

Deposits of the SUP-2 (Fig. 3a) are partially covered or mined in this area and are composed of reddish siliciclastic mudstone alternating with channelized sandstone and conglomerate (Fig. 7i), non-channelized sandstone (plane- and cross-bedded, and sigmoidal cross-bedded), which may have dinosaur tracks at the base (Fig. $7 \mathrm{j}$ ), and very scarce thin peloidal and/or micritic limestone. Deposits of the SUP-3 are very similar to those of the SUP-2, but they are interbedded with bioclastic and/or oolitic limestone, which contain abundant marine fossils, and are very similar to those of the CLP and the SUP-1 (Figs. 3a, 7k-m; Table 1).

In this section, the study of LBF observed in the bioclastic and/or oolitic limestone beds of the CLP and SUP-1 has determined the occurrence of Alveosepta jaccardi-personata, together with Everticyclammina and Mesoendothyra? in limestone beds of the CLP, and the occurrence of Everticyclammina cf. virguliana, Rectocyclammina?, Nautiloculina and Mesoendothyra? in limestone beds of the SUP-1 (Figs. 3a, 8a-c). Moreover, and for the first time, the occurrence of Anchispirocyclina lusitanica, Everticyclammina and Rectocyclammina (Figs. 3a, 8d-f) has been determined in the bioclastic and/or oolitic limestone beds of SUP-3.

Regarding dinosaurs, this area is not particularly known for the record of dinosaur sites, and only occassional tracks are observed (see Fig. 7h).

\subsubsection{The Benagéber area}

The DSR in this area also includes (Figs. 3a, 9) an essentially carbonate lower part (CLP) and an essentially siliciclastic upper part (SUP). Deposits of the CLP are equivalent to those assigned by Mas and Alonso (1981) to the Villar del Arzobispo Fm (Fig. 3a, b; T1SM for details), which have been traditionally considered as Tithonian-Berriasian, but recently have been dated as Kimmeridgian by CamposSoto et al. (2016a). The SUP includes deposits traditionally assigned to the Aldea de Cortés Fm, formally defined in this area by Vilas et al. (1982a), and at least part of those of the El Collado Fm, which have been attributed to the Valangian-Hauterivian and to the Late Hauterivian?-Early Barremian, respectively, although the units lack palaeontological content for dating them accurately (Fig. 3a, b and T1SM for references and details). Recently, Campos-Soto et al. (2016a) have interpreted that the beginning of the deposition of the Aldea de Cortés Fm should be attributed to an age not younger than Tithonian, because the contact between the Villar del Arzobispo and the Aldea de Cortés Fms was revealed to be transitional and not unconformable as interpreted previously (Mas1981; Vilas et al. 1982a; Mas et al. 2004).

The CLP is mainly composed of bioclastic and/or oolitic limestone, containing abundant marine fossils, burrowing and minor subaerial exposure features. Limestone is interbedded with marl and non-channelized plane- and crossbedded sandstone (Figs. 3a, 9a-d; see Table 1 and CamposSoto et al. 2016a for details). Deposits of the SUP consist of alternating siliciclastic mudstone, channelized sandstone and conglomerate, non-channelized sandstone (plane- and crossbedded, and high-angle cross-bedded), and minor limestone, which displays burrowing and subaerial exposure features (Figs. 3a, e-n; Table 1). Limestone may be bioclastic and contain marine fossils (Fig. 91), or it may be peloidal and contain charophytes and scarce marine fossils (Fig. 9m-n). Scattered fragments of dinosaur bones have been observed within the siliciclastic deposits, when logging the stratigraphic section (Fig. 9h).

In this work, the occurrence of Alveosepta jaccardi and Redmondellina powersi has been determined and found in the bioclastic and/or oolitic limestone beds of the CLP (Figs. 3a, 8g), in addition to the LBF assemblage (dominated by Alveosepta personata associated with Kurnubia, "Labyrinthina" mirabilis and Nautiloculina oolithica; T1SM for details) determined by Campos-Soto et al. (2016a). 

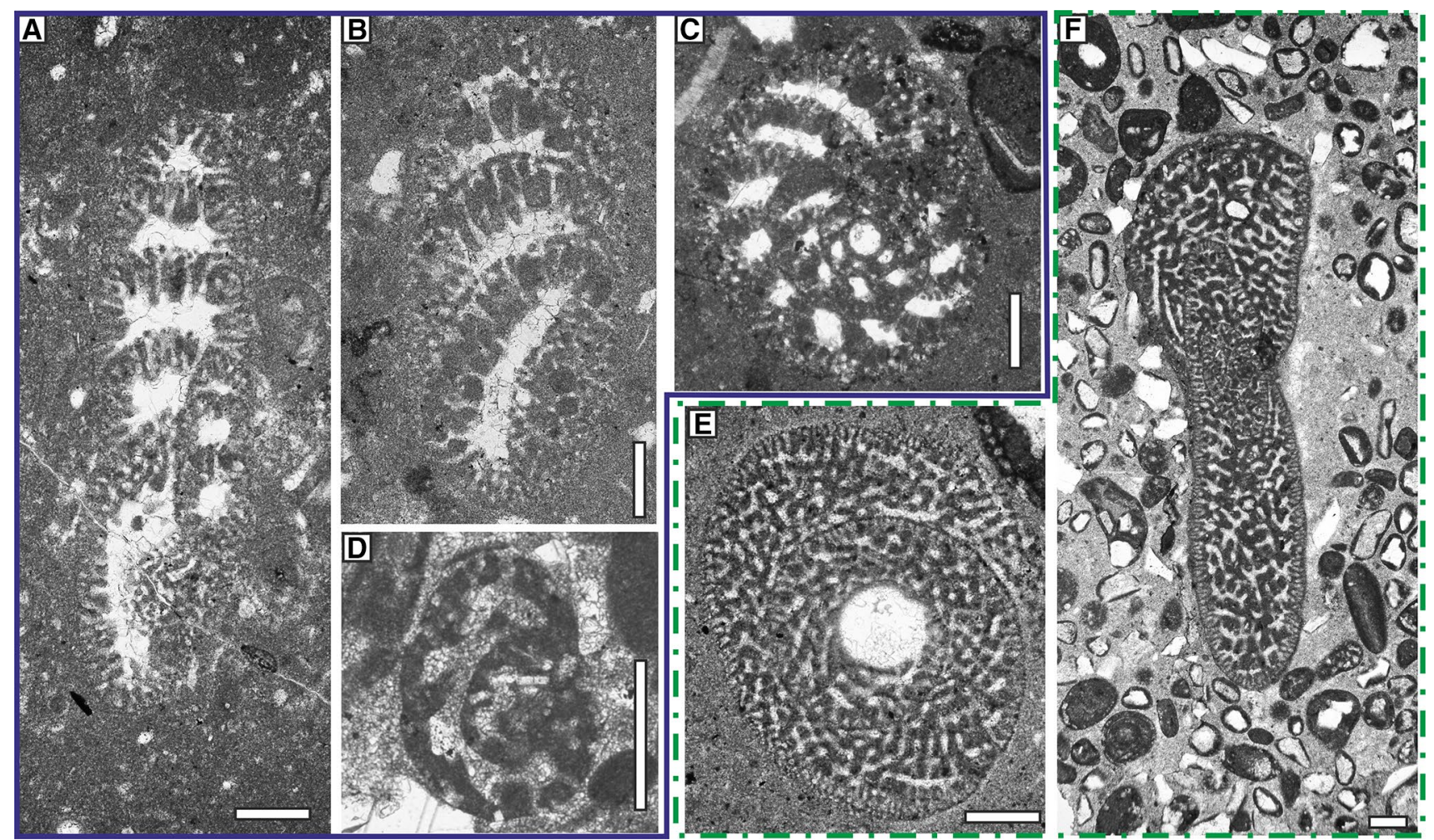

Fig. 6 Larger benthic foraminifera (LBF) observed in the western Maestrazgo Basin (see Figs. 2 and 3a for location of samples). a-d LBF observed in the CLP of DSR (dark blue line). $\mathbf{a}, \mathbf{b}$ Oblique sections of Alveosepta personata-jaccardi (samples ZB-C-10 and ZB-C23, respectively, of Las Zabacheras section). c Alveosepta personata. Equatorial section of a macrospheric specimen (sample CE-037 of Cedrillas section). d Everticyclammina (sample ZB-C-32 of Las
Zabacheras section). e, f LBF observed in the SUP of the DSR (green dotted line). e Equatorial section of Anchispirocyclina lusitanica (A-form; sample MO-3 of Mora de Rubielos section). f Anchispirocyclina lusitanica. Subaxial section near to the axial of a juvenile B-form (sample MO-19 of Mora de Rubielos section). Scale bar in all sections: $0.2 \mathrm{~mm}$
Moreover, in limestone beds of the SUP, small agglutinated benthic foraminifera similar to Mesoendothyra? have been observed.

Regarding dinosaur fossils, several sites have been historically mentioned at the Benagéber area (Pérez-García et al. 2009 and references therein; see Fig. 3a for the probable stratigraphic location of the dinosaur sites and T3SM for details and more references), in the deposits assigned to the Aldea de Cortés Fm by Campos-Soto et al. (2016a). Royo y Gómez (1927) assigned dinosaur remains from the Benagéber area to the "Purbeck facies" and noted that the remains attributed to sauropods would probably correspond to a new dinosaur genus, which would represent the largest dinosaur in Europe. Among the sauropod fossils, Royo y Gómez (1926) listed a tooth fragment, which he described as very similar to a sauropod tooth of the Upper Jurassic of Wimille in France, classified as "Neosodon" (Moussaye de la 1885; Pérez-García et al. 2009). About 80 years later, RoyoTorres et al. (2006) have assigned "Neosodon" teeth to the Turiasauria clade (Royo-Torres et al. 2006; 2009) together with the Jurassic sauropods Turiasaurus riodevensis and
Losillasaurus giganteus, which were discovered relatively close to the Benagéber area, in the Riodeva and LosillaAlpuente areas, respectively (Fig. 2), in the deposits of the Villar del Arzobispo Fm (see Sects. 4.2.3 and 4.2.4, and T3SM).

\subsubsection{The Losilla-Alpuente area}

In this area (Figs. 2, 3), the DSR also includes a lower part (CLP), essentially carbonate, and an upper part (SUP), essentially siliciclastic (Fig. 3a). The CLP is equivalent to deposits previously assigned to the "Purbeckian" Villar del Arzobispo Fm (e.g. Mas and Alonso 1981; Santisteban 1995; Fig. 3a), which has been commonly assigned to ages ranging from the Kimmeridgian to the Portlandian (in the sense of the BRC) or to the Late Kimmeridgian-Early Tithonian in the sense of the SC (Fig. 3b and T1SM for references and details). The SUP, which has been subdivided in three segments (SUP-1 to SUP-3) based on the presence or absence of limestone beds, is equivalent to deposits previously assigned to the "Wealden" El Collado Fm (Fig. 3a), formally defined 
in this area by Vilas et al. (1982a), and has been assigned to ages ranging from the Portlandian to the Early Valanginian or from the Hauterivian to the Early Aptian, although fossils with cronostratigraphic value are not reported (Fig. $3 \mathrm{~b}$ and T1SM for references details).

Nevertheless, it should be noted that the upper limit of deposits previously assigned to the Villar del Arzobispo Fm with those of the El Collado Fm is controversial in this area. Mas and Alonso (1981) established the upper limit of the Villar del Arzobispo Fm in the last limestone bed cropping out in the stratigraphic section that they measured in the same area logged for this work (Fig. 3a). Santisteban (1995) logged a stratigraphic section in the Alpuente area and divided the essentially siliciclastic deposits of the "Wealden" El Collado Fm in 5 informal units (Fig. 3a), the two lower ones (A-B) containing marine limestone beds interbedded with siliciclastics, in contrast to the upper ones (C-E). Casanovas-Cladellas et al. (1999) described the presence of stegosaurs in the carbonate-bearing units, A and B of Santisteban (1995), and assigned them to the uppermost Jurassic (see T3SM). Later, both units were incorporated into the Villar del Arzobispo Fm by Santisteban and Suñer (2002). Afterwards, Luque et al. (2005), Santisteban and Esperante (2005), Royo-Torres et al. (2006) and Santisteban and Santos-Cubedo (2010) have interpreted that at least part of the siliciclastic deposits of the overlying units (unit C of Santisteban 1995) should be included in the Villar del Arzobispo Fm and not in the El Collado Fm, in accordance with its dinosaur fauna with Jurassic affinity (see Fig. 3a and T3SM). However, none of the above mentioned authors provide detailed stratigraphic sections or maps that allow to precise the limit between both units.

As in the other areas of the South-Iberian and Maestrazgo basins, the CLP is composed of bioclastic and/or oolitic limestone, with abundant marine biota, burrowing and minor subaerial exposure features, which alternate with marl, and non-channelized plane- and cross-bedded sandstone (Figs. 3a, 10a-c; Table 1).

The SUP (Figs. 3a, 10d-1; Table 1) is mainly composed of siliciclastic mudstone, alternating with channelized sandstone and conglomerate, and non-channelized sandstone (plane- and cross-bedded, sigmoidal cross-bedded, and high-angle cross-bedded), which may show dinosaur tracks (Fig. 10e) and may contain bone fragments (scatteredly observed while the stratigraphic section was logged). Moreover, interbedded with siliciclastics of the SUP-1 and SUP-3, there are bioclastic and/or oolitic limestone containing abundant marine biota, and minor peloidal and/or micritic limestone, containing scarce marine fossils (Figs. 3a, 10f-1; Table 1), similarly to what occurs in other studied areas, both of the South-Iberian and in the western Maestrazgo basins (Fig. 3a).
Fig. 7 Photographs of the DSR in the Villar del Arzobispo area (see Fig. 2 for location). a-h Photographs of the CLP of the DSR (see Fig. 3a for stratigraphic location). a Bioclastic and/or oolitic limestone beds alternating with marl. b Rhizocorallium-type burrowing. c Colony of branching corals found in life position. d Bioclastic limestone containing abundant LBF, other rounded bioclast fragments, and minor ooids. e Bioclastic and oolitic limestone containing mollusk fragments, gastropods, equinoderms (yellow arrows), intraclasts and quartz grains. f Sandy bioclastic and peloidal limestone containing bivalve fragments and ostracods (orange arrows). g Meter-thick chanellized sandstone body overlain by an alternation of siliciclastic mudstone and decimeter- to centimeter-thick non-channelized planeand cross-bedded sandstone. Dinosaur natural casts are observed at the base of decimeter- to centimeter-thick sandstone bed (red square). h Detail of the dinosaur track (red arrow) marked in $\mathbf{g}$. $\mathbf{i}-\mathbf{m}$ Photographs of the SUP of the DSR (see Fig. 3a for stratigraphic location). i Reddish siliciclastic mudstone alternating with a meter-thick channelized white sandstone body of the SUP-2. j Decimeter-thick nonchannelized plane- and cross-bedded sandstone displaying dinosaur tracks at the base (red arrows), and alternating with reddish siliciclastic mudstone in SUP-2. k The SUP-3 is composed of bioclastic and/ or oolitic limestone beds (blue arrow, to the left of the photograph), alternating with marl, which is overlain by an alternation of reddish or greenish siliciclastic mudstone and white sandstone (yellow arrow), to the right of the photograph. 1 Oolitic limestone, containing mollusk fragments, and LBF (blue arrow) of the SUP-3. m Peloidal and bioclastic limestone of the SUP-3 containing bivalve fragments, LBF (blue arrow), and small ooids

Bioclastic and/or oolitic limestone beds of the CLP contain a LBF assemblage dominated by Alveosepta personata, Alveosepta jaccardi and Redmondellina powersi, associated to Kurnubia gr. palastiniensis, Pseudocyclammina? Rectocyclammina?, Mesoendothyra? Everticyclammina, Andersenolina, Parurgonina and Feurtillia (Figs. 3a, 8h-1). Moreover, and for the first time, Alveosepta jaccardi-personata, Redmondellina powersi, together with Siphovalvulina, Mesoendothyra? Nautiloculina, Everticyclammina? and Pseudocyclammina have been identified in the bioclastic and/or oolitic limestone beds of the SUP-1 (Figs. 3a, 8m, n). In addition, and also for the first time, the occurrence of Anchispirocyclina lusitanica, Everticyclammina and Rectocyclammina has been identified in the bioclastic and/or oolitic limestone beds of the SUP-3 (Figs. 3a, 8o, p).

Regarding dinosaur fossils, in this area, the DSR contains abundant dinosaur remains (see Fig. 3a for the probable stratigraphic position of the dinosaur sites within the DSR, and T3SM for details and additional references). In deposits of the SUP, there are abundant tracks and bones of theropods, ornithopods and sauropods (i.e. Santisteban et al. 2003, 2009). Among the dinosaur bones, it is relevant the high diversity of sauropods, mainly represented by turiasaurs as Losillasaurus giganteus, defined by CasanovasCladellas et al. (2001) in Aras de Alpuente (currently Aras de los Olmos, Royo-Torres et al. 2006), diplodocoids and titanosaurforms (Suñer et al. 2014). There are also abundant stegosaurid fossil sites, which have been assigned to Dacentrurus armatus (Casanovas-Cladellas et al. 1999), 

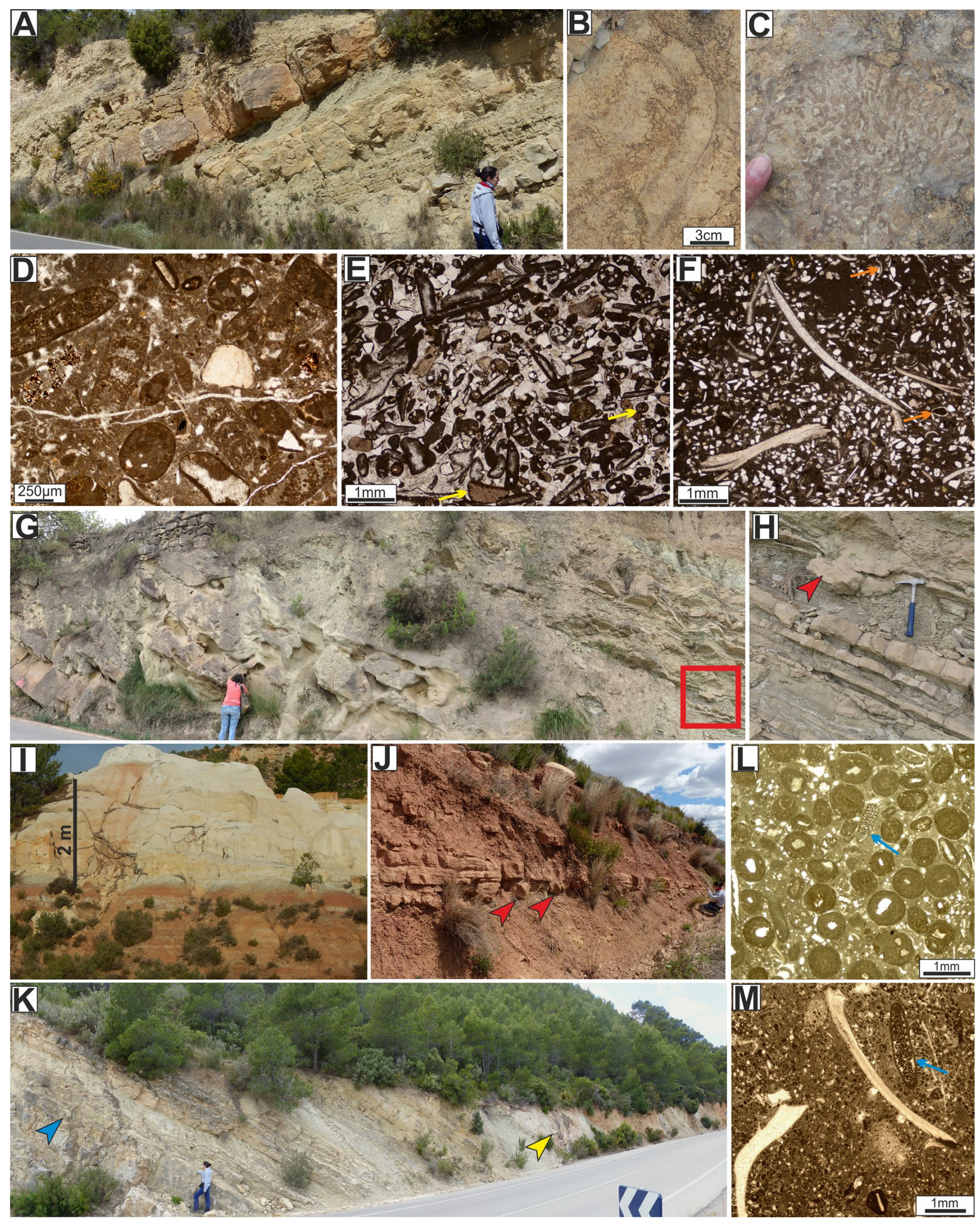
Dacentrurus sp. (Maidment et al. 2008) and Dacentrurinae indet. (Company et al. 2010). Ornithopods are less abundant (Pereda-Suberbiola et al. 2009) and the theropods are essentially known by some isolated teeth, some of them assigned to Coelurosauria indet. and Megalosauridae? indet. (Suñer et al. 2005; Cobos et al. 2014).

\subsubsection{The western areas of the South-Iberian Basin: the Riodeva and the Villel town areas}

In these areas, the DSR may be also subdivided in a carbonate-dominated lower part (CLP) and a siliciclasticdominated upper part (SUP; Figs. 3a, 11a, b, 12a). Deposits of the CLP (Fig. 3a) have been assigned to the Villar del Arzobispo Fm in both areas (Luque et al. 2005; Bádenas et al. 2008-2009; Pacios et al. 2018), and have been assigned from the Kimmeridgian to the Portlandian, in the sense of the BRC, and to the Tithonian or, more recently in the Villel town area, to the Kimmeridgian, in the sense of the SC (Fig. 3b and T1SM for references details). Deposits of the SUP have been previously assigned to the Villar del Arzobispo and El Collado Fms (sensu Luque et al. 2005 and Pacios et al. 2018, at Riodeva and Villel town sections, respectively). In both areas, the deposits of the SUP assigned to the Villar del Arzobispo Fm have been attributed to the Late Kimmeridgian-Portlandian-Early Valanginian (in the sense of the BRC), or to the Tithonian-Berriasian; the deposits interpreted as equivalent to the El Collado Fm have been assigned from the Barremian to the Albian?, but without having any fossil with chronostratigraphic significance (see Fig. 3b and T1SM for references and details).

Deposits of the CLP are similar to those observed in the CLP of the DSR studied in the other areas and is mainly composed of bioclastic and/or oolitic limestone containing abundant marine fossils and burrowing and minor edaphic features (Figs. 3a, 11c, d, 12b-d; Table 1). Limestone alternates with marl, siliciclastic mudstone, non-channelized plane- and cross-bedded sandstone, and locally with channelized sandstone and conglomerate. However, it should be noted that, towards the northwesternmost Villel town area, there is a decrease in the abundance of limestone beds and fully marine biota (Fig. 3a). Dinosaur tracks (RoyoTorres et al. 2009), and some fragmentary bones have been observed at the top of limestone beds (Fig. 3a).

The SUP (Figs. 3a, 11a, e-1; 12a, e; Table 1) is composed of reddish siliciclastic mudstone alternating with channelized sandstone and conglomerate, and non-channelized sandstone (plane- and cross-bedded, sigmoidal cross-bedded, and high-angle cross-bedded), which may display dinosaur tracks at their bases and may contain large dinosaur bone remains (Fig. 11e-h). Limestone beds (bioclastic, oolitic, peloidal and/or micritic) containing marine fossils (Figs. 3a, 11i-1, 12g), and stromatolitic and oncolitic beds
Fig. 8 Larger benthic foraminifera (LBF) of the DSR in the SouthIberian Basin (see Figs. 2 and $3 a$ for location of samples). a-f LBF observed along the DSR in the Villar del Arzobispo area (dotted red line): a, c Lower part (CLP); b Upper part (SUP-1); d-f SUP-3. a Oblique section of Alveosepta personata-jaccardi (sample VILLINF-1B). b Everticyclammina (sample VILL-SUP-11B). Note the exoskeletal elements in the last chamber. The coarse agglutinated grains mask the exoskeletal elements in the inner chambers. It lacks endoskeleton. c Subaxial section of a probable small Everticyclammina (sample VILL-INF-1B). d Anchispirocyclina lusitanica. Axial section of an A-form (sample VILL-VILL-1). e A. lusitanica. Subaequatorial section showing the pillared endoskeleton only in the central part of the test. This effect is due to the undulated surface of the test (sample VILL-VILL-3). f Rectocyclammina. Almost axial section (sample VILL-VILL-2B). g Subaxial section of Redmondellina powersi observed in the CLP of the DSR in the Benagéber area (dotted blue line). Note the presence of endoskeleton (sample AC1027). h-p LBF observed along the DSR in the Losilla-Alpuente area (yellow line): h-l CLP; $\mathbf{m}, \mathbf{n}$ SUP-1; $\mathbf{o}, \mathbf{p}$ SUP-3. $\mathbf{h}$ A. personata. Equatorial section of an A-form showing the structured septa and the empty chamber in the central part (no endoskeletal elements; sample AS-5). i Subaxial section of Kurnubia gr. palastiniensis cutting, successively, at the upper part the reticular subepidermal endoskeleton (beams and rafters) and at the lower part the columellar endoskeleton (sample AS-13). j Subaxial section of $R$. powersi. Note the presence of endoskeleton (sample AS-10). k Axial section of a small Feurtillia (sample AS-7). 1 Axial section of Andersenolina (sample AS-10). m Subequatorial slightly oblique section of A. personata-jaccardi (sample Co-Ti-3A). N) Subaxial section of A. personata-jaccardi (sample Co-AO-2). o Anchispirocyclina lusitanica. Oblique section showing the exoskeletal and endoskeletal elements and the septa pierced by numerous small foramina (sample ACLP-VILL-7E). p A. lusitanica. Subaxial section near to the axial of a B-form (sample ACLP-VILL7E). $\mathbf{q}, \mathbf{r}$ LBF observed in the CLP of the DSR in the Riodeva area (dotted green line): q Subaxial slightly oblique section of A. personata-jaccardi (sample RI-CB-7). $\mathbf{r}$ Traverse-oblique section of a Pseudocyclammina (sample RI-CB-4C-B). Scale bar in all sections: $0.2 \mathrm{~mm}$

(with shells of large bivalves as oncoid nuclei; Figs. 111, $12 \mathrm{~d})$ are scatteredly interbedded with siliciclastics.

The bioclastic and/or oolitic limestone beds of the CLP in the Riodeva section contain an LBF assemblage dominated by the occurrence of Alveosepta jaccardi-personata and Redmondellina, associated to Kurnubia gr. palastiniensis, Pseudocyclammina, Everticyclammina?, Mesoendothyra? and Nautiloculina (Figs. 3a, 8q, r). In the SUP, limestone beds of the Riodeva section contain unclassifiable small agglutinated forams (see T1SM for details); in the Villel town section we have observed in the bioclastic and/or oolitic limestone beds of the SUP, the occurrence of Everticyclammina? and Mesoendothyra? (Figure 3a), which are identical to those observed at the SUP of the DSR in the Losilla-Alpuente, Villar del Arzobispo and the Benagéber areas.

Regarding dinosaurs, in the Riodeva area, 58 dinosaur fossil sites have been inventoried in deposits of the SUP (see Fig. 3a for the probable stratigraphic position of the main dinosaur sites and T3SM for details and references), which have Jurassic affinities, and have been assigned to 


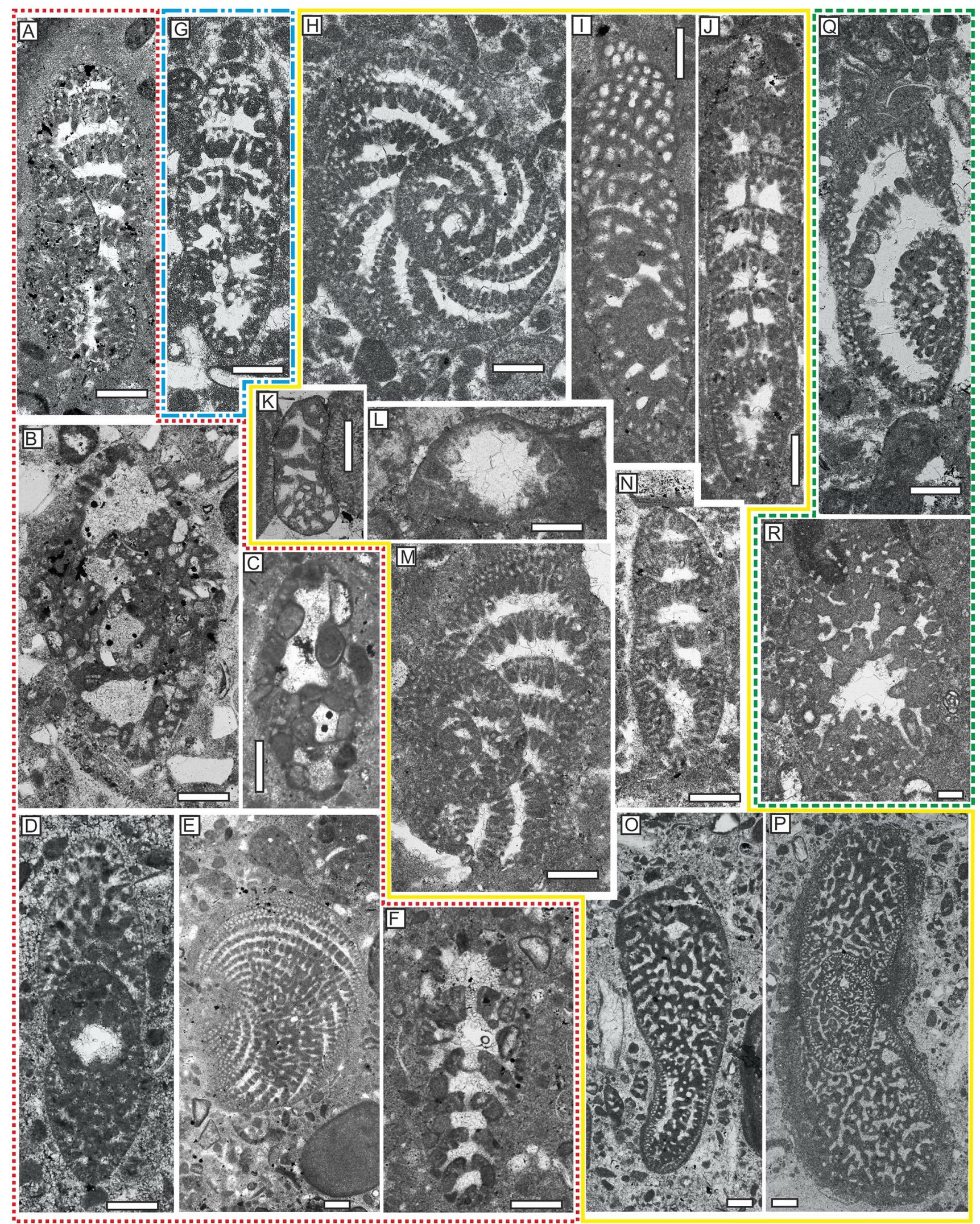


the Villar del Arzobispo Fm by Luque et al. (2005). Sauropods and stegosaurids are the most abundant. Among the sauropods, the turiasaurs, as Turiasaurus riodevensis (from the Barrionda-El Humero site; Fig. 12h) and other specimens from El Puntal de Santa Cruz site and San Lorenzo site (Royo-Torres et al. 2006, 2009; Cobos et al. 2011), and the diplodocoids (Royo-Torres et al. 2009) stand out. Most of the fossils of stegosaurids have been assigned to Dacentrurus (Cobos et al. 2010, 2014; Cobos and Gascó 2013). Ornithopods have been only found as isolated remains attributed to Ankylopollexia indet. (Gascó et al. 2013) and theropod fossils (mainly known from isolated teeth) have been assigned to dromaeosaurs, allosaurids and megalosaurids (Gascó et al. 2012; Cobos et al. 2014). In the Villel town area, few fragmentary bones and tracks have been observed in the siliciclastic deposits of the CLP (Pacios et al. 2018; Figs. 3a, 12f).

\section{Discussion}

Data presented in this work, which are discussed in the following sections, show that the DSR in all the studied areas, both of the western Maestrazgo and South-Iberian basins, shows similar ages, facies, facies distribution and evolution and fossil content (including LBF and dinosaurs).

\subsection{Revisiting the age of the studied dinosaur-bearing sedimentary record in eastern Spain}

\subsubsection{The age of the DSR in the western Maestrazgo Basin}

Bioclastic and/or oolitic limestone of the CLP of the DSR of the Las Zabacheras, Cedrillas and El Castellar sections contains an LBF assemblage dominated by Alveosepta jaccardi and Alveosepta personata (Figs. 3a, 6a-d), which indicate a Kimmeridgian age (e.g. Hottinger 1967, Pélissié et al. 1984; Bassoullet 1997; Campos-Soto et al. 2017a). In contrast, bioclastic and/or oolitic limestone of the uppermost part of SUP, observed in the Cedrillas, Formiche Alto, and Mora de Rubielos sections, contain a LBF assemblage dominated by Anchispirocyclina lusitanica, mainly associated with Chofatella cf. tingitana (Figs. 3a, 6e, f). Features observed in specimens of A. lusitanica of the studied samples are very similar to those reported in the specimens identified in some Tithonian deposits of Asturias (North Spain), which, in turn, contain similar morphotypes of $C$. cf. tingitana (González-Fernández et al. 2014). Anchispirocyclina lusitanica has been previously attributed to the Portlandian (Hottinger 1967; Pélissié et al. 1984) or, since the 90s, to the Tithonian (Septfontaine et al. 1991; Velic 2007), which is the age assigned to the deposits containing A. lusitanica of
Fig. 9 Photographs of the DSR in the Benagéber area (see Fig. 2 for location). a-d Photographs of the CLP of the DSR (see Fig. 3a for stratigraphic location). a Field aspect of the CLP comprising alternating bioclastic and/or oolitic limestone (blue arrows), and minor marl and sandstone (yellow arrows). b Oolitic limestone containing scattered echinoderm fragments (yellow arrow). c Bioclastic limestone containing LBF (blue arrows), SBF (miliolids, white arrows), and dasyclad green algae (red arrows). d Bioclastic limestone containing mollusk fragments, LBF (blue arrows), scattered echinoderm fragments (yellow arrow) and scattered ooids. e-n Photographs of the SUP of the DSR. e Decimeter-thick non-channelized plane- and cross-bedded sandstone alternating with marl. f Clast-supported and poorly-sorted channelized conglomerate mainly composed of angular to subangular reddish to yellowish soft clasts. $\mathrm{g}$ Meter-thick nonchannelized sandstone body displaying large-scale and low-angle cross-bedding. $\mathbf{h}$ Indeterminate vertebrate bone fragments observed within a meter-thick sandstone body. i Reddish siliciclastic mudstone overlain by a bioclastic limestone bed (blue arrow). $\mathbf{j}$ Thalassinoideslike burrow traces in limestone bed shown in i. k Field photograph of a sandy limestone containing abundant bivalve fragments. I Bioclastic limestone containing mollusk fragments, ostracods, benthic foraminifera, quartz grains and scattered ooids. m Bioclastic sandy limestone containing mollusk fragments, peloids, ostracods and charophytes (green arrows). n Peloidal limestone containing quartz grains and scattered SBF (white arrow)

the uppermost part of the Villar del Arzobispo Fm (uppermost part of the SUP; Figs. 3a, 6e, f) by Campos-Soto et al. (2017a). Therefore, the LBF assemblages observed in the CLP and the SUP indicate a Kimmeridgian-Tithonian age for deposits of the DSR, at least in the western Peñagolosa sub-basin (Fig. 3b).

However, in the Galve sub-basin, and specially, in the "Las Zabacheras" section, the age of the studied deposits is controversial (Fig. 3a, b; T1SM for details). In this area, Díaz-Molina et al. $(1984,1985)$ and Díaz-Molina and Yébenes (1987) studied the Upper Jurassic-Lower Cretaceous sedimentary record at the "Las Zabacheras" area and divided it into 6 informal units (U1 to U6). Specifically, $\mathrm{U} 2$, essentially carbonate, and U3, essentially siliciclastic, correspond to the CLP and the SUP of the DSR, respectively (Fig. 3a, b). Deposits of U2 were assigned to the Portlandian (Díaz-Molina et al. 1984, 1985; Díaz-Molina and Yébenes 1987) and to the Tithonian-Berriasian (Aurell 1990; Aurell and Meléndez 1993; Ruiz-Omeñaca et al. 2004; Canudo et al. 2012; Aurell et al. 2016). Royo-Torres et al. (2014) interpreted an age of Late Tithonian-Berriasian for U2 plus U3, proposing a possible Early Berriasian age for U3. Recently, a Kimmeridgian age has been assigned to U2 by Santos et al. (2018) and Delvene et al. (2019) and to the lowermost part of U2 by Val et al. (2019), which confirms the Kimmeridgian age obtained by Campos-Soto et al. (2017a) for the CLP of the DSR in the western Peñagolosa sub-basin and that obtained in this work for the CLP of Las Zabacheras section, based on the occurrence of Alveosepta jaccardi and A. personata (Figs. 3a, b, 6a, b). Moreover, A. jaccardi and A. personata have been observed 

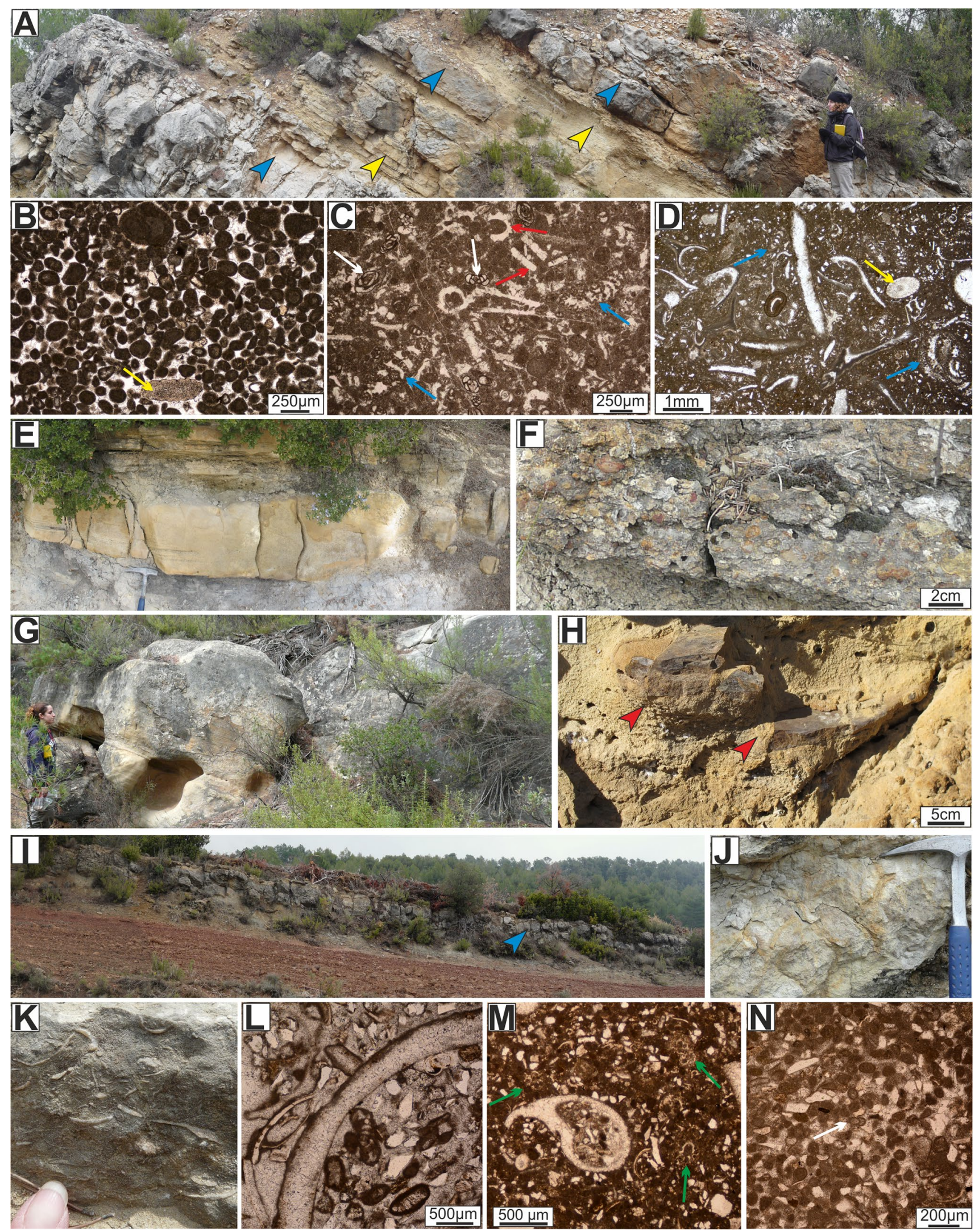
in this work above the stratigraphic position where Val et al. (2019) establish the Kimmeridgian-Tithonian limit in the area, implying that this limit, if it was included in deposits of the CLP, should be established in a higher stratigraphic position than that interpreted by Val et al. (2019) on the basis of the last occurrence of Alveosepta jaccardi observed by these authors.

In the SUP of the DSR of Las Zabacheras section (equivalent to U3; Fig. 3a, b), where Aragosaurus ischiatus was found, we could not obtain foraminifera with chronostratigraphic value. U3 has been assigned (Fig. 3b; T1SM for details) to the Berriasian-Hauterivian? (Diaz-Molina et al. 1984, 1985), to the Hauterivian? (Díaz-Molina and Yébenes 1987; Soria 1997), to the Valanginian-Hauterivian (Canudo et al. 2012) and to the Middle Berriasian-Early Valanginian? (see Fig. 14 of Aurell et al. 2016 and T1SM for details). Recently, Santos et al. (2018) have questioned the ages proposed by Aurell et al. (2016) and have suggested a Berriasian age for U3, based on palynological data, although they do not discard an older age (Fig. 3b; T1SM for details).

Therefore, the age of the DSR in the western Maestrazgo Basin is Kimmeridgian-Tithonian, or, locally, Kimmeridgian-Early Berriasian? in the Las Zabacheras-Galve area, based on LBF and pollen associations. This Late Jurassic age is also reinforced by the dinosaur fossils found in the DSR, which show a strong Late Jurassic affinity, such as the stegosaur Dacentrurus, the diplodocids or the megalosaurids (e.g. Cobos et al. 2010, 2014, 2015; Cuenca-Bescós et al. 1997; Sanchez-Hernández et al. 2007; see previous sections and T3SM for more details).

\subsubsection{The age of the DSR in the South-Iberian Basin}

LBF assemblage observed in the bioclastic and/or oolitic limestone beds of the CLP of the DSR, which contain Redmondellina (ex-Alveosepta) and/or Alveosepta (Figs. 3a-b, $8 \mathrm{a}, \mathrm{g}, \mathrm{h}, \mathrm{j}-\mathrm{q})$, is very similar to that observed in the CLP of the DSR in the western Maestrazgo Basin, indicating a Kimmeridgian age as well (e.g. Hottinger 1967, Pélissié et al. 1984; Bassoullet 1997; Campos-Soto et al. 2016a). Moreover, Alveosepta jaccardi-personata and Redmondellina powersi have been observed, for the first time, in bioclastic and/or oolitic limestone of the SUP-1 in the Losilla-Alpuente area (Figs. 3a, 8m, n), which indicates a Kimmeridgian age for deposits of the SUP-1, at least, in that area. The Kimmeridgian age determined for deposits of the SUP-1 contrast with the Hauterivian-Early Aptian or Late Hauterivian?-Early Barremian ages previously assigned to these deposits by González Lodeiro et al. (1975) and Vilas et al. (1982a), respectively, and precises interpretations made by Casanovas-Cladellas et al. (1999), Santisteban and Suñer (2002), Luque et al. (2005), Royo-Torres et al. (2006), Santisteban and Esperante (2005) and Santisteban
Fig. 10 Photographs of the DSR in the Losilla-Alpuente area (see Fig. 2 for location). a-c Photographs of the CLP of the DSR (see Fig. 3a for stratigraphic location). a Field photograph of alternating bioclastic and/or oolitic limestone (blue arrow), marl and non-channelized sandstone (yellow arrow). b Bioclastic limestone with abundant LBF (blue arrows), SBF (white arrows), and scattered ooids. c Oolitic limestone. d-l Photographs of the SUP of the DSR. d Meterthick, non-channelized sigmoidal cross-bedded sandstone (red arrow) interbedded with reddish siliciclastic mudstone of the SUP-2. e Dinosaur track (probably theropod) observed in the "Corcolilla" fossil site, located in a meter-thick sandstone body of the SUP-2. f Alternating reddish siliciclastic mudstone, bioclastic and/or oolitic limestone (blue arrows) and channelized sandstone (yellow arrow) of the SUP1. g-i Photomicrographs of limestone of the SUP-1. g Oolitic limestone containing some LBF (blue arrow) and mollusk fragments. $\mathbf{h}$ Bioclastic limestone composed of bivalve fragments (some of them ostreids), gastropods, SBF (white arrow) and quartz grains. i Peloidal limestone containing scattered SBF (white arrows). $\mathbf{j}-\mathbf{l}$ Limestone of the SUP-3. j Bioclastic limestone bed alternating with reddish siliciclastic mudstone. $\mathbf{k}$ Detail of a sandy bioclastic limestone containing abundant bivalve fragments (compare with Fig. 9k). I Peloidal and bioclastic limestone containing LBF and SBF (blue and white arrows, respectively), bivalve fragments, and small ooids

and Santos-Cubedo (2010), who have assigned these deposits to the Jurassic-Cretaceous transition based on the occurrence of dinosaur fossils with Jurassic affinities (see Fig. 3a, $\mathrm{b}$ and T1SM and T3SM for references and details).

The SUP-3 of the Villar del Arzobispo and the LosillaAlpuente areas contains a LBF assemblage dominated by Anchispirocyclina lusitanica, which is similar to that observed in the uppermost part of the SUP of the DSR in the western Peñagolosa sub-basin (Figs. 3a, 8d-f, o, p; see Sects. 4.1 and 5.1.1), and has been observed for the first time in these areas. As well as interpreted in the western Maestrazgo Basin, the occurrence of A. lusitanica indicates a Tithonian age (e.g. Septfontaine et al. 1991; Velic 2007; Campos-Soto et al. 2017a). The Tithonian age obtained for deposits of the SUP-3 contrasts with the Hauterivian-Early Aptian or Late Hauterivian?-Early Barremian ages previously assigned in the Losilla-Alpuente area to these deposits by González Lodeiro et al. (1975) and Vilas et al. (1982a), respectively, and also contrasts with the Aptian-Albian age assigned by Lazuen et al. (1977), Mas (1981) and Mas and Alonso (1981) to deposits of the SUP-3 cropping out in the Villar del Arzobispo section (see Fig. 3a, b and T1SM for references and details).

It was not possible to observe any fossil with chronostratigraphic significance in deposits of the SUP of the Benagéber, Riodeva or the Villel town areas. However, the presence of Anchispirocyclina lusitanica in deposits of the SUP-3 of the Losilla-Alpuente and the Villar del Arzobispo areas (Fig. 3a, b), together with data provided by the dinosaur fauna, which have Jurassic affinities, such as Dacentrurus, the diplodocids and the megalosaurids in the Riodeva and Losilla-Alpuente areas (e.g. Casanovas-Cladellas et al. 1999; Maidment et al. 2008; Royo-Torres et al. 2009; Cobos 


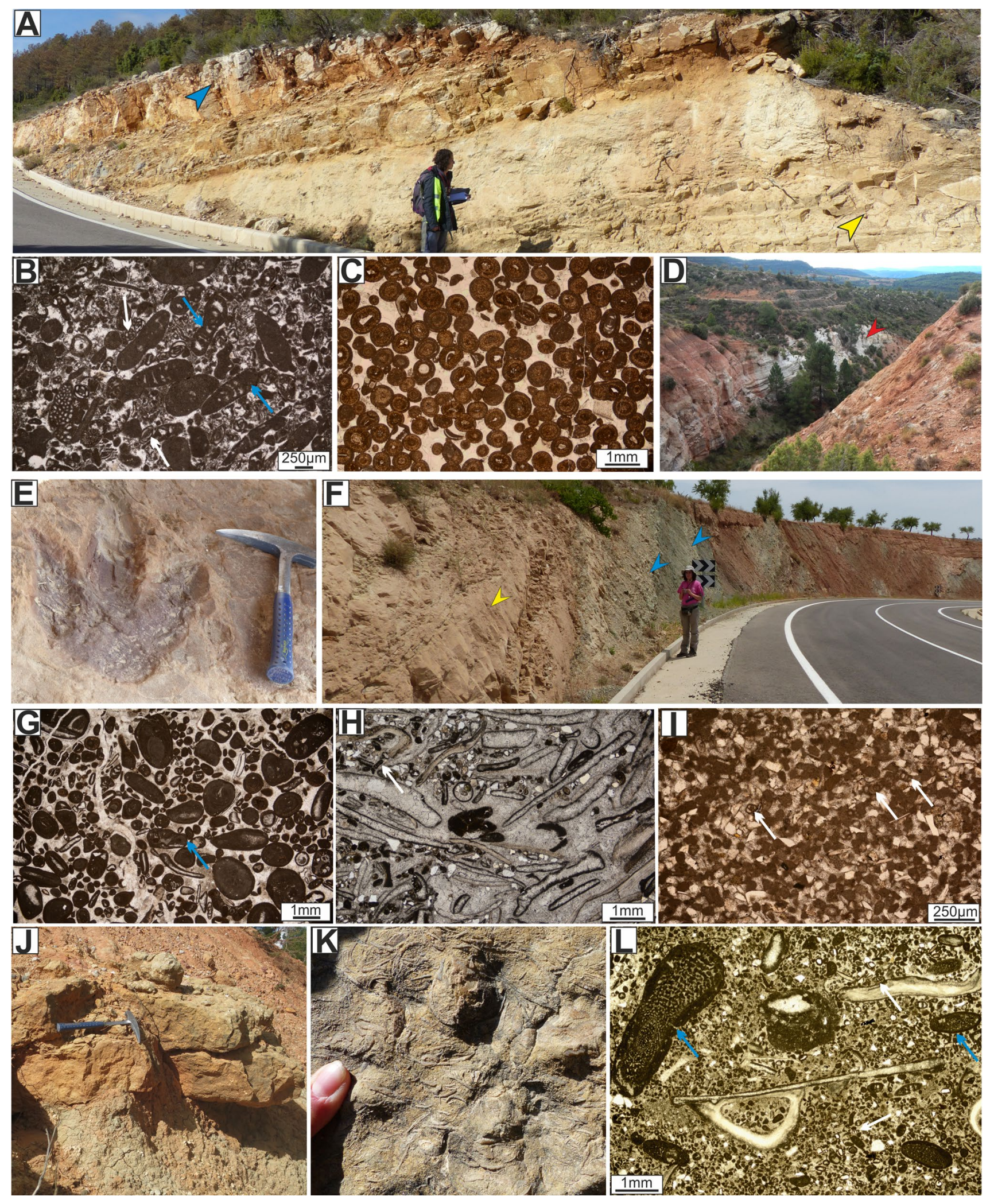


et al. 2010, 2014; see previous sections for details and T3SM for more details), and the sauropod tooth, similar to those of "Neosodon" of the Upper Jurassic of France (Royo-Torres et al. 2006) in the Benagéber area, also confirm a Kimmeridgian-Tithonian age for the DSR in the South-Iberian Basin.

\subsection{Revisiting the lithostratigraphic framework of the studied dinosaur-bearing sedimentary record in eastern Spain}

\subsubsection{The lithostratigraphic framework of the DSR in the western Maestrazgo Basin}

In this work and, in accordance with many authors (e.g. Hernández et al. 1985; Aurell 1990; Aurell et al. 1994; Aurell and Meléndez 1993; Bádenas et al. 2004; Alcalá et al. 2009, 2014a, 2014b; Bádenas and Aurell 2010; Cobos et al. 2010, 2014; Mampel et al. 2010-2011; Royo-Torres et al. 2014; Campos-Soto et al. 2017a; Santos et al. 2018; Delvene et al. 2019), it is interpreted that deposits of the DSR should be included in the Villar del Arzobispo Fm; in fact, the parastratotype of this formation was defined in the Cedrillas area (Figs. 2, 3a) by Mas et al. (2004).

However, recently, Aurell et al. (2016), Bádenas et al. (2018) and Val et al. (2019) have subdivided the deposits traditionally considered as belonging to the Villar del Arzobispo Fm in the Galve sub-basin (see references cited in the previous paragraph), in three formal units, which Aurell et al. (2016) extend to the western Peñagolosa sub-basin. These units are (Fig. 3b; T1SM): (a) the Villar del Arzobispo Fm, which, according to these authors, in the Las Zabacheras-Galve area correspond to most of the U2; (b) the Aguilar del Alfambra Fm, newly defined by Aurell et al. (2016). According to these authors this unit would correspond to the uppermost part of $\mathrm{U} 2$, and its lower limit corresponds to an erosive unconformity; (c) the Galve Fm, which crops out locally and it is newly defined by Aurell et al. (2016) as well. According to these authors the Galve Fm is equivalent to U3, in the Las Zabacheras-Galve area, and to the Mora de Rubielos Fm in the Formiche Alto and Mora de Rubielos sections (Figs. 1d, 3a), and its lower limit corresponds to a low-angle erosive unconformity.

However, the new units defined by Aurell et al. (2016) cannot be accepted because of several reasons: (i) their nomenclature and limits are not appropriate according to recommendations for establishing lithostratigraphic units of the International Stratigraphic Guide (ISG, Murphy and Salvador 1999), which recommends on page 258 (see T1SM for details): "If a unit is divided into two or more formal component units, the geographic name of the original unit should not be employed for any of the subdivisions" and this is the case of the Villar del Arzobispo Fm after subdividing it by Aurell et al. (2016); the ISG recommend that
Fig. 11 Photographs of the studied sedimentary record in the Riodeva area (see Fig. 2 for location). a-d Photographs of the CLP of the DSR (see Fig. 3a for stratigraphic location). a Field photograph showing the area where the section was logged: the CLP of the DSR, to the right, has relative high topographic relief, and is composed of alternating limestone beds, marl or siliciclastic mudstone and minor sandstone. The SUP is mainly composed of reddish siliciclastic mudstone, alternating with sandstone (commonly white or yellowish in colour), minor conglomerate, and scattered limestone. The location of some of the following photographs is shown: $\mathbf{b}, \mathbf{e}-\mathbf{i}, \mathbf{l}$. b Detail of the limit between the CLP and the SUP. c Oolitic and bioclastic limestone containing mollusk fragments. d Bioclastic sandy limestone containing abundant mollusk fragments (displaying micritic envelopes), LBF (blue arrow) and echinoderm fragments (yellow arrow). e-l Photographs of the SUP of the DSR. e Channelized sandstone in the Barrihonda-El Humero site (where Turiasarus riodevensis was found). f Meter-thick non-channelized well-sorted sandstone body displaying high-angle and large-scale cross-bedding (sets up to $2 \mathrm{~m}$ thick). g Non-channelized sigmoidal cross-bedded sandstone. Note the long bottomsets containing abundant carbonaceous detritus, whose content decreases upwards, along the lower part of the foresets. h Turiasaurus riodevensis fossils in the Barrihonda-El Humero type locality. $\mathbf{i}$ Bioclastic and oolitic limestone bed alternating with reddish siliciclastic mudstone and sandstone of the SUP. $\mathbf{j}$ Limestone composed of peloids, small ooids, bivalve fragments, scattered echinoderm fragments (yellow arrow), and plant remains (red arrow). k Peloidal limestone containing quartz grains and scattered SBF (white arrow). 1 Large oncoids. The nuclei of the oncoids are bivalve shells

"The name of a new stratigraphic unit should be unique in order to prevent ambiguity"; and there is a Galve Member, defined in the same area by Peropadre et al. (2012), for Aptian deposits. (ii) the age attributed to the new units by Aurell et al. (2016) does not correspond to the ages obtained by Campos-Soto et al. (2017a), Santos et al. (2018), Delvene et al. (2019), Val et al. (2019), and with those obtained in this work; (iii) according to page 260 of the ISG (Murphy and Salvador 1999): "Local or minor hiatuses, disconformities or unconformities within a sequence of similar lithologic composition should not be considered reason for recognition of more than one lithostratigraphic unit". In this regard, we interpret that the erosive unconformities described by Aurell et al. (2016) are, in fact, minor and local unconformities, similarly to that shown in Fig. 5e, and should not be used for defining formal units, as the ISG recommend. Data obtained in this work indicate that in the Galve area, located in the northwesternmost area, and further away from the Tethys Sea, the overall subsidence rate and the marine influence was smaller than in the southern Peñagolosa sub-basin. Thus, in the extensional context in which the DSR was deposited, synsedimentary faults and minor unconformities would be easily recognizable in areas where subsidence rate and sediment thickness is small, such as in the Las Zabacheras, Cedrillas and El Castellar areas, where minor unconformities (Fig. 5e) and synsedimentary faults have been observed since the onset of deposition (Royo-Torres et al. 2014; Aurell et al. 2016; Campos-Soto et al. 2017a). However, in the most 

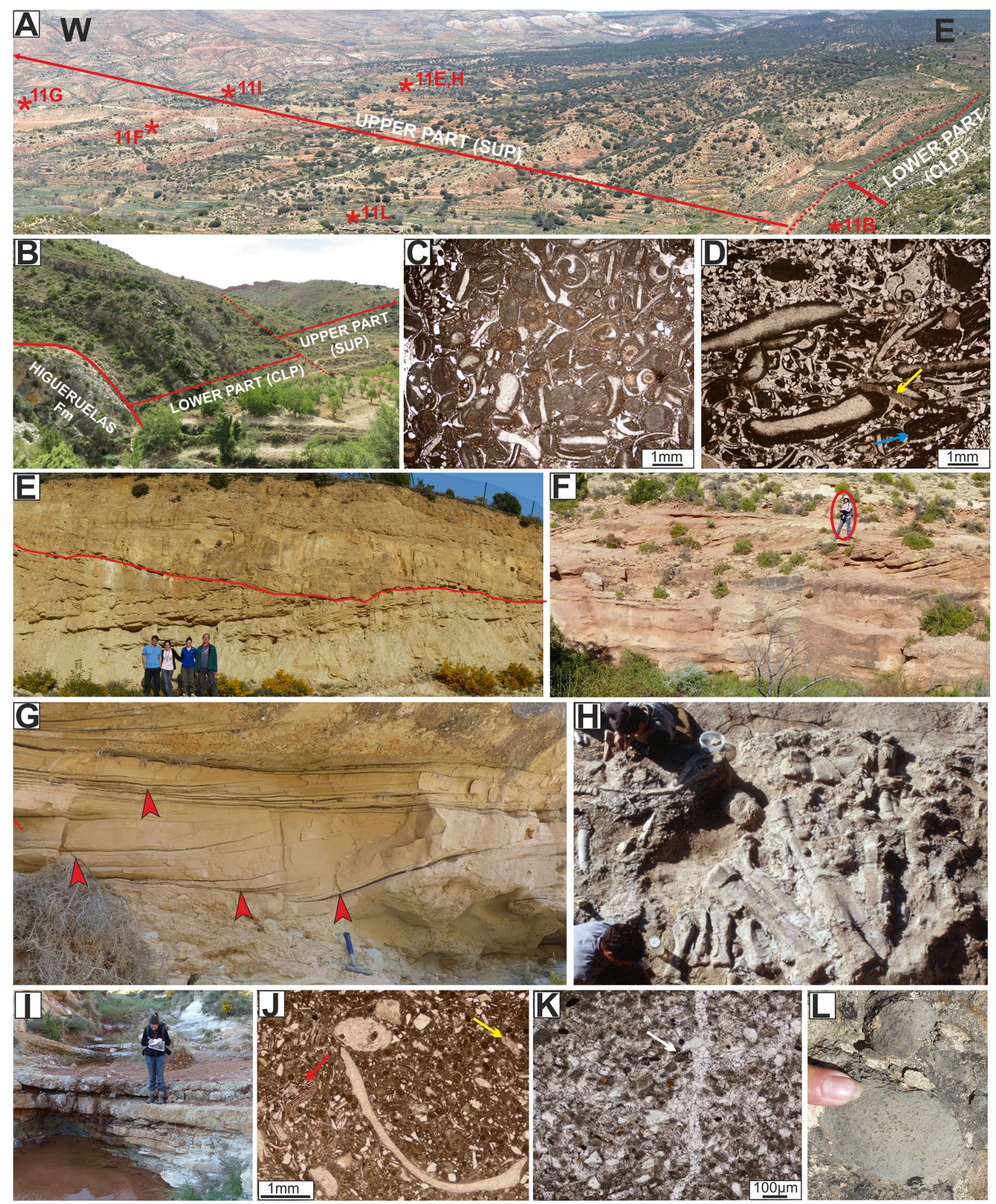
subsident areas, such as in the southern Formiche Alto section, synsedimentary faults and unconformities are not easily observable, as is commonly described in extensional sedimentary basins (e.g. Miall 1997, 2010; Einsele 2000). This interpretation is also reinforced by the similarity of the facies, lateral and vertical facies distribution, and fossil content (included dinosaur fossils) observed in all the studied areas of both the western Maestrazgo and the South-Iberian basins (see below).

\subsubsection{The lithostratigraphic framework of the DSR in the South-Iberian Basin}

Data presented in this work demonstrate that the DSR in all the areas is correlatable with deposits of the Villar del Arzobispo Fm cropping out in the western Maestrazgo Basin (Fig. 3a; Table 1), and specifically in the Cedrillas area, where the parastratotype of the unit was defined (Mas et al. 2004) and where this unit crops out exceptionally well and is properly dated from the base to the top; specifically: (a) deposits of the carbonate-dominated lower part (CLP) of the DSR in the South-Iberian Basin, originally assigned to the Villar del Arzobispo Fm (sensu Mas and Alonso 1981), are correlatable in facies and age (Kimmeridgian) only with those of the carbonate-dominated CLP of the Villar del Arzobispo Fm in the western Maestrazgo Basin (Fig. 3a, b; Table 1; T1SM); (b) deposits previously assigned to the Lower Cretaceous Aldea de Cortés and El Collado Fms (and locally, those previously assigned to the Aptian-Albian in the Villar del Arzobispo area) are correlatable in facies and age (Tithonian) with the siliciclastic-dominated deposits of the upper part (SUP) of the Villar del Arzobispo Fm in the western Maestrazgo Basin (Fig. 3a, b, Table 1; TSM1). Thus, we consider that the usage of the Aldea de Cortés and El Collado Fms of Vilas et al. (1982a), at least in the studied area, where these units were formally defined, should be avoided, and the limits, age, and the stratotype of the Villar del Arzobispo Fm, as defined by Mas et al. (1984; Fig. 3a, b), should be reviewed; in this sense, we consider that the parastratotype of the Villar del Arzobispo Fm at the Cedrillas area would be an excellent candidate for redefining the unit.

\subsection{Revisiting the sedimentary palaeoenvironments of the studied dinosaur-bearing sedimentary record and the Late Jurassic palaeogeography of eastern Spain}

As demonstrated above, the DSR in all the studied areas, both of the western Maestrazgo and South-Iberian basins, is very similar in age, facies, and facies evolution; however, it shows some differences, such as the thickness and proximal-distal facies distribution, which are associated with the extensional tectonics that affected Iberia during deposition in relation to the opening of the Western Tethys, to the E-SE and the North Atlantic, to the N and W (e.g. Salas et al. 2001; Alves et al. 2002; Mas et al. 2004; Pujalte et al. 2004; Pena dos Reis et al. 2010-2011; Kullberg et al. 2013, and references therein): the DSR in the areas located to the E-SE, close to the Tethys sea during deposition (Mora de Rubielos and Formiche Alto in western Maestrazgo Basin and Villar del Arzobispo and Losilla-Alpuente sections in South-Iberian Basin; Figs. 2, 13a), is thicker and has more limestone beds containing fully marine biota (Fig. 3a) than the DSR in the areas located towards the N and W (Las Zabacheras, Cedrillas and El Castellar, in the western Maestrazgo Basin, and Benagéber, Riodeva and Villel town areas in the South-Iberian Basin), where, in contrast, the occurrence of minor unconformities and abundant subaerial exposure features is common (Figs. 3a, 5e).

Despite these differences, and in accordance with previous authors (see the Geological setting section), the general sedimentary evolution observed in the DSR of all the studied areas is overall regressive (Fig. 3a; Table 1). In all the areas the CLP was deposited during the Kimmeridgian in a shallow to very shallow inner carbonate platform-lagoon, which was connected with a coastal and alluvial plain to the $\mathrm{N}$ and W (Fig. 13), and underwent the arrival of siliciclastics by ephemeral currents coming from the emergent areas. In this context, marine influence was higher towards the areas located towards the E-SE, as evidenced by the abundance of limestone beds, which in turn, contain fully marine biota, even corals in life position (Fig. 3a, Table 1). In contrast, towards the $\mathrm{N}$ and $\mathrm{W}$, freshwater and continental influence progressively increased, as evidenced by the decrease of limestone beds, which, in turn, contain charophytes and scarce marine fossils, and by the abundant evidences of subaerial exposure, such as edaphic features and dinosaur tracks (Fig. 3a).

Marine influence progressively decreased upwards, and the essentially siliciclastic sediments of the SUP were deposited during the Kimmeridgian-Tithonian in a coastal and alluvial plain connected, to the E-SE, with shallow and tide-influenced marine areas (coastal wetland system sensu Suarez-Gonzalez et al. 2015; Figs. 3a, 13). According to palaeocurrent data, marine areas were located to the E-SE while siliciclastics arrived from the emergent areas, located to the $\mathrm{N}$ and $\mathrm{W}$ (Figs. 3a, 13; Table 1); moreover, local source areas were located where the Javalambre Range is nowadays, which coincides with the position where the Valencian Massif was located during deposition (Fig. 1b, c, 13a, b; Mas 1981; Mas and Alonso 1981; Mas et al. 2004). Siliciclastic sediments were mostly deposited under subaqueous conditions (Table 1): reddish siliciclastic mudstone was deposited in flood plains, which underwent periodical 

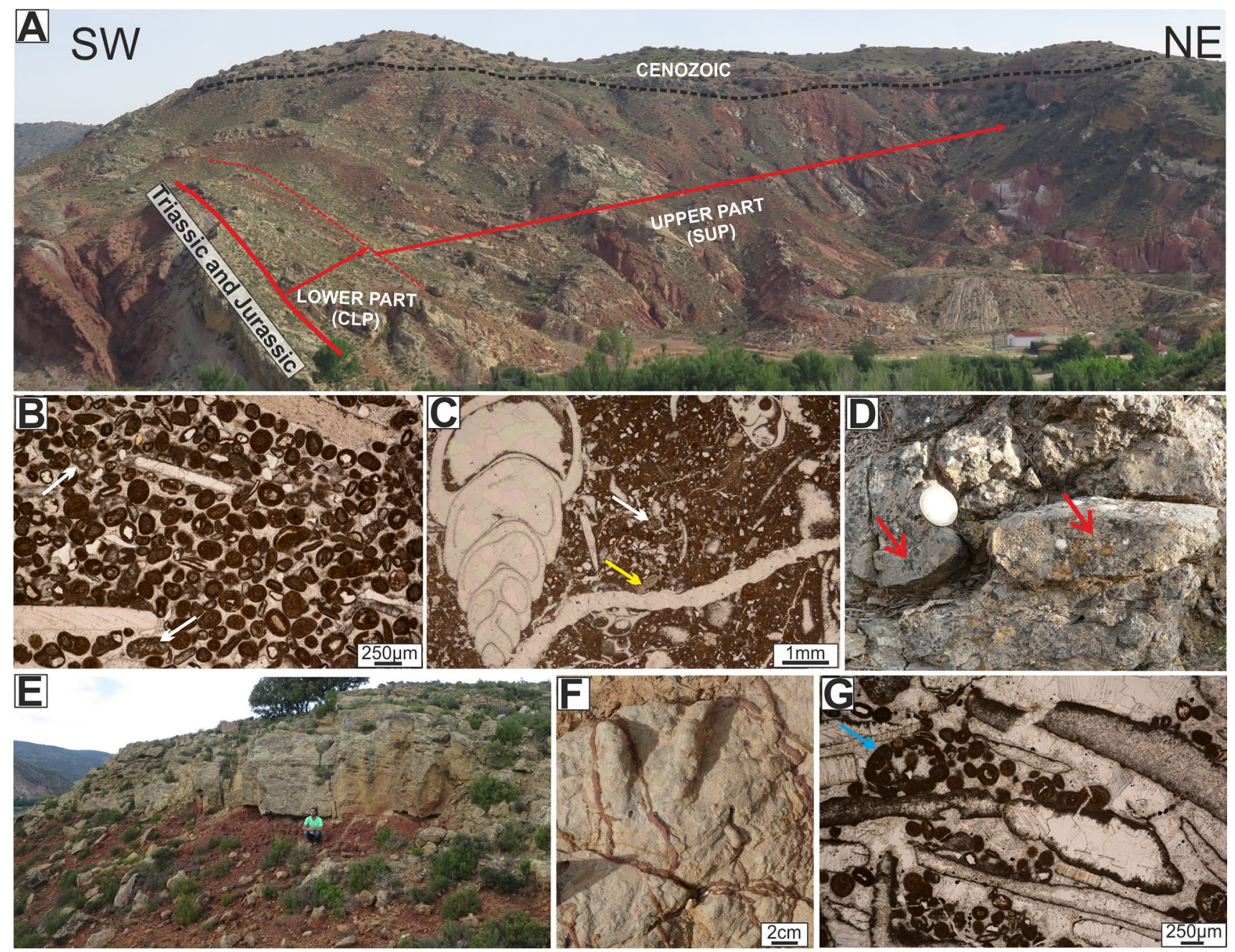

Fig. 12 Photographs of the DSR in the Villel town area (see Fig. 2 for location). a Field photograph showing the area where the section was logged (see Figs. 2 and 3a for geographic and stratigraphic locations, respectively): the CLP to the left, is composed of alternating reddish siliciclastic mudstone, sandstone and limestone; the SUP, to the right, is mainly composed of reddish siliciclastic mudstone alternating with white to yellowish sandstone and minor conglomerate. b-d Photographs of the CLP of the DSR. b Oolitic limestone containing mollusk fragments and scattered SBF (white arrows). c Oolitic and bio- clastic limestone composed of small ooids, gastropods, SBF (white arrow) and scattered echinoderm fragments (yellow arrow). d Limestone containing large oncoids (red arrows). The nuclei of the oncoids are large bivalve shells. e-g Photographs of the SUP of the DSR. e Meter-thick channelized sandstone body, displaying large-scale crossbedding, interbedded with reddish siliciclastic mudstone. f Theropod? track. $\mathrm{g}$ Bioclastic limestone containing mollusk fragments, ooids and LBF (blue arrow)

medium-grained sandstone, displaying high-angle crossbedding, with sets up to $6 \mathrm{~m}$ thick (Figs. $9 \mathrm{~g}, 11 \mathrm{~b}$ ), is interpreted as aeolian dunes (Campos-Soto et al. 2015, 2016a, 2017b), as it is commonly interpreted in equivalent modern and ancient aeolian deposits (e.g. Mckee 1966; Mountney 2006; Rodríguez-López et al. 2008).

Siliciclastics deposited in the coastal and alluvial plain were laterally related to limestone deposition (Figs. 3a, 13a; Table 1). Towards the $\mathrm{W}$ and $\mathrm{N}$, in the areas located further away from the sea, limestone was deposited in shallow to very shallow water bodies with both marine and freshwater inputs because it may contain few fully marine Legler et al. 2013). Non-channelized well-sorted and fine- to 
fossils, such as echinoderms, as well as euryhaline (SBF) and freshwater fossils (charophytes), relatively abundant quartz grains, and abundant subaerial exposure features, such as desiccation cracks and dinosaur tracks. Moreover, in the areas located towards the E-SE, relatively close to the Tethys Sea, limestone containing abundant fully marine biota, even corals in life position, were progressively more abundant, indicating that deposition took place in a shallow to very shallow inner carbonate platform-lagoon (Figs. 1c, 3a, 13a; Table 1).

Towards the uppermost part of the DSR, limestone containing abundant marine biota, commonly including $A$. lusitanica, is observed in the studied areas located to the E-SE (Cedrillas, El Castellar, Formiche Alto and Mora de Rubielos, in the western Maestrazgo Basin, and Villar del Arzobispo and Losilla-Alpuente, in the South-Iberian Basin, Fig. 3a). This increase of marine limestone was interpreted in the western Maestrazgo Basin as a transgressive episode that occurred during the Tithonian by Campos-Soto et al. (2016b; 2017a) and, for the first time, this transgressive episode is also recorded in the South-Iberian Basin in this work.

\subsection{Correlation of the DSR with other Kimmeridgian-Tithonian dinosaur-bearing sedimentary record of Iberia: implications for Iberian palaeogeography}

The studied sedimentary record has been traditionally assigned to the Jurassic-Cretaceous transition (such as the deposits previously assigned to the "Purbeck" or to the Villar del Arzobispo Fm), and thus, it has been correlated with other units of the Iberian Basin assigned to the Tithonian-Berriasian, such as those of the Cameros Basin (Fig. 1; Salas et al. 2001; Mas et al. 2004). However, data presented in this work indicate that the DSR should be correlated with Kimmeridgian-Tithonian deposits. Based on data presented in this work and on those obtained from literature about coeval deposits of the Iberian Peninsula (Fig. 13), during the KimmeridgianTithonian, wide coastal and alluvial plains and shallow to very shallow marine areas developed to the west (Lusitanian Basin), north (Asturian and Cameros basins), east of Iberia (the DSR), which were very suitable for the development of dinosaurs and other vertebrates, and which have large similarities in sedimentary features and dinosaur fossils, as described below. Moreover, to the south of Iberia, in the South Iberian Paleomargin, represented by the Prebetic (External Zone of the Betics), coastal, alluvial and shallow marine environments also developed (e.g. Arias 1978; Vilas et al. 1982b, 2001, 2004; Martín-Chivelet et al. 2002) although, to our knowledge, dinosaur remains have not been recorded.

Moreover, the older ages demonstrated here for these Spanish dinosaurs reinforces the hypothesis that dinosaur assemblages of North America and Western Europe at the
Fig. 13 a Idealized reconstruction of the shallow marine and the coastal wetland system palaeoenvironments, inhabited by dinosaurs, during deposition of the upper part of the DSR. The location of the studied areas is shown: ZA (Las Zabacheras-Galve), CE (Cedrillas), CAS (El Castellar), FA (Formiche Alto), MO (Mora de Rubielos), VI (Villel), RI (Riodeva), LO (Losilla), AL (Alpuente), BE (Benagéber) and VA (Villar del Arzobispo). B) Palaeogeographic reconstruction of Iberia during the Tithonian (modified from Thierry et al. 2000b). Palaeogeography and palaeocurrents of the different areas of Iberia represented in the figure are based on data obtained from the following references: (1) Lusitanian Basin: Leinfelder and Wilson (1998); Pena dos Reis et al. (2000, 2010-2011) and Thierry et al. (2000b); (2) Asturias Basin: Valenzuela et al. (1986); García-Ramos and Gutierrez-Claverol (1995); García-Ramos et al. (2000); Thierry et al. (2000b) and González-Fernández et al. (2014); (3) Cameros Basin and most of the Maestrazgo Basin: Canérot (1974); Salas (1987); Salas et al. (2001); Mas et al. (2004) and Quijada et al. (2013); (4) South-Iberian and western Maestrazgo basins (studied area): data provided in this work

end of the Jurassic show strong similarities in their environmental context and phylogenetic relationships (i.e. Escaso et al. 2007; Lockley et al. 2008; Royo-Torres et al. 2009; Cobos et al. 2010, 2014; Mocho et al. 2017a).

\subsubsection{The Kimmeridgian-Tithonian sedimentary record of the Cameros Basin}

The Cameros Basin, which was located further away from the sea than the studied areas (Figs. 1, 13b), has a Kimmeridgian sedimentary record which is constituted by a prograding coral-bearing and oolitic unit, the Torrecilla en Cameros Fm, dated as Early Kimmeridgian based on ammonites and corals (Benke et al. 1981; Conze et al. 1984; Errenst 1990, 1991). The top of this unit corresponds to an erosional unconformity associated to karstification, which probably developed during the Late Kimmeridgian (Benito et al. 2001, 2005; Benito and Mas 2002; 2006). Units overlying the unconformity correspond to those of the Tera Group to the E, and those of the Tierra de Lara Group to the W, which are assigned to the Tithonian-Early Berriasian and to the Kimmeridgian?-Berriasian, respectively, and were deposited in alluvial and lacustrine-palustrine systems with minor or no marine influence (Tischer 1966; Platt 1989; Gómez-Fernández and Meléndez 1994; Martín-Closas and Alonso-Millán 1998; Salas et al. 2001; Schudack and Schudack 2009; Mas et al. 2004, 2011; 2019). In the Tera Group, very scattered bones of dinosaurs (Canudo et al. 2010), and scarce dinosaur tracks (i.e. Moratalla and Hernán 2010; Pascual-Arribas and Hernández-Medrano 2016; Hernández-Medrano et al. 2017) have been described. If the ages assigned to these deposits are accurate, they would be the only ones correlatable with those of the SUP of the DSR. Nevertheless, deposits of the Oncala Group, which overlie those of the Tera Group and have traditionally been assigned to the Berriasian, are especially rich in dinosaur tracks and it 


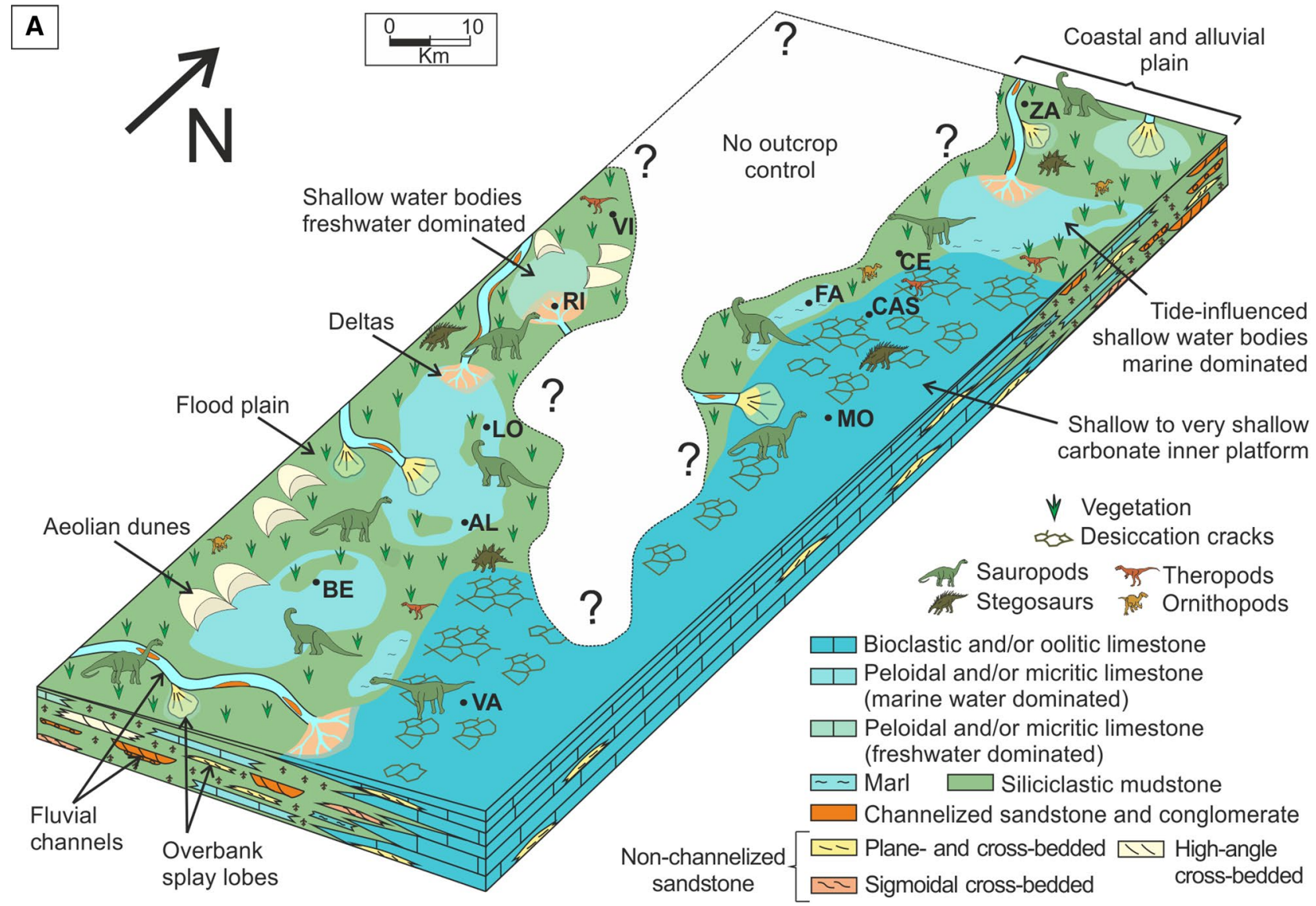

\section{B}

Deep marine facies

Shallow marine facies

Coastal facies (coastal, alluvial, tidal flat environments)

Continental facies (alluvial,

fluvial and lacustrine environments, local minor marine influence)

SIB South-Iberian Basin

MB Maestrazgo Basin

CB Cameros Basin

VM Valencian Massif $\diamond$ Studied area

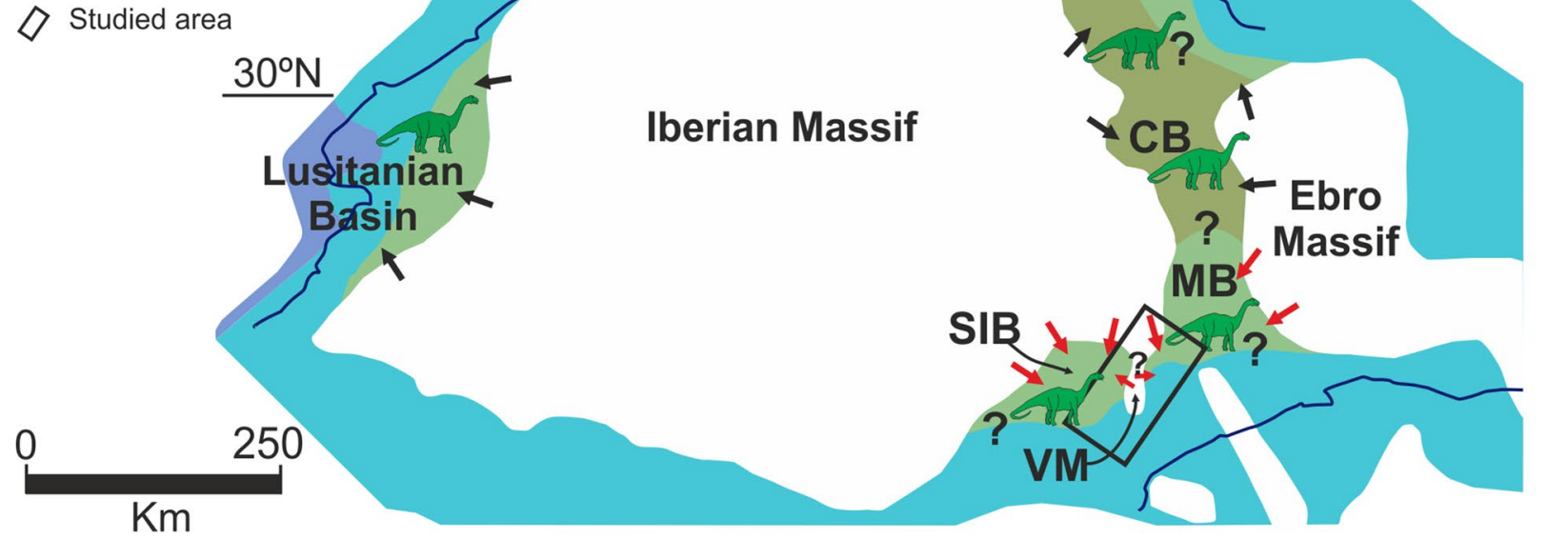


should be noted that the morphology of the sauropod, theropod, ornithopod and thyreophoran tracks is very similar to those of the DSR at the Maestrazgo Basin (i.e. Moratalla and Hernán 2010; Castanera et al. 2012, 2014, 2016; Pascual et al. 2012; Cobos et al. 2015; Pascual-Arribas and Hernández-Medrano 2015).

\subsubsection{The Kimmeridgian-Tithonian sedimentary record of the Asturian Basin}

In the Asturias Basin (Figs. 1, 13B), the Upper Jurassic dinosaur-bearing deposits belong to the Ribadesella Group, which has been subdivided in four formations: La Nora, Vega, Tereñes and Lastres Fms (Valenzuela et al. 1986). The latter three contain abundant dinosaur fossils (García-Ramos and Valenzuela 1977a, b; García-Ramos and GutiérrezClaverol 1995; García-Ramos et al. 2000, 2002, 2004, 2006), and were deposited in coastal and alluvial systems, similarly to what occurred in the studied areas. The siliciclastic Vega Fm was deposited in alluvial fans and in meandering fluvial systems (Valenzuela et al. 1986, 1988; Pujalte et al. 2004; González-Fernández et al. 2014), and has been assigned to the Kimmeridgian (Suárez Vega 1974; Pujalte et al. 2004) or to the Late Oxfordian-Late Kimmeridgian (Schudack and Schudack 2002). The Tereñes Fm, essentially carbonate, has been interpreted as deposited in a lagoon (Valenzuela et al. 1986; Fürsich et al. 2012) or in a muddy coast to shallow inland sea (González-Fernández et al. 2014), and has been assigned to the Kimmeridgian (Suárez Vega 1974; Schudack and Schudack 2002) or to the Kimmeridgian-Portlandian (Ramírez del Pozo 1969). The Lastres Fm, which is laterally and genetically related to the Tereñes Fm in its lower part, is mixed carbonate-siliciclastic and has been interpreted as deposited in small fluvio-deltaic systems that run into a restricted lagoon (Valenzuela et al. 1986; García-Ramos et al. 2002, 2004, 2006; González-Fernández et al. 2014). The Lastres Fm has been assigned to the Kimmeridgian (Suárez Vega 1974; Oloriz et al. 1988; Pujalte et al. 2004), or to the Kimmeridgian-Early Tithonian (Schudack and Schudack 2002; Pujalte et al. 2004).

In these units, dinosaur and other vertebrate remains, mainly ichnites of non-avian and avian theropods, ornithopods, sauropods and stegosaurids, are abundant (García Ramos et al. 2004 and references therein; Avanzini et al. 2012; Piñuela et al. 2016). These fossils have a very close phylogenetic relationship with those of the DSR in Eastern Spain. An example of this is the presence in Asturias of bones of the stegosaurid Dacentrurus (Ortega et al. 2006), cranial fossils of Turiasauria (Canudo et al. 2010; Royo-Torres et al. 2012) and tracks of the ichnogenus Deltapodus, among others (i.e. Lockley et al. 2008).

\subsubsection{The Kimmeridgian-Tithonian sedimentary record of Portugal}

The stratigraphic framework of deposits containing the Upper Jurassic dinosaur remains (both ichnites and bones) of the Lusitanian Basin is complex because it was tectonically active at that time and because of the changes in proximal (continental) to distal (marine) depositional palaeoenvironments (e.g. Taylor et al. 2014 and references therein): coastal to marine deposits predominated towards the distal SSW areas, whereas, towards the NNE, fluvial and/or coastal proximal deposits were deposited. Proximal facies progressively prograded onto the more distal ones, although several transgressive episodes have been described along the sequence. Most vertebrate remains have been found in the central sectors of the basin (Lourinhã and Guimarota areas; Antunes and Mateus 2003), in deposits consisting of reddish siliciclastic mudstone alternating with sandstone and minor marine limestone, which have been interpreted as deposited in fluvial, fluvio-deltaic, coastal or in the fluvial-tidal transition palaeoenvironments (Wilson 1979; Hill 1989; Leinfelder and Wilson 1989, 1998; Leinfelder 1993; Ravnås et al. 1997; Pena dos Reis et al. 2000, 2010-2011; Martinius and Gowland 2011; Myers et al. 2012; Taylor et al. 2014; Mocho et al. 2017a). The Upper Jurassic deposits of the basin have been dated, based on the occurrence of LBF (such as Alveosepta jaccardi or Anchispirocyclina lusitanica) and other marine biota, as Late Kimmeridgian-Tithonian, although a Middle Kimmeridgian to earliest Berriasian ages have been interpreted by some authors (see Taylor et al. 2014 and references therein for details). This sedimentary record has very similar sedimentary features, sedimentary evolution and age to those of the DSR: in both areas, shallow marine carbonates are progressively overlain by essentially siliciclastic coastal and alluvial deposits, representing an overall prograding sequence, with some transgressive episodes.

Moreover, the Upper Jurassic dinosaur faunas of the Lusitanian Basin are similar to those recorded in the DSR of the western Maestrazgo and South-Iberian Basins. In the Lusitanian Basin, dinosaurs belong to groups of sauropods, theropods, ornithopods and thyreophorans, which have a very close phylogenetic relationship with those of the DSR in Eastern Spain. For example, regarding bones, the direct remains of sauropods, non-neosauropods eusauropods include fauna with primitive affinities, such as Zby atlanticus (Mateus et al. 2014), which is similar to Turiasaurus riodevensis found in deposits of the Villar del Arzobispo Fm in Riodeva (Royo-Torres et al. 2006). Among the neosauropod fauna, diplodocids have also been described, including the species [Dinheirosaurus lourinhanensis (Bonaparte and Mateus 1999)], the basal macronarian, such as the taxa Lourinhasaurus alenquerensis (Dantas et al. 1998; Mocho et al. 2014), which is very close to the genus Camarasaurus, 
and a basal titanosauriform, Lusotitan atalayensis (Antunes and Mateus 2003; Mocho, et al. 2017b and references therein). Two of the dinosaur taxa defined in the Galve area, (Fig. 3b; see Sect. 4.1) are phylogenetically very close to the Kimmeridgian-Tithonian dinosaurs of Portugal (Mocho et al. 2014, 2017a, b; Royo-Torres et al. 2014, 2017). For example, Galveosaurus herreroi, clasified as Titanosauriformes (Mocho et al. 2017a, b) is very close to Lusotitan atalayensis, and Aragosaurus ischiaticus is very similar to the macronarian Lourinhasaurus alenquerensis.

In Portugal, fossils of medium- and large-size theropods belong to primitive clades, such as Ceratosauria and Tetanura (Megalosauridae y Allosauroidea), and the smallersized theropods are represented by more derived groups, such as Coelurosauria (Malafaia 2017 and references therein). Nevertheless, and despite the scarce record of direct remains of theropods in the Late Jurassic dinosaur-bearing sedimentary record studied in this work, it can be confirmed in these deposits the presence of theropods very similar to those of Portugal, such as the teeth assigned to megalosaurids and allosaurids (Cobos et al. 2014 and references therein), and those of Asturias (Rauhut et al. 2018). Another dinosaur that confirms the close phylogenetic relationships between the DSR and the sedimentary record of Portugal is the presence of the stegosaurid Dacentrurus (Cobos et al. 2010; Cobos and Gascó 2013; Escaso 2014, among others).

\section{Conclusions}

In this work, and for the first time, an integrated stratigraphic, palaeontological, palaeoenvironmental and palaeogeographical study of the dinosaur-bearing Upper Jurassic-Lower Cretaceous sedimentary record in eastern Spain (western Maestrazgo and South-Iberian basins) is accomplished. New data obtained in this work have allowed to demonstrate that:

1. The studied dinosaur-bearing sedimentary record has a Kimmeridgian-Tithonian age and, locally, in the Las Zabacheras-Galve area, a Kimmeridgian-Early Berriasian? age. This age contrasts with that assigned by previous authors, who commonly have considered these deposits as ranging from the Kimmeridgian to the Early Cretaceous (Berriasian, Valanginian, Hauterivian, Barremian and even, locally, Aptian-Albian, depending on the area).

2. These findings have important consequences regarding the age of the dinosaur fossils found in these deposits, which may have been erroneously assigned to the Jurassic-Cretaceous transition, or even to the Early Cretaceous.
3. The studied dinosaur-bearing sedimentary record in all the studied areas, of both the western Maestrazgo and South-Iberian basins, is very similar in facies, facies distribution and evolution, and fossil content: it comprises a carbonate-dominated CLP, which was deposited in an inner shallow carbonate platform-lagoon connected with a coastal and alluvial plain, and a SUP, essentially siliciclastic, deposited in a coastal wetland system, comprising vegetated, coastal alluvial plains, fluvial channels, overbank and deltaic deposits, and locally aeolian dunes, which were laterally connected with limestone deposited in an inner shallow to very shallow marine platformlagoon. The main differences observed in the studied sedimentary record at the different areas are that in sections located towards the E-SE, relatively close to the Tethys Sea during deposition, the sedimentary record is thicker and has more limestone beds containing fully marine biota than sections located towards the $\mathrm{W}$ and $\mathrm{N}$.

The general sedimentary evolution is regressive, although a transgressive episode occurring in the Tithonian, has been recorded in the areas located to the ESE, both in the western Maestrazgo and South-Iberian basins.

4. Data provided in this work have necessitated a substantial revision of the limits, ages and correlations of the lithostratigraphic units comprising the studied sedimentary record. The DSR in all the areas is correlatable in facies, fossil content, sedimentary evolution and age with deposits of the Villar del Arzobispo Fm in the western Maestrazgo Basin, and specifically in the Cedrillas area, where the parastratotype of the unit was defined and where this unit crops out exceptionally well and is properly dated from the base to the top:

(a) Carbonate-dominated deposits of the CLP of the DSR in the South-Iberian Basin, originally assigned to the Villar del Arzobispo Fm, are correlatable in facies and age (Kimmeridgian) only with those of the carbonate-dominated CLP of the Villar del Arzobispo Fm in the Cedrillas area.

(b) Deposits previously assigned to the Lower Cretaceous Aldea de Cortés and El Collado Fms in the South-Iberian Basin are correlatable in facies and age (Tithonian) with siliciclastic-dominated deposits of the SUP of the Villar del Arzobispo Fm in the Cedrillas area.

(c) Thus, the usage of the Aldea de Cortés and El Collado Fms should be avoided, and the limits, age, and stratotype of the Villar del Arzobispo Fm, as formaly defined by Mas et al. (1984), should be revisited. We consider that, the parastratotype of the Villar del Arzobispo Fm, located in the Cedril- 
las area, in the western Maestrazgo Basin, would be an excellent candidate for redefining the unit.

5. The studied dinosaur-bearing sedimentary record should be correlated with other Kimmeridgian-Tithonian dinosaur-bearing deposits of Iberia, such as those of the Cameros, Asturias and Lusitanian basins. In fact, ages obtained from larger benthic foraminifera agree with data provided by the systematics of dinosaurs, since dinosaur faunas of Eastern Spain are similar to those of the Late Jurassic of other areas of Iberia, especially with those of the Lusitanian Basin (Portugal).

Acknowledgements This research was funded by the Spanish projects CGL2014-52670-P, CGL2013-41295-P DINOTUR and CGL201569805-P of the Ministry of Economy and Competitiveness, by the "Sedimentary Basin Analysis" UCM Research Group (Ref. 910429), by the Department of Education, Culture and Sport and the Department of Innovation, Research and University of the Government of Aragón, by the FEDER Aragón 2014-2020 "Construyendo Europa desde Aragón" (FOCONTUR Quality Research Group E04_17R) and by the Instituto Aragonés de Fomento. The authors also thank the UCM Reseach Group "Sedimentary Geology, Paleoclimate and Environmental Change (Ref. 910198). Sonia Campos-Soto is supported by a FPU predoctoral fellowship of the Spanish Ministry of Education (Ref. FPU13/02978). We thank to reviewers Martin G. Lockley and Matías Reolid and to the editor for their suggestions, which have improved the paper. We are thankful to Beatriz Moral, Juan Carlos Salamanca and Aitor Antón for thin-section preparation and laboratory support, to Laura Donadeo for helping with bibliography and to Valle López for helping with ArcGIS

\section{References}

Alcalá, L., Cobos, A., Delclòs, X., Luque, L., Mampel, L., Royo-Torres, R., et al. (2009). Mesozoic terrestrial ecosystems in Teruel. In L. Alcalá, R. Royo-Torres (Coord.), Mesozoic Terrestrial ecosystems in Eastern Spain ;Fundamental! (pp. 93-130). Teruel: Fundación Conjunto Paleontológico de Teruel-Dinópolis.

Alcalá, L., Cobos, A., Espílez, E., Gascó, F., Mampel, L., MartínEscorza, C., et al. (2012). Icnitas de dinosaurios en la Formación Villar del Arzobispo de Ababuj (Teruel, España). Geogaceta, $51,35-38$.

Alcalá, L., Cobos, A., \& Royo-Torres, R. (2018). Dinosaurios de la Península Ibérica. PH: Boletín del Instituto Andaluz del Patrimonio Histórico, 26(94), 116-153.

Alcalá, L., Mampel, L., Royo-Torres, R., \& Cobos, A. (2014a). On small quadrupedal ornithopod tracks in Jurassic-Cretaceous transition intertidal deposits (El Castellar, Teruel, Spain). Spanish Journal of Palaeontology, 29(2), 183-190.

Alcalá, L., Pérez-Lorente, F., Luque, L., Cobos, A., Royo-Torres, R., \& Mampel, L. (2014b). Preservation of Dinosaur footprints in shallowing intertidal deposits of the Jurassic-Cretaceous transition in the Iberian Range (Teruel, Spain). Ichnos, 21(1), 19-31.

Alves, T. M., Gawthorpe, R. L., Hunt, D. W., \& Monteiro, J. H. (2002). Jurassic tectono-sedimentary evolution of the Northern Lusitanian Basin (offshore Portugal). Marine and Petroleum Geology, 19(6), 727-754.
Antunes, M. T., \& Mateus, O. (2003). Dinosaurs of Portugal. Comptes Rendus Palevol, 2(1), 77-95.

Arias, C. (1978). Estratigrafia y paleogeografia del Jurásico superior y 3681 Cretácico inferior del nordeste de la provincia de Albacete. Serie Monografías 3 (p. 299). Madrid: Universidad Complutense de Madrid.

Assens, J., Ramírez del Pozo, J., Giannini, G., Riba, O., Vilena, J., \& Reguant, S. (1973). Memoria de la Hoja n 666 (Chelva), Mapa Geológico de España E. 1:50.000 (MAGNA). Segunda serie, Primera edición. Madrid: I.G.M.E.

Aurell, M. (1990). El Jurásico superior de la Cordillera Ibérica Central (provincias de Zaragoza y Teruel). Análisis de Cuenca. Tesis Doctoral (p. 510). Zaragoza: Universidad de Zaragoza.

Aurell, M., Bádenas, B., Gascá, J. M., Canudo, J. I., Liesa, C. L., Soria, A. R., et al. (2016). Stratigraphy and evolution of the Galve subbasin (Spain) in the middle Tithonian-early Barremian: Implications for the setting and age of some dinosaur fossil sites. Cretaceous Research, 65, 138-162.

Aurell, M., Mas, R., Meléndez, A., \& Salas, R. (1994). El tránsito Jurásico-Cretácico en la Cordillera Ibérica: Relación tectónicasedimentación y evolución paleogeográfica. Cuadernos de Geología Ibérica, 18, 369-396.

Aurell, M., \& Meléndez, A. (1993). Sedimentary evolution and sequence stratigraphy of the Upper Jurassic in the Central Iberian Chain, northeast Spain. Special Publications International Association of Sedimentologists, 18, 343-368.

Aurell, M., Robles, S., Bádenas, B., Rosales, I., Quesada, S., Meléndez, G., et al. (2003). Transgressive-regressive cycles and Jurassic palaeogeography of northeast Iberia. Sedimentary Geology, 162(3-4), 239-271.

Avanzini, M., Piñuela, L., \& García-Ramos, J. C. (2012). Late Jurassic footprints reveal walking kinematics of theropod dinosaurs. Lethaia, 45(2), 238-252.

Aznar, J. M., Olivé, A., Moissenet, E., Hernández, A., Portero, J. M., Gutiérrez, M., et al. (1983). Memoria de la Hoja ${ }^{\circ} 589$ (Terriente), Mapa Geológico de España E. 1:50.000 (MAGNA). Segunda serie. Madrid: I.G.M.E.

Bádenas, B., \& Aurell, M. (2010). Facies models of a shallow-water carbonate ramp based on distribution of non-skeletal grains (Kimmeridgian, Spain). Facies, 56, 89-110.

Bádenas, B., Aurell, M., \& Gasca, J. M. (2018). Facies model of a mixed clastic-carbonate, wave-dominated open-coast tidal flat (Tithonian-Berriasian, north-east Spain). Sedimentology, 65(5), 1631-1666.

Bádenas, B., Aurell, M., Ipas, J., \& Espílez, E. (2008-2009). Evolución de facies y secuencias de alta frecuencia en las plataformas del final del Jurásico al suroeste de la provincia de Teruel. Teruel, 92, 69-96.

Bádenas, B., Salas, R., \& Aurell, M. (2004). Three orders of regional sea-level changes control facies and stacking patterns of shallow carbonates in the Maestrat Basin (Tithonian-Berriasian, NE Spain). International Journal of Earth Sciences, 93(1), 144-162.

Barco, J. L. (2009). Sistemática e implicaciones filogenéticas y paleobiogeográficas del saurópodo Galvesaurus herreroi (Formación Villar del Arzobispo, Galve, España). Tesis Doctoral (p. 389). Zaragoza: Universidad de Zaragoza.

Bassoullet, J.-P. (1997). Les grands foraminifères. In E. Cariou \& P Hantzperque (Eds.), Biostratigraphie du Jurassique ouest-européen et méditerranéen (17 (pp. 293-304). Pau: Centre Recherche Elf Exploration-Production. (Mem.).

Benito, M. I., Lohmann, K. C., \& Mas, R. (2001). Discrimination of multiple episodes of meteoric diagenesis in a Kimmeridgian reefal complex, North Iberian Range, Spain. Journal of Sedimentary Research, 71(3), 380-393.

Benito, M. I., Lohmann, K. C., \& Mas, R. (2005). Late Jurassic palaeogeography and palaeoclimate in the Northern Iberian Basin 
of Spain: Constraints from diagenetic records in reefal and continental carbonates. Journal of Sedimentary Research, 75(1), 82-96.

Benito, M. I., \& Mas, R. (2002). Evolución diagenética de los carbonatos arrecifales de la Formación Torrecilla en Cameros (Kimmeridgiense inferior) y de los carbonatos de la base de la Aloformación Ágreda (Titónico) en el Sector de Soria. Cuenca de Cameros. N. España. Journal of Iberian Geology, 28, 65-92.

Benito, M. I., \& Mas, R. (2006). Sedimentary evolution of the Early Kimmeridgian Torrecilla Reef Complex in response to tectonically forced regression. Northern Spain. Sedimentary Geology, 183(1-2), 31-49.

Benke, K., Dürkoop, A., Errenst, C., \& Mensik, H. (1981). Die Korallenkalke im Ober-Jura der nordwestlichen Iberischen Ketten (Spanien). Facies, 4(1), 27-94.

Bhattacharya, J. P. (2010). Deltas. In N. P. James \& R. W. Dalrymple (Eds.), Facies Models 4 (pp. 233-264). Toronto: Geological Association of Canada.

Bonaparte, J. F., \& Mateus, O. (1999). A new diplodocid, Dinheirosaurus lourinhanensis gen et sp nov, from the Late Jurassic beds of Portugal. Revista del Museo Argentino de Ciencias Naturales, 5(2), 13-29.

Campos-Soto, S., Benito, M. I., Mas, R., Caus, E., Cobos, A., SuarezGonzalez, P., et al. (2016a). Revisiting the Late Jurassic-Early Cretaceous of the NW South Iberian Basin: new ages and sedimentary environments. Journal of Iberian Geology, 42(1), 69-94.

Campos-Soto, S., Benito, M. I., Mas, R., Quijada, I. E., \& SuarezGonzalez, P. (2015). Between tides, winds and rivers: deciphering challenging sandstone bodies in a multifaceted coastal system (Late Jurassic-Early Cretaceous, South Iberian Basin, SE Spain). In 9th International Conference on Tidal Sedimentology, Abstracts (pp. 46-49)

Campos-Soto, S., Benito, M. I., Mountney, N. P., Quijada, I. E., SuarezGonzalez, P., Cobos, A., et al. (2017b). Unveiling coastal aeolian facies in the Upper Jurassic record of eastern Iberia: new insights from the dinosaur fossil-bearing Villar del Arzobispo Fm (Teruel, E Spain). In 33rd International Meeting of Sedimentology, Abstracts (p. 151).

Campos-Soto, S., Caus, E., Bucur, I. I., Bentio, M. I., Suarez-Gonzalez, P., Quijada, I. E., et al. (2016b). Registro de una transgresión marina en torno al tránsito Jurásico-Cretácico al oeste de la subcuenca de Peñagolosa (Teruel). Geo-Temas, 16(1), 121-124.

Campos-Soto, S., Cobos, A., Caus, E., Benito, M. I., Fernández-Labrador, L., Suarez-Gonzalez, P., et al. (2017a). Jurassic Coastal Park: a great diversity of palaeoenvironments for the dinosaurs of the Villar del Arzobispo Formation (Teruel, eastern Spain). Palaeogeography, Palaeoclimatology, Palaeoecology, 485(1), 154-177.

Canérot, J. (1974). Reserches geologiques aux confins des chaines iberique et catalane (Espagne). Tesis Doctoral (p. 517). Toulouse: Laboratoire de géologie de l'Université Paul Sabatier.

Canérot, J., Cugny, P., Pardo, G., Salas, R., \& Villena, J. (1982). Ibérica Central-Maestrazgo. In A. García (Ed.), El Cretácico de España (pp. 273-344). Madrid: Universidad Complutense de Madrid.

Canudo, J. I., Barco, J. L., Castanera, D., \& Torcida Fernández-Baldor, F. (2010). New record of a sauropod in the Jurassic-Cretaceous transition of the Iberian Peninsular (Spain): palaeobiogeographical implications. Paläontologische Zeitschrift, 84(3), 427-435.

Canudo, J. I., Gasca, J. M., Moreno-Azanza, M., \& Aurell, M. (2012). New information about the stratigraphic position and age of the sauropod Aragosaurus ischiaticus from the Early Cretaceous of the Iberian Peninsula. Geological Magazine, 149(2), 252-263.

Casanovas-Cladellas, M. L., Santafé-LLopis, J. V., Santisteban, C., \& Pereda-Suberbiola, X. (1999). Estegosaurios (Dinosauria) del Jurásico Superior-Cretácico Inferior de la Comarca de los
Serranos (Valencia, España). Revista Española de Paleontología, $n^{o}$ extr. Homenaje al Prof. J. Truyols, 57-63.

Casanovas-Cladellas, M. L., Santafé-Llopis, J. V., \& Sanz, J. L. (2001). Losillasaurus giganteus, un nuevo saurópodo del tránsito Jurásico-Cretácico de la cuenca de "Los Serranos" (Valencia, España). Paleontologia i Evolució, 32-33, 99-122.

Castanera, D., Barco, J. L., Díaz-Martínez, I., Herrero-Gascón, J., Pérez-Lorente, F., \& Canudo, J. I. (2011). New evidence of a herd of titanosauriform sauropods from the Lower Berriasian of the Iberian range (Spain). Palaeogeography, Palaeoclimatology, Palaeoecology, 310(3-4), 227-237.

Castanera, D., Bila, B., Razzolini, N. L., Falkingham, P. L., Canudo, J. I., Manning, P. L., et al. (2013). Manus track preservation bias as a key factor for assessing trackmaker identity and quadrupedalism in basal ornithopods. PLoS One, 8(9), e54177.

Castanera, D., Pascual, C., Canudo, J. I., Hernández, N., \& Barco, J. L. (2012). Ethological variations in gauge in sauropod trackways from the Berriasian of Spain. Lethaia, 45(4), 476-489.

Castanera, D., Santos, V. F., Piñuela, L., Pascual, C., Vila, B., Canudo, J. I., et al. (2016). Iberian Sauropod Tracks through Time: Variations in Sauropod Manus and Pes Track Morphologies. In P. L. Falkingham, D. Marty, \& A. Richter (Eds.), Dinosaur Tracks, The next steps (pp. 120-137). Bloomington: Indiana University Press.

Castanera, D., Vila, B., Razzolini, N. L., Santos, V. F., Pascual, C., \& Canudo, J. L. (2014). Sauropod trackways of the Iberian Peninsula: palaeoetological and palaeoenvironmental implications. Journal of Iberian Geology, 40(1), 49-59.

Cobos, A., Alcalá, L., \& Mampel, L. (2012b). Stegosaurian footprints from the Jurassic-Cretaceous transition in Teruel (Spain). In The 11th Symposium on Mesozoic Terrestrial Ecosystems, Abstracts (pp 407-409).

Cobos, A., Alcalá, L., Rodríguez-Tovar, F. J., \& Mampel, L. (2017). Ichnological Analysis of a Good of Cultural Interest: the Site of El Hoyo (El Castellar, Aragón, Spain). Geoheritage, 10(3), $415-425$.

Cobos, A., \& Gascó, F. (2013). New vertebral remains of the stegosaurian dinosaur Dacentrurus from Riodeva (Teruel, Spain). Geogaceta, 53, 17-20.

Cobos, A., Lockley, M. G., Gascó, F., Royo-Torres, R., \& Alcalá, L. (2014). Megatheropods as apex predators in the typically Jurassic ecosystems of the Villar del Arzobispo Formation (Iberian Range, Spain). Palaeogeography, Palaeoclimatology, Palaeoecology, 399, 31-41.

Cobos, A., Mampel, L., Royo-Torres, R., Espílez, E., \& Alcalá, L. (2005). Nuevos yacimientos de icnitas de dinosaurio en Formiche Alto (Teruel). Geogaceta, 38, 19-22.

Cobos, A., Royo-Torres, R., \& Alcalá, L. (2012a). Restos postcraneales de ornitópodo en el Cretácico Inferior de El Castellar (Subcuenca de Peñagolosa, Teruel). Geogaceta, 52, 181-184.

Cobos, A., Royo-Torres, R., Gascó, F. \& Alcalá, L. (2011). A new giant turiasaurian specimen from Riodeva (Teruel, Spain). In 9th Annual Meeting European Association of Vertebrate Palaeontologists, Abstracts (p. 18).

Cobos, A., Royo-Torres, R., Luque, L., Alcala, L., \& Mampel, L. (2010). An Iberian stegosaurs paradise: the Villar del Arzobispo Formation (Tithonian-Berriasian) in Teruel (Spain). Palaeogeography, Palaeoclimatology, Palaeoecology, 293(1-2), 223-236.

Cobos, A., Royo-Torres, R., Torrente, M. A., \& Alcalá, L. (2015). Nuevos fósiles de dinosaurios en la Formación Villar del Arzobispo de El Castellar y Formiche Alto (Teruel, España). Geogaceta, 58, 47-50.

Collinson, J. D. (1996). Alluvial sediments. In H. G. Reading (Ed.), Sedimentary Environments: Processes, Facies and Stratigraphy (3rd ed., pp. 37-82). Oxford: Blackwell Science. 
Company, J., Pereda-Suberbiola, X., \& Ruiz-Omeñaca, J. I. (2010). New stegosaurian (Ornithischia, Thyreophora) remains from Jurassic-Cretaceous transition beds of Valencia province (Southwestern Iberian Range, Spain). Journal of Iberian Geology, 36(2), 243-252.

Conze, R., Errenst, C., \& Mensink, H. (1984). Die Ammoniten des Ober-Callovium bis Unter-Kimmeridgium in den Nordwestlichen Keltiberischen Ketten. Palaeontographica Abteilung A, 183, 162-211.

Cuenca-Bescós, G., Canudo, J. I., \& Ruiz-Omeñaca, J. I. (1997). Dinosaurios del tránsito Jurásico-Cretácico en Aragón. In J. A. Gámez-Vintaned \& E. V. Liñan (Eds.), Jornadas Aragonesas de Paleontología "Vida y ambientes del Jurásico" (pp. 193-221). Zaragoza: Institución Fernando el Católico.

Dantas, P., Sanz, J. L., Silva, C. M., Ortega, F., Santos, V. F., \& Cachão, M. (1998). Lourinhasaurus n. gen. novo dinossáurio saurópode do Jurássico superior (Kimmeridgiano superior Titoniano inferior) de Portugal. In Actas do V Congresso de Geologia 84, Abstracts (pp. 91-94).

de la Moussaye, G. (1885). Sur une dent de Neosodon trouve'e dans les sables ferrugineux de Wimille. Bulletin de la Société Géologique de France, 44, 51-54.

Delvene, G., Lozano, P., Munt, M., Royo-Torres, R., Cobos, A., \& Alcalá, L. (2019). Bivalves and oncoids as palaeoenvironmental indicators at Late Jurassic and Early Cretaceous dinosaur sites from Spain. Proceedings of the Geologists' Association, 130, 87-102.

Díaz-Molina, M., \& Yébenes, A. (1987). La sedimentación litoral y continental durante el Cretácico inferior Sinclinal de Galve, Teruel. Estudios Geológicos, 43, 3-21. (Extra).

Díaz-Molina, M., Yébenes, A., \& Goy, A. (1984). Landscapes inhabited by Upper Jurassic/Lower Cretaceous archosaurs (Galve, Teruel). In W. E. Reif \& F. Westphal (Eds.), Third Symposium on Mesozoic Terrestial Ecosystems (pp. 67-72). Tübingen: Attempto Verlag.

Díaz-Molina, M., Yébenes, A., \& Goy, A. (1985). Le Jurassique Superieur detritique-carbonate du sinclinal del Galve (Teruel). Strata, 2(2), 155-182.

Dunham, R. J. (1962). Classification of carbonate rocks according to depositional texture. In W. E. Ham (Ed.), Classification of carbonate rocks (pp. 108-121). Tulsa: AAPG. Mem. 1.

Einsele, G. (2000). Sedimentary basins: Evolution, facies and sediment budget (p. 727). Berlin: Springer.

Errenst, C. (1990). Das korallenführende Kimmeridgium der nordwestlichen Iberischen Ketten und angrenzender gebiete (Fazies, paläogeographie und beschreibung der korallenfauna). Teil 1. Palaeontographica Abteilung A, 214, 121-207.

Errenst, C. (1991). Das korallenführende Kimmeridgium der nordwestlichen Iberischen Ketten und angrenzender gebiete (Fazies, paläogeographie und beschreibung der korallenfauna). Teil 2. Palaeontographica Abteilung A, 215, 1-42.

Escaso, F. (2014). Historia evolutiva de los Ornithischia (Dinosauria) del Jurásico Superior de Portugal. Tesis Doctoral (p. 289). Madrid: Universidad Autónoma de Madrid. Unpublished.

Escaso, F., Ortega, F., Dantas, P., Malafaia, E., Pimentel, N. L., PeredaSuberbiola, X., et al. (2007). New evidence of shared dinosaur across Upper Jurassic Proto-North Atlantic: Stegosaurus from Portugal. Naturwissenschaften, 94(5), 367-374.

Felgueroso, C., \& Ramírez del Pozo, J. (1971). Estratigrafía del Jurásico en la zona de Teurel-Morella (Maestrazgo). Cuadernos de Geología Ibérica, 2, 439-488.

Fezer, R. (1988). Die oberjurassische karbonatische Regressionsfazies im südwestlichen Keltiberikum zwischen Griegos und Aras de Alpuente (Prov. Teruel, Cuenca, Valencia; Spanien). Arbeiten aus dem Institut für Geologie und Paläontologie, 84, 1-119.
Fürsich, F. T., Werner, W., Delvene, G., García-Ramos, J. C., Bermúdez-Rochas, D., \& Piñuela, L. (2012). Taphonomy and palaeoecology of high-stress benthic associations from the Upper Jurassic of Asturias, northern Spain. Palaeogeography, Palaeoclimatology, Palaeoecology, 358-360, 1-18.

García-Ramos, J. C., Aramburu, C., Piñuela, L., \& Lires, J. (2000). La costa de los dinosaurios. Rutas por el Jurásico de Asturias (p. 33). Principado de Asturias: Consejería de Educación y Cultura.

García-Ramos, J. C., \& Gutiérrez-Claverol, M. (1995). La Geología de la Franja Costera Oriental y la Depresión Prelitoral de OviedoCangas de Onís. In C. Aramburu \& F. Bastida (Eds.), Geología de Asturias (pp. 247-258). Gijón: Trea SL.

García-Ramos, J. C., Lires, J., \& Piñuela, L. (2002). Dinosaurios. Rutas por el Jurásico de Asturias (p. 204). Siero: La Voz de Asturias.

García-Ramos, J. C., Piñuela, L., \& Lires, J. (2004). Guía del Jurásico de Asturias. Rutas por los yacimientos de huellas de dinosaurios (p. 118). Gijón: Zinco Comunicación.

García-Ramos, J. C., Piñuela, L., \& Ruiz-Omeñaca, J. I. (2006). Vertebrate tracks from the Late Jurassic (Kimmeridgian) of Asturias (north Spain). Journal of Vertebrate Paleontology, 26(3), 65A.

García-Ramos, J. C., \& Valenzuela, M. (1977a). Hallazgo de huellas de pisada de Vertebrados en el Jurásico de la costa asturiana entre Gijón y Ribadesella. Breviora Geológica Astúrica, 21, 17-21.

García-Ramos, J. C., \& Valenzuela, M. (1977b). Huellas de pisadas de Vertebrados (Dinosaurios y otros) en el Jurásico Superior de Asturias. Estudios Geológicos, 10, 13-22.

Gascó, F., Cobos, A., Royo-Torres, R., Mampel, L., \& Alcalá, L. (2012). Theropod teeth diversity from the Villar del Arzobispo Formation (Tithonian-Berriasian) at Riodeva (Teruel, Spain). Palaeobiodiversity and Palaeoenvironments, 92(2), 273-285.

Gascó, F., Verdú, J., Cobos, A., Royo-Torres, R., \& Alcalá, L. (2013). Los ornitópodos de Barrihonda-El Humero en la Formación Villar del Arzobispo de Riodeva (Teruel, España). In XXIX Jornadas de la Sociedad Española de Paleontología, Abstracts (pp. 149-150)

Gautier, F. (1968). Sur la stratigraphie et les facies du Jurassique supériur et du Crétacé inférieur au Nord de Teruel (Espagne). Compte Rendu Sommaire des Séances de la Société Géologique de France, 2, 43-44.

Gautier, F., \& Viallard, P. (1966). Sur le Jurassique terminal et le Crátacé du Nord de la province de Valence (Espagne). Comptes Rendus Hebdomadaires des Seances de l'academie des Sciences Serie D, 262, 432-435.

Godoy, A., Anadón, P., Berastegui, J., Ramírez, J. I., Olivé, A., Aguilar, M. J., et al. (1986). Memoria de la Hoja $n^{\circ} 591$ (Mora de Rubielos), Mapa geológico de España E. 1:50.000 (MAGNA). Segunda serie, Primera edición. Madrid: I.G.M.E.

Godoy, A., Olivé, A., Moissenet, E., Gutiérrez, M., Aguilar, M. J., Ramírez, J., et al. (1983a). Memoria de la Hoja no 567 (Teruel), Mapa Geológico de España E. 1:50.000. Segunda serie (MAGNA), Primera edición. Madrid: I.G.M.E.

Godoy, A., Olivé, A., Moissenet, E., Gutiérrez, M., Aguilar, M. J., Ramírez, J., et al. (1983b). Memoria de la Hoja no 590 (La Puebla de Valverde), Mapa Geológico de España E. 1:50.000. Segunda serie (MAGNA), Primera edición. Madrid: I.G.M.E.

Gómez, J. C. (1979). El Jurásico en facies carbonatadas del Sector Levantino de la Cordillera Ibérica. Seminarios de Estratigrafía, Serie Monografías 4 (p. 683). Madrid: Universidad Complutense de Madrid.

Gómez-Fernández, J. C., \& Meléndez, N. (1994). Estratigrafía de la "Cuenca de los Cameros" (Cordillera Ibérica Noroccidental, N de España) durante el tránsito Jurásico-Cretácico. Revista de la Sociedad Geológica de España, 7(1-2), 121-139.

González Lodeiro, F., Ponce, Iglesias, de León, M., Rubio Novas, J., García Salinas, F., Abril Hurtado, J., et al. (1975). Memoria de la 
Hoja $n^{o} 638$ (Alpuente), Mapa Geológico de España E. 1:50.000 (MAGNA). Segunda serie, Primera edición. Madrid: I.G.M.E.

González-Fernández, B., Menéndez-Casares, E., Vicedo, V., Aramburu, C., \& Caus, E. (2014). New insights about the Upper Jurassic-Lower Cretaceous sedimentary successions from Asturias (NW Iberian Peninsula). Journal of Iberian Geology, 40(3), 409-430.

Gradstein, F. G., Ogg, J. G., Schmitz, M. D., \& Ogg, G. M. (2012). The Geologic Time Scale (p. 1176). Boston: Elsevier.

Hernández, A., Godoy, A., Álvaro, M., Ramírez, J. I., Leal, M. C., Aguilar, M., et al. (1985). Memoria de la Hoja $n^{\circ} 47$ (Teruel), Mapa geológico de España E. 1:20.0000 (MAGNA). Primera edición. Madrid: I.G.M.E.

Hernández-Medrano, N., Pascual-Arribas, C., \& Pérez-Lorente, F. (2017). First pterosaur footprints from the Tera Group (Tithonian-Berriasian) Cameros Basin, Spain. Journal of Iberian Geology, 43(2), 245-255.

Herrero-Gascón, J., \& Pérez-Lorente, F. (2017). Hoof-Like Unguals, Skin, and Foot Movements Deduced from Deltapodus Casts of the Galve Basin (Upper Jurassic-Lower Cretaceous, Teruel, Spain). Ichnos, 24(2), 146-161.

Hill, G. (1989). Distal alluvial fan sediments from the Upper Jurassic of Portugal: controls on their cyclicity and channel formation. Journal of the Geological Society, 146(3), 539-555.

Hottinger, L. (1967). Foraminiferes imperforés du Mésozoique marocain, Notes et Mémoires du Service Géologique du Maroc 209 (p. 168). Rabat: Editions du Service Geologique du Maroc.

Kullberg, J. C., Rocha, R. B., Soares, A. F., Rey, J., Terrinha, P., Azerêdo, A. C., et al. (2013). A Bacia Lusitaniana: Estratigrafia, Paleogeografia e Tectónica. In R. Dias, A. Araújo, P. Terrinha, \& J. C. Kullberg (Eds.), Geología de Portugal, Volume II-Geología Meso-cenozóica de Portugal (pp. 195-350). Lisboa: Escolar Editora.

Lazuen, J., Roldán, R., Goy, A., García, A., \& Quintero, I. (1977). Memoria de la Hoja $n^{o} 667$ (Villar del Arzobispo), Mapa geológico de España E. 1:50.000 (MAGNA), Segunda serie. Primera edición. Madrid: I.G.M.E.

Legler, B., Johnson, H. D., Hampson, G. J., Massart, B. Y. G., Jackson, C. A. L., Jackson, M. D., et al. (2013). Facies model of a fine-grained, tide-dominated delta: Lower Dir Abu Lifa Member (Eocene), Western Desert, Egypt. Sedimentology, 60(5), 1313-1356.

Leinfelder, R. R. (1993). A sequence stratigraphic approach to the Upper Jurassic mixed carbonate-siliciclastic succession of the central Lusitanian Basin, Portugal. Profil, 5, 119-140.

Leinfelder, R. R., \& Wilson, R. C. (1989). Seismic and sedimentologic features of Oxfordian-Kimmeridgian syn-rift sediments on the eastern margin of the Lusitanian Basin. Geologische Rundschau, 78(1), 81-104.

Leinfelder, R. R., \& Wilson, R. C. (1998). Third-order sequences in an Upper Jurassic rift-related second-order sequence, Central Lusitanian Basin, Portugal. In P.-C. de Graciansky, J. Hardenbol, P. Jacquin, \& P. Vail (Eds.), Mesozoic and Cenozoic Sequence Stratigraphy of European Basins, SEPM Special Publication 60 (pp. 507-525). Tulsa: SEPM.

Lockley, M. G., García-Ramos, J. C., Piñuela, L., \& Avanzini, M. (2008). A review of vertebrate track assemblages from the Late Jurassic of Asturias, Spain with comparative notes on coeval ichnofaunas from the western USA: implications for faunal diversity in association with siliciclastic facies assemblages. Oryctos, 8 , 53-70.

Loeblich, A. R., \& Tappan, H. (1988). Foraminiferal Genera and Their Classification (p. 970). New York: Van Nostrand Reinhold Company.

López Olmedo, F., Palacio Suárez, J. P., Dávila Ruiz, M. D. T., Luís López, F., García Rojo, E., Martínez Cano, M., et al. (2018).
Mapa Geológico Digital continuo E. 1:50.000, Zona Ibérica (Zona-1700). GEODE. Mapa Geológico Digital Continuo de España, http://info.igme.es/cartografiadigital/geologica/geode zona.aspx?Id=Z1700. Accessed 1 Sept 2018.

Luque, L., Cobos, A., Royo-Torres, R., Espílez, E., \& Alcalá, L. (2005). Caracterización de los depósitos sedimentarios con dinosaurios de Riodeva (Teruel). Geogaceta, 38, 27-30.

Suñer, M. Santisteban, C., \& Royo-Torres, R. (2014). Nuevas evidencias de dinosaurios saurópodos en el tránsito Jurásico-Cretácico de Alpuente (Los Serranos, Valencia). ¡Fundamental!, 24, 233-236.

Maidment, S. C. R., Norman, D. B., Barret, P. M., \& Upchurch, P. (2008). Systematics and phylogeny of Stegosauria (Dinosauria: Ornithischia). Journal of Systematic Palaeontology, 6(4), 367-407.

Malafaia, E., Mocho, P., Escaso, F., \& Ortega, F. (2017). New data on the anatomy of Torvosaurus and other remains of megalosauroid (Dinosauria, Theropoda) from the Upper Jurassic of Portugal. Journal of Iberian Geology, 43(1), 33-59.

Mampel, L., Cobos, A., Alcalá, L., Espílez, E., Royo-Torres, R., González, A., et al. (2010-2011). Icnitas de dinosaurios en Aguilar del Alfambra (Teruel, España). Teruel, 93, 41-54.

Martín-Chivelet, J., Berástegui, X., Rosales, I., Vilas, L., Vera, J. A., Caus, E., et al. (2002). Cretaceous. In W. Gibbons \& T. Moreno (Eds.), The Geology of Spain (pp. 255-292). London: The Geological Society.

Martín-Closas, C. (1989). Els carofits del Cretaci inferior de les conques periferiques del Bloc de l'Ebre. Tesis Doctoral (p. 581). Barcelona: Universidad de Barcelona. (Unpublished).

Martín-Closas, C., \& Alonso-Millán, A. (1998). Estratigrafía y bioestratigrafía (Charophyta) del Cretácico inferior en el sector occidental de la Cuenca de Cameros (Cordillera Ibérica). Revista de la Sociedad Geológica de España, 11(3-4), 253-269.

Martinius, A. W., \& Gowland, S. (2011). Tide-influenced fluvial bedforms and tidal bore deposits (Late Jurassic Lourinhã Formation, Lusitanian Basin, Western Portugal). Sedimentology, 58(1), 285-324.

Mas, R. (1981). El Cretácico inferior de la región Noroccidental de la provincia de Valencia. Seminarios de Estratigrafía, Serie Monografías 8 (p. 408). Madrid: Universidad Complutense de Madrid.

Mas, R., \& Alonso, A. (1981). Trabajo estratigráfico, sedimentológico y paleogeográfico de las facies Purbeck, Weald y Utrillas en el sector suroriental de la Cordillera Ibérica. Memorias de las Hojas $n^{\circ} 55$ (Lliria) y 43 (Valencia), Mapa Geológico de España E. 1:200.000 (MAGNA). Segunda serie. Madrid: I.G.M.E. (Unpublished).

Mas, R., Alonso, A., \& Meléndez, N. (1984). La formación Villar del Arzobispo: un ejemplo de llanuras de mareas siliciclásticas asociadas a plataformas carbonatadas. Jurasico terminal. (NW de Valencia y E de Cuenca). Publicaciones de Geología, 20, $175-188$

Mas, R., Arribas, M. E., González-Acebrón, L., Quijada, I. E., CamposSoto, S., Suarez-Gonzalez, P., et al. (2019). Coastal wetlands as markers of transgression in proximal extensional systems (Berriasian, W Cameros Basin, Spain). Journal of Iberian Geology, 45(1), 1-27.

Mas, R., Benito, M. I., Arribas, J., Alonso, A., Arribas, M. E., Lohmann, K. C., et al. (2011). Evolution of an intra-plate rift basin: the Latest Jurassic-Early Cretaceous Cameros Basin (Northwest Iberian Ranges, North Spain). In C. Arenas, L. Pomar, \& F. Colombo (Eds.), Post-Meeting Field trips 28th IAS Meeting, Zaragoza, Geo-guías 8 (pp. 117-154). Zaragoza: SGE.

Mas, R., García, A., Salas, R., Meléndez, A., Alonso, A., Aurell, M., et al. (2004). Segunda fase de rifting: Jurásico Superior-Cretácico Inferior. In J. A. Vera (Ed.), Geología de España (pp. 503-510). Madrid: SGE-IGME. 
Mateus, O., Mannion, P. D., \& Upchurch, P. (2014). Zby atlanticus, a new turiasaurian sauropod Dinosauria, Eusauropoda) from the Late Jurassic of Portugal. Journal of Vertebrate Paleontology, 34(3), 618-634.

Mckee, E. D. (1966). Structures of dunes at White Sands National Monument, New Mexico (and a comparison with structures of dunes from other selected areas). Sedimentology, 7(1), 3-69.

Miall, A. D. (1996). The Geology of Fluvial Deposits (p. 582). Berlin: Springer.

Miall, A. D. (1997). The Geology of Stratigraphic Sequences (1st ed., p. 433). Berlin: Springer- Verlag.

Miall, A. D. (2010). The Geology of Stratigraphic Sequences (2nd ed., p. 465). Berlin: Springer.

Mocho, P., Royo-Torres, R., Escaso, F., Malafaia, E., de Miguel Chaves, C., Narváez, I., et al. (2017a). Upper Jurassic sauropod record in the Lusitanian Basin (Portugal) Geographical and lithostratigraphical distribution. Palaeontologia Electronica, 20.2.27A, 1-50.

Mocho, P., Royo-Torres, R., \& Ortega, F. (2014). Phylogenetic reassessment of Lourinhasaurus alenquerensis, a basal Macronaria (Sauropoda) from the Upper Jurassic of Portugal. Zoological Journal of the Linnean Society, 170(4), 875-916.

Mocho, P., Royo-Torres, R., \& Ortega, F. (2017b). New data for the Portuguese brachiosaurid Lusotitan atalaiensis (Sobral Formation, Upper Jurassic). Historical Biology, 29(6), 789-817.

Moratalla, J. J., \& Hernán, J. (2010). Probable palaeogeographic influences of the Lower Cretaceous Iberian rifting phase in the Eastern Cameros Basin (Spain) on dinosaur trackway orientations. Palaeogeography, Palaeoclimatology, Palaeoecology, 295(1-2), $116-130$.

Mountney, N. P. (2006). Aeolian Facies Models. In H. Posamentier \& R. G. Walker (Eds.), Facies Models Revisited, SEPM Special Publication 84 (pp. 19-83). SEMP: Tulsa.

Murphy, M. A., \& Salvador, A. (1999). International Stratigraphic Guide-An abridged version. Episodes, 22, 255-271.

Myers, T. S., Tabor, N. J., Jacobs, L. L., \& Mateus, O. (2012). Palaeoclimate of the Late Jurassic of Portugal: comparison with the Western United States. Sedimentology, 59(6), 1695-1717.

Olóriz, F., Valenzuela, M., García-Ramos, J. C., \& Suárez de Centi, C. (1988). The first record of the genus Eurasenia (Ammonitina) from the Upper Jurassic of Asturias (northern Spain). Geobios, 21(6), 741-748.

Ortega, F., Escaso, F., Gasulla, J. M., Dantas, P., \& Sanz, J. L. (2006). Los Dinosaurios de la Península Ibérica. Estudios Geológicos, 62(1), 219-240.

Pacios, D., Campos-Soto, S., Suarez-Gonzalez, P., Benito, M. I., Cobos, A., \& Caus, E. (2018). Revisión cartográfica y estratigráfica del Jurásico Superior-Cretácico Inferior de Villel (Teruel). Geogaceta, 63, 19-22.

Pascual, C., Canudo, J. I., Hernández, N., Barco, J. L., \& Castanera, D. (2012). First record of stegosaur dinosaur tracks in the Lower Cretaceous (Berriasian) of Europe (Oncala group, Soria, Spain). Geodiversitas, 34(2), 297-312.

Pascual-Arribas, C., \& Hernández-Medrano, N. (2015). Nuevas huellas de Estegosáuridos en el Titoniense-Berriasiense de la Cuenca de Cameros (Formación Magaña). Revista de la Sociedad Geológica de España, 28(2), 15-27.

Pascual-Arribas, C., \& Hernández-Medrano, N. (2016). Huellas de Pteraichnus en la Muela (Soria, España): consideraciones sobre el icnogénero y sobre la diversidad de huellas de pterosaurios en la Cuenca de Cameros. Revista de la Sociedad Geológica de España, 29(2), 89-105.

Pélissié, T., Peybernés, B., \& Rey, J. (1984). Les grands foraminifères benthiques du Jurassique moyen/supérieur du sud-ouest de la France (Aquitaine, Causses, Pyrénées). Intérêt biostratigraphique, paléoécologique et paléobiogógraphique. Benthos, 83(2), 479-489.

Pena dos Reis, R. P. B., Cunha, P. P., Dinis, J. L., \& Trincão, P. R. (2000). Geologic Evolution of the Lusitanian Basin (Portugal) during the Late Jurassic. GeoResearch Forum, 6, 345-356.

Pena dos Reis, R. P. B., Lamas, N., \& Vasconcelos, A. J. (2010-2011). A Bacia Lusitânica (Portugal): análise estratigráfica e evolução geodinámica. Boletin Geociencias Petrobras, 19, 23-52.

Pereda-Suberbiola, X., Galton, P. M., Ruiz-Omeñaca, J. I., \& Canudo, J. I. (2005). Dermal spines of stegosaurian dinosaurs from the Lower Cretaceous (Hauterivian-Barremian) of Galve (Teruel, Aragón, Spain). Geogaceta, 38, 35-38.

Pereda-Suberbiola, X., Ruiz-Omeñaca, J. I., \& Company, J. (2009). Primera descripción de restos esqueléticos de dinosaurio ornitópodo en la Formación Villar del Arzobispo (tránsito JurásicoCretácico): yacimiento de Cerrito del Olmo (Alpuente, Valencia). Geogaceta, 47, 13-16.

Pérez-García, A., Sánchez, B., \& Ortega, F. (2009). Aportaciones sobre José Royo y Gómez al conocimiento sobre los dinosaurios de España. Paleolusitana, 1, 339-364.

Pérez-Lorente, F., \& Herrero-Gascón, J. (2007). El movimiento de un dinosaurio deducido de una rastrillada terópoda con estructuras de inmersión de los pies en barro y de arrastre de cola (Formación Villar del Arzobispo, Galve, Teruel, España). Revista española de paleontología, 22(2), 157-174.

Peropadre, C., Meléndez, N., \& Liesa, C. L. (2012). Nuevas unidades estratigráficas del Aptiense en la cuenca del Maestrazgo (este de España). Geo-Temas, 13, 86-89.

Piñuela, L., Gacría-Ramos, J. C., Romano, M., \& Ruiz-Omeñaca, J. I. (2016). First record of gregarious behavior in robust mediumsized Jurassic ornithopods: Evidence from the Kimmeridgian trackways of Asturias (N. Spain) and some general considerations on other medium-large ornithopod tracks in the Mesozoic record. Ichnos, 23, 298-311.

Platt, N. P. (1989). Continental sedimentation in an evolving rift basin" the Lower Cretaceous of the western Cameros Basin (northern Spain). Sedimentary Geology, 64(1-3), 91-109.

Plink-Björklund, P. (2015). Morphodynamics of rivers strongly affected by monsoon precipitation: Review of depositional style and forcing factors. Sedimentary Geology, 323, 110-147.

Pujalte, V., Robles, J. C., García-Ramos, J. C., \& Hernández, J. M. (2004). El Malm-Barremiense no marinos en la Cordillera Cantábrica. In J. A. Vera (Ed.), Geología de España (pp. 288-291). Madrid: SGE-IGME.

Quijada, I. E., Suarez-Gonzalez, P., Benito, M. I., \& Mas, R. (2013). New insights on stratigraphy and sedimentology of the Oncala Group (eastern Cameros Basin): implications for the paleogeographic reconstruction of NE Iberia at Berriasian times. Journal of Iberian Geology, 39(2), 313-334.

Ramírez del Pozo, J. (1969). Bioestratigrafía y Paleogeografía del Jurásico de la costa asturiana (Zona de Oviedo-Gijón-Villaviciosa). Boletín Geológico y Minero, 80, 307-332.

Rauhut, O. W. M., Piñuela, L., Castanera, D., García-Ramos, J., \& Sánchez Cela, I. (2018). The largest European theropod dinosaurs: remains of a gigantic megalosaurid and giant theropod tracks from the Kimmeridgian of Asturias. Spain. PeerJ, 6, e4963.

Ravnås, R., Windelstad, J., Mellere, D., Nøttvedt, A., Sjøblom, T. S., Steel, R. J., et al. (1997). A marine Late Jurassic syn-rift succession in the Lusitanian Basin, western Portugal-tectonic significance of stratigraphic signature. Sedimentary Geology, 114(1-4), 237-266.

Rodríguez-López, J. P., Meléndez, N., De Boer, P. L., \& Soria, A. R. (2008). Aeolian sand sea development along the mid-Cretaceous western Tethyan margin (Spain): erg sedimentology and palaeoclimate implications. Sedimentology, 55(5), 1253-1292. 
Royo y Gómez, J. (1926). Los vertebrados del Cretácico español de facies weáldica. Boletín de la Sociedad Española de Historia Natural, 47, 171-176.

Royo y Gómez, J. (1927). Nuevos descubrimientos paleontológicos en la facies weáldica de Levante. Boletín de la Sociedad Española de Historia Natural, 27, 113-115.

Royo-Torres, R., Alcalá, L., \& Cobos, A. (2012). A new specimen of the Cretaceous sauropod Tastavinsaurus sanzi from El Castellar (Teruel, Spain), and a phylogenetic analysis of the Laurasiformes. Cretaceous Research, 34, 61-83.

Royo-Torres, R., Cobos, A., \& Alcalá, L. (2006). A Giant European Dinosaur and a New Sauropod Clade. Science, 314(5807), 1925-1927.

Royo-Torres, R., Cobos, A., Luque, L., Aberasturi, A., Espílez, E., Fierro, I., et al. (2009). High European sauropod dinosaur diversity during Jurassic-Cretaceous transition in Riodeva (Teruel, Spain). Palaeontology, 52(5), 1009-1027.

Royo-Torres, R., Upchurch, P., Kirkland, J. I., DeBlieux, D. D., Foster, J. R., Cobos, A., et al. (2017). Descendants of the Jurassic turiasaurs from Iberia found refuge in the Early Cretaceous of western USA. Scientific Reports, 7, 14311.

Royo-Torres, R., Upchurch, P., Mannion, P. D., Mas, R., Cobos, A., Gascó, F., et al. (2014). The anatomy, phylogenetic relationships, and stratigraphic position of the Tithonian-Berriasian Spanish sauropod dinosaur Aragosaurus ischiaticus. Zoological Journal of the Linnean Society, 171(3), 623-655.

Ruiz-Omeñaca, J. I., Canudo, J. L., Aurell, M., Bádenas, B., Barco, J. L., Cuenca-Bescós, C., et al. (2004). Estado de las investigaciones sobre los vertebrados del Jurásico Superior y Cretácico Inferior de Galve (Teruel). Estudios Geológicos, 60, 179-202.

Salas, R. (1987). El Malm i el Cretaci inferior entre el Massís de Garraf i la Serra D'Espada. Anàlisi de conca. Tesis Doctoral (p. 345). Barcelona: Universidad de Barcelona.

Salas, R., \& Guimerà, J. (1996). Rasgos estructurales principales de la cuenca cretácica inferior del Maestrazgo (Cordillera Ibérica oriental). Geogaceta, 20, 1704-1706.

Salas, R., \& Guimerà, J. (1997). Estructura y estratigrafía secuencial de la cuenca del Maestrazgo durante la etapa de rift jurásica superior-cretácica inferior (Cordillera Ibérica oriental). Boletín Geológico y Minero, 108(4-5), 393-402.

Salas, R., Guimerà, J., Mas, R., Martin-Closas, C., Melendez, A., \& Alonso, A. (2001). Evolution of the Mesozoic Central Iberian Rift System and its Cainozoic inversion (Iberian chain). In W., Cavazza, A. H. F. R. Roberston, P. Ziegler (Eds.), Peri-Tethyan Rift/Wrech basins and Passive Margins. (pp. 145-185). Paris: Musee National Histoire Naturelle.

Sánchez-Hernández, B. (2005). Galveosaurus herreroi, a new sauropod dinosaur from Villar del Arzobispo Formation (TithonianBerriasian) of Spain. Zootaxa, 1034(1), 1-20.

Sánchez-Hernández, B., Benton, M. J., \& Naish, D. (2007). Dinosaurs and other fossil vertebrates from the Late Jurassic and Early Cretaceous of the Galve area, NE Spain. Palaeogeography, Palaeoclimatology, Palaeoecology, 249(1-2), 180-215.

Santisteban, C. (1995). Los depósitos continentales con facies Weald de la cubeta de Aras de Alpuente. Comarca de Los Serranos. Valencia. Geogaceta, 17, 16-18.

Santisteban, C., \& Esperante, R. (2005). Estructura de un cauce encajado (Incised Valley), en materiales de la Formación Calizas, areniscas y arcillas de Villar del Arzobispo, Cuenca Ibérica Suroccidental, Valencia. Geo-Temas, 8, 109-112.

Santisteban, C., Gaete, R., Galobart, A., \& Suñer, M. (2003). Rastros de dinosaurios en el Jurásico terminal (facies Purbeck) de Corcolilla (Los Serranos, Valencia). In F. Pérez-Lorente (Ed.), Dinosaurios y otros reptiles mesozoicos de España (pp. 33-40). Logroño: Instituto de Estudios Riojanos.
Santisteban, C., \& Santos-Cubedo, A. (2010). Relación entre playas aterrazadas y cauces encajados, en depósitos deltaicos de la Formación Villar del Arzobispo (Cuenca Íbero-Levantina). In J. I. Ruiz-Omeñaca, L. Piñuela, \& J. C. García-Ramos (Eds.), Comunicaciones del V Congreso del Jurásico de España (pp. 135-141). Colunga: Museo del Jurásico de Asturias.

Santisteban, C., \& Suñer, M. (2002). Generación de estructuras de carga y pseudonódulos asociados a la impresión de icnitas de grandes vertebrados continentales, posiblemente de dinosaurios, en el Jurásico superior y Cretácico inferior de Alpuente (Valencia). Geogaceta, 32, 225-228.

Santisteban, C., Suñer, M., \& Vila, B. (2009). El yacimiento de icnitas de dinosaurios de Cañada Paris, Alpuente, Valencia. In: P. Huerta Hurtado, F. Torcida Fernández-Baldor (Eds.), Actas de las IV Jornadas Internacionales sobre Paleontología de Dinosaurios y su Entorno (pp. 301-309). Burgos: Colectivo Arqueológico y Paleontológico de Salas.

Santos, A. A., Villanueva-Amadoz, U., Royo-Torres, R., Sender, L. M., Cobos, A., Alcalá, L., et al. (2018). Palaeobotanical records associated with the first dinosaur defined in Spain: Palynostratigraphy, taxonomy and palaeoenvironmental remarks. Cretaceous Research, 90, 318-334.

Sanz, J. L., Buscalioni, A. D., Casanovas, M. L., \& Santafé, J. V. (1987). Dinosaurios del Cretácico Inferior de Galve (Teruel, España). Estudios Geológicos, 43, 45-64.

Schudack, U., \& Schudack, M. (2002). New biostratigraphical data for the Upper Jurassic of Asturias (Northern Spain) based on ostracoda. Revista Española de Micropaleontología, 34(1), 1-18.

Schudack, U., \& Schudack, M. (2009). Ostracod biostratigraphy in the Lower Cretaceous of the Iberian chain (eastern Spain). Journal of Iberian Geology, 35(2), 141-168.

Septfontaine, M., Arnaud-Vanneau, A., Bassoullet, J. P., Gušić, I., Ramalho, M., \& Velić, I. (1991). Les Foraminifères imperforés des plate-formes carbonatées jurassiques: état des connaissances et perspectives d'avenir. Bulletin de la Societé Vaudoise des Sciences naturelles, 80(3), 255-277.

Soria, A. R. (1997). La sedimentación en las cuencas marginales del Surco Ibérico durante el Cretácico Inferior y su control estructural. Tesis Doctoral (p.363). Zaragoza: Universidad de Zaragoza.

Suárez Vega, L. C. (1974). Estratigrafía del Jurásico de Asturias. Cuadernos de Geología Ibérica, 3, 1-368.

Suarez-Gonzalez, P., Quijada, I. E., Benito, M. I., \& Mas, R. (2015). Sedimentology of ancient coastal wetlands: Insights from a Cretaceous multifaceted depositional system. Journal of Sedimentary Research, 85(2), 95-117.

Suñer, M., Santisteban, C., \& Galobart, A. (2005). Nuevos restos de Theropoda del Jurásico Superior Superior-Cretácico Inferior de la Comarca de los Serranos (Valencia). Revista Española de Paleontología, N.E. X, 93-99.

Taylor, A. M., Gowland, S., Leary, S., Keogh, K. J., \& Martinius, A. W. (2014). Stratigraphical correlation of the Late Jurassic Lourinhã Formation in the Consolação Sub-basin (Lusitanian Basin). Portugal. Geological Journal, 49(2), 143-162.

Thierry, J., Abbate, E., Alekseev, A. S., Ait-Ouali, R., Ait-Salem, H., Bouaziz, S., et al. (2000a). Early Kimmeridgian. In J. Decorut, M. Gaetani, B. Vrielynck, E. Barrier, B. Biju-Duval, M. F. Brunet, J. P. Cadet, S. Crasquin, \& M. Sandulescu (Eds.), Atlas periTethys palaeogeographical maps (Map-10). Paris: CCGM.

Thierry, J., Barrier, E., Abbate, E., Alekseev, A. S., Ait-Ouali, R., AitSalem, H., et al. (2000b). Early Tithonian. In J. Decorut, M. Gaetani, B. Vrielynck, E. Barrier, B. Biju-Duval, M. F. Brunet, J. P. Cadet, S. Crasquin, \& M. Sandulescu (Eds.), Atlas peri-Tethys palaeogeographical maps (Map-11). Paris: CCGM.

Tischer, G. (1966). Über die Wealden-Ablagerung und die Tektonik der östlichen Sierra de los Cameros in den nordwestlichen Iberischen 
Ketten (Spanien). Beihefte zum Geologischen Jahrbuch, 44, 123-164.

Val, J., Aurell, M., Bádenas, B., Castanera, D., \& Subías, S. (2019). Cyclic carbonate-siliciclastic sedimentation in a shallow marine to coastal environment (latest Kimmeridgian-early Tithonian, Galve sub-basin, Spain). Journal of Iberian Geology, 45, 195-222.

Valenzuela, M., García-Ramos, J. C., \& Suárez de Centi, C. (1986). The Jurassic sedimentation in Asturias (N Spain). Trabajos de Geología, 16(16), 121-132.

Valenzuela, M., García-Ramos, J. C., \& Suárez de Centi, C. (1988). Las huellas de dinosaurios del entorno de Ribadesella (p. 34). Ribadesella: Central Lechera Asturiana.

Velic, I. (2007). Stratigraphy and palaeobiogeography of Mesozoic benthic foraminifera of the Karst Dinarides (SE Europe). Geologia Croatica, 60(1), 1-113.

Viallard, P. (1973). Reserches sur le cycle alpin dans la Chaine ibérique sud-occidentale. Tesis (p. 1445). Tolouse: Université Paul Sabatier.

Vilas, L., Arias, C., Castro, J. M., Company, M., García-Hernández, M., de Gea, G., et al. (2004). Ciclo VI. In J. A. Vera (Ed.), Geología de España (pp. 368-369). Madrid: SGE-IGME.
Vilas L., Arias C., García A. (1982b) El paso del Dominio Ibérico al Dominio Bético en la zona suroriental de Albacete. In $\mathrm{El} \mathrm{Cre-}$ tácico de la parte Oriental de la Provincia de Albacete. (pp. 47- 72). Madrid, Ed. Complutense.

Vilas L., Dabrio C. J., Peláez J.R., García Hernández M. (2001). Dominios sedimentarios generados durante el período extensional Cretácico Inferior entre Cazorla y Hellín (Béticas externas). Su implicación en la estructura actual. Revista de la Sociedad Geológica de España, 25(1-2),113-122.

Vilas, L., Mas, R., García, A., Arias, C., Alonso, A., Meléndez, N., et al. (1982a). Capítulo 8 Ibérica suroccidental. In A. García (Ed.), El Cretácico de España (pp. 457-514). Madrid: Universidad Complutense de Madrid.

Weishampel, D. B., Barret, P. M., Coria, R., Le Loeuff, J., Xing, X., Xijin, Z., et al. (2004). Dinosaur distribution. In D. B. Weishampel, P. Dodson, \& H. Osmólska (Eds.), The Dinosauria (pp. 517-606). Berkeley: University California Press.

Wilson, R. C. L. (1979). A reconnaissance study of Upper Jurassic sediments of the Lusitanian Basin. Ciências da Terra, 5, 53-84.

\section{Affiliations}

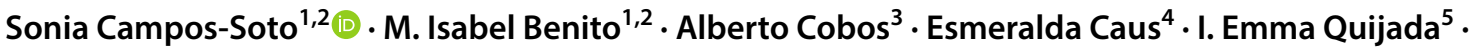 Pablo Suarez-Gonzalez ${ }^{6} \cdot$ Ramón Mas $^{1,2} \cdot$ Rafael Royo-Torres $^{3} \cdot$ Luis Alcalá $^{3}$}

\author{
M. Isabel Benito \\ mibenito@ucm.es \\ Alberto Cobos \\ cobos@dinopolis.com \\ Esmeralda Caus \\ esmeralda.caus@uab.es \\ I. Emma Quijada \\ emma@geol.uniovi.es \\ Pablo Suarez-Gonzalez \\ pablo.suarez@urjc.es \\ Ramón Mas \\ ramonmas@ucm.es \\ Rafael Royo-Torres \\ royo@dinopolis.com \\ Luis Alcalá \\ alcala@dinopolis.com
}

1 Departamento de Geodinámica, Estratigrafía y Paleontología, Facultad de Ciencias Geológicas, Universidad Complutense de Madrid, 28040 Madrid, Spain

2 Instituto de Geociencias IGEO (CSIC, UCM), C/Severo Ochoa 7, 28040 Madrid, Spain

3 Fundación Conjunto Paleontológico de Teruel-Dinópolis, Avda. Sagunto s/n, 44002 Teruel, Spain

4 Departament de Geologia (Unitat de Paleontologia), Universitat Autònoma de Barcelona, Campus Bellaterra, 08193 Cerdanyola del Vallés, Spain

5 Departamento de Geología, Universidad de Oviedo, C/Jesús Arias de Velasco s/n, 33005 Oviedo, Spain

6 Área de Geología, Universidad Rey Juan Carlos, C/Tulipán s/n, 28933 Móstoles, Spain 